\title{
Impacts of transported background pollutants on summertime western US air quality: model evaluation, sensitivity analysis and data assimilation
}

\author{
M. Huang ${ }^{1,6}$, G. R. Carmichael ${ }^{1}$, T. Chai ${ }^{2}$, R. B. Pierce ${ }^{3}$, S. J. Oltmans ${ }^{4}$, D. A. Jaffe ${ }^{5}$, K. W. Bowman ${ }^{6}$, A. Kaduwela ${ }^{7}$, \\ C. Cai ${ }^{7}$, S. N. Spak ${ }^{1,8}$, A. J. Weinheimer ${ }^{9}$, L. G. Huey ${ }^{10}$, and G. S. Diskin ${ }^{11}$ \\ ${ }^{1}$ Center for Global and Regional Environmental Research, University of Iowa, Iowa City, IA 52242, USA \\ ${ }^{2}$ NOAA/OAR/ARL, College Park, MD 20740, USA \\ ${ }^{3}$ NOAA/NESDIS, Madison, WI 53706, USA \\ ${ }^{4}$ NOAA/ESRL, Boulder, CO 80305, USA \\ ${ }^{5}$ University of Washington, Bothell, WA 98011, USA \\ ${ }^{6}$ Jet Propulsion Laboratory, California Institute of Technology, Pasadena, CA 91109, USA \\ ${ }^{7}$ California Air Resources Board, Sacramento, CA 95812, USA \\ ${ }^{8}$ Public Policy Center, University of Iowa, Iowa City, IA 52242, USA \\ ${ }^{9}$ National Center for Atmospheric Research, Boulder, CO 80305, USA \\ ${ }^{10}$ School of Earth and Atmospheric Sciences, Georgia Institute of Technology, Atlanta, GA 30332, USA \\ ${ }^{11}$ NASA Langley Research Center, Hampton, VA 23681, USA
}

Correspondence to: M. Huang (mhuang1@engineering.uiowa.edu)

Received: 17 April 2012 - Published in Atmos. Chem. Phys. Discuss.: 15 June 2012

Revised: 19 December 2012 - Accepted: 19 December 2012 - Published: 14 January 2013

\begin{abstract}
The impacts of transported background (TBG) pollutants on western US ozone $\left(\mathrm{O}_{3}\right)$ distributions in summer 2008 are studied using the multi-scale Sulfur Transport and dEposition Modeling system. Forward sensitivity simulations show that TBG contributes $\sim 30-35 \mathrm{ppb}$ to the surface Monthly mean Daily maximum 8-h Average $\mathrm{O}_{3}$ (MDA8) over Pacific Southwest (US Environmental Protection Agency (EPA) Region 9, including California, Nevada and Arizona) and Pacific Northwest (EPA Region 10, including Washington, Oregon and Idaho), and 10-17 ppm$\mathrm{h}$ to the secondary standard metric "W126 monthly index" over EPA Region 9 and $~ 3-4$ ppm-h over Region 10. The strongest TBG impacts on W126 occur over the grass/shrubcovered regions. Among TBG pollutants, $\mathrm{O}_{3}$ is the major contributor to surface $\mathrm{O}_{3}$, while peroxyacetyl nitrate is the most important $\mathrm{O}_{3}$ precursor species. W126 shows larger responses than MDA8 to perturbations in TBG and stronger non-linearity to the magnitude of perturbations. The TBG impacts on both metrics overall negatively correlate to model
\end{abstract}

vertical resolution and positively correlate to the horizontal resolution.

The mechanisms that determine TBG contributions and their variation are analyzed using trajectories and the receptor-based adjoint sensitivity analysis, which demonstrate the connection between the surface $\mathrm{O}_{3}$ and $\mathrm{O}_{3}$ aloft (at $\sim 1-4 \mathrm{~km}$ ) 1-2 days earlier. The probabilities of airmasses originating from Mt. Bachelor $(2.7 \mathrm{~km})$ and $2.5 \mathrm{~km}$ above Trinidad Head (THD) entraining into the boundary layer reach daily maxima of $66 \%$ and $34 \%$ at $\sim 03: 00$ p.m. Pacific Daylight Time (PDT), respectively, and stay above $50 \%$ during 09:00 a.m.-04:00 p.m. PDT for those originating $1.5 \mathrm{~km}$ above California's South Coast.

Assimilation of the surface in-situ measurements significantly reduced the errors in the modeled surface $\mathrm{O}_{3}$ during a long-range transport episode by $\sim 5 \mathrm{ppb}$ on average (up to $\sim 17 \mathrm{ppb}$ ) and increased the estimated TBG contributions by $\sim 3$ ppb. Available $\mathrm{O}_{3}$ vertical profiles from Tropospheric Emission Spectrometer (TES), Ozone Monitoring Instrument (OMI) and THD sonde identified this transport 
event, but assimilation of these observations in this case did not efficiently improve the $\mathrm{O}_{3}$ distributions except near the sampling locations, due to their limited spatiotemporal resolution and/or possible uncertainties.

\section{Introduction}

Transported background (TBG) ozone $\left(\mathrm{O}_{3}\right)$ and its precursors from the eastern Pacific and the lower stratosphere, together with the locally-formed $\mathrm{O}_{3}$ from anthropogenic and natural (e.g., biogenic/geogenic, lightning and biomass burning) emissions, affect the $\mathrm{O}_{3}$ variability over the western United States (US). The contribution from TBG indicates the strength of influences from extra-regional emission sources and the stratospheric $\mathrm{O}_{3}$, and accounts for a significant part of the background $\mathrm{O}_{3}$, defined as the concentration that is not affected by recent locally-emitted/produced anthropogenic emissions. The magnitude of TBG is expected to increase as the international emission sources grow (Task Force on Hemispheric Transport of Air Pollution (HTAP), 2010; National Research Council (NRC), 2009; Cooper et al., 2012). This trend is especially important in the context of US air quality standards, which tend to be tightened over time to further protect human health and ecosystems. The US Environmental Protection Agency (EPA) proposed to lower the federal 8-h primary $\mathrm{O}_{3}$ standard to a level within $60-70 \mathrm{ppb}$, and to establish a seasonal "secondary" standard to protect sensitive vegetation and ecosystems, in the form of "cumulative peak-weighted index" (W126) within 7-15 ppm-h (US EPA, 2010). The proposal was withdrawn in 2011 and the next revision is expected to occur in 2013 based on the most recent scientific findings (The White House Office of the Press Secretary, 2011).

Observational and modeling studies have been conducted to evaluate the impacts of extra-regional sources on western North America (NA) $\mathrm{O}_{3}$ variability and to estimate the background $\mathrm{O}_{3}$ levels. They have shown that trans-Pacific transport episodes are frequent and intense during the spring time (Cooper et al., 2010; HTAP, 2010). There is growing recognition that the extra-regional contributions in summer are also important (Bertschi et al., 2004; Jaffe et al., 2004; Parrish et al., 2010; Pfister et al., 2008, 2011a,b; Huang et al., 2010a). In addition to impacts of $\mathrm{TBG} \mathrm{O}_{3}$ itself, $\mathrm{O}_{3}$ precursors (e.g., peroxyacetyl nitrate (PAN)) in the extra-regional plumes can generate $\mathrm{O}_{3}$ during the transport and subsidence processes (Alvarado et al., 2010; Zhang et al., 2008; Fischer et al., 2010, 2011; Mena-Carrasco et al., 2007; Walker et al., 2010).

Observations over three dimensions are available to characterize pollution distributions and their evolution, and the capabilities for observational-based estimates of extraregional/TBG influences are also increasing (Ambrose et al., 2011; Cooper et al., 2011; Parrish et al., 2009; Langford et al., 2011; Wigder et al., 2012). These include: surface obser- vations from monitoring programs and research sites at remote locations which provide valuable information for identifying inflow characteristics; aircraft in-situ measurements and sondes, which provide information on pollutant vertical structures and can be extensive during field campaigns; and satellite measurements that routinely provide broad geographic coverage, and which are taking efforts to improve the near-surface sensitivity of the retrievals (e.g., combined retrieval of the ultraviolet (UV), infrared (IR) and visible (Vis) spectral ranges, Worden et al., 2007; Zoogman et al., 2011; Fu et al., 2012), and to better characterize/represent the upper troposphere vertical structures (Moody et al., 2012).

To date, most of the modeling studies that estimate background $\mathrm{O}_{3}$ levels and the contributions from extra-regional sources to US pollution levels have used global models with horizontal resolution ranging from several degrees to $\sim$ half degree, and they typically perturb emissions from various source regions/sectors by $20 \%$ or $100 \%$ (HTAP, 2010; Zhang et al., 2011; Lin et al., 2012a). However, there remain large uncertainties in these estimates. One source of uncertainty derives from the model resolution. The advantages of using finer model resolution in representing the pollutant import/export processes have been demonstrated (Lin et al., 2010; Wild and Prather, 2006), especially over urban areas and the regions with complex terrain. Increasing model horizontal resolution may result in higher estimates of extraregional contributions to the western US (Zhang et al., 2011; Lin et al., 2012a). Model vertical resolution is also critical for representing boundary layer structure and vertical mixing, key processes associated with inflow subsidence (Saide et al., 2011). The impacts of model vertical resolution on the sensitivity of $\mathrm{NA} \mathrm{O}_{3}$ distributions to extra-regional pollutants have not been well characterized. Another source of uncertainty is that due to the extrapolation of emission perturbation results to estimate source attribution. Using global models, Fiore et al. (2009) and Wild et al. (2012) have studied the contribution from European $\mathrm{NO}_{\mathrm{x}}$ emissions to $\mathrm{NA} \mathrm{O}_{3}$ levels and found that the estimates that were linearly extrapolated from $20 \%$ perturbations were lower than those based on $100 \%$ perturbations, and the extent of the differences depended on season. A better understanding of the non-linear effects of NA surface $\mathrm{O}_{3}$ in response to perturbations of various species in extra-regional plumes is needed, especially in light of the fact that future emission scenarios indicate a wide range of possible emission changes.

Reducing the uncertainties in modeling pollutant distributions and estimating the contributions of extra-regional sources to local air quality require a closer integration of the observations and models. Sensitivity analysis and data assimilation (DA) ( $c f$, Bouttier and Courtier, 1999; Carmichael et al., 2008; Sandu and Chai, 2011) are important techniques to: (1) help understand the chemical and physical processes associated with the transport/subsidence processes; (2) assess the degree to which the current observations can detect/represent long-range transport (LRT) airmasses and help 
reduce model uncertainties; and (3) provide suggestions for future observing systems, such as measurements by extended $\mathrm{O}_{3}$ sonde networks, regional airlines, and geostationary satellites that are expected to have higher spatiotemporal resolution (Committee on Earth Observation Satellites (CEOS), 2011; Geostationary Coastal and Air Pollution Events (GEOCAPE), http://geo-cape.larc.nasa.gov).

In this paper, the regional scale Sulfur Transport and dEposition Model (STEM) is used to address the issues raised above. Specifically we study the impacts of TBG pollutants on western US surface $\mathrm{O}_{3}$ during summer (mid-June to midJuly) 2008 when the Arctic Research of the Composition of the Troposphere from Aircraft and Satellites (ARCTAS) field campaign was conducted (http://www.espo.nasa.gov/ arctas/) by National Aeronautics and Space Administration (NASA). This study extends the analysis period in Huang et al. (2010a), which focused exclusively on $\mathrm{O}_{3}$ during a $\sim$ oneweek period over California (CA), and expands the study domain to the western US. For this region, we estimate the contributions of various TBG pollutants to two policy-relevant $\mathrm{O}_{3}$ metrics over different geographical locations and land types. We also compare the bias-corrected TBG contributions with those from other contributors to background $\mathrm{O}_{3}$ (Sect. 3.1). We then evaluate the effects of model resolution and NA anthropogenic emissions on the uncertainties in estimated TBG contributions (Sect. 3.2). To better understand the mechanisms that determine the TBG contributions and their variation, we analyze in detail the sources of $\mathrm{O}_{3}$ at three selected sites, and how the surface $\mathrm{O}_{3}$ levels are connected to the airmasses aloft at these sites (Sect. 3.3). Finally, we investigate the effectiveness of currently available $\mathrm{O}_{3}$ observations in identifying a LRT episode and reducing the errors in modeled total $\mathrm{O}_{3}$ and the estimated TBG contributions (Sect. 3.4).

\section{Data and methods}

\subsection{Study period, meteorological conditions and fire activities}

The study period spans from 16 June to 14 July, 2008, during which the NASA ARCTAS-CARB and ARCTAS-B field experiments were conducted (Jacob et al., 2010).

Climatologically, the central and eastern Pacific during summertime is dominated by a surface high-pressure system, while Asia and the western Pacific experience a lowpressure system associated with the seasonal monsoon. Fuelberg et al. (2010) generalized synoptic conditions during 18 June-13 July, 2008, and found no major departures from climatology. Cyclones were frequent and intense, mostly forming over Northern Russia and Canada, but had little impact on CA. The jet stream at $300 \mathrm{hPa}$ was located over central China (close to climatology) and northern Asia (with strong positive anomaly).
Fire activity was overall high during summer 2008 over CA, Canada, and Eurasia. Rapid PAN conversion from fireemitted $\mathrm{NO}_{\mathrm{x}}$ was indicated, and the lifting of emissions above the boundary layer due to buoyancy led to LRT events (Jacob et al., 2010). LRT and NA fire plumes were frequently sampled by the DC-8 aircraft (http://www.espo.nasa. gov/arctas/flightDocs.php) during ARCTAS. Compared with previous years fire records (Table S1), the 2008 Siberia fire counts and total radiative power were higher, but with a lower value of radiative power per plume (RPPP) than those in 2002-2003 (Bertschi et al., 2004 and Jaffe et al., 2004 showed the strong impacts of summer 2003 Siberia fires on northwestern US air quality).

A record lack of rainfall, severely dry vegetation and uncharacteristically windy weather combined to cause the strong fire activity over CA and Oregon (OR), the majority of which started from 20-21 June due to lightning and dry thunderstorms over northern and central CA. The areas burned in 2008 (1 593690 acres) far exceeded previous years (2003-2007 average: 757986 acres, http://www.fire.ca.gov/downloads/ redbooks/2008/02-wildland-statistic-all-agencies/

11-2008-FIRE-SUMMARY.pdf). Fires can result in $\mathrm{O}_{3}$ enhancements, which can be intensified when interacting with urban smog over CA (Singh et al., 2012).

\subsection{Observation data}

The observations used as model inputs and to evaluate/improve the model performance are summarized in Table 1. They include:

1. Surface $\mathrm{O}_{3}$ measurements: Hourly $\mathrm{O}_{3}$ at all US EPA Air Quality System (AQS) and Clean Air Status and Trends Network (CASTNET) sites in CA, OR, Nevada (NV), Washington (WA) and Idaho (ID) (multiple measurement methods described in Table 1); and hourly $\mathrm{O}_{3}$ measurements by UV Photometric Ozone Analyzer at Mt. Bachelor Observatory (MBO, topography $\sim 2.7 \mathrm{~km}$ a.s.l.). This high-altitude site has been demonstrated to represent LRT of pollution into the northwestern US (e.g., Fischer et al., 2010, 2011; Weiss-Penzias et al., 2007; Ambrose et al., 2011);

2. Ozone sondes: Twenty $\mathrm{O}_{3}$ sondes launched ( 8 in June, 12 in July) at Trinidad Head (THD, 20 ma.s.1.), mostly at $\sim$ 19:00-22:00 UTC (noon-03:00 p.m. Pacific Daylight Time (PDT)) in support of ARCTAS. THD is a coastal remote air quality measurement site located in northern CA, which is thought to well represent the properties of airmasses entering the US (Oltmans et al., 2008);

3. Aircraft measurements: $\mathrm{CO}, \mathrm{O}_{3}$, total oxides of nitrogen $\left(\mathrm{NO}_{\mathrm{y}}\right)$, and PAN sampled on the 22 June DC8 flight off shore of CA were used to evaluate the 
Table 1. Description of observational datasets used in this study.

\begin{tabular}{|c|c|c|c|c|}
\hline Observational data & Location & $\begin{array}{l}\text { Dates of the observa- } \\
\text { tions }\end{array}$ & $\begin{array}{l}\text { Spatiotemporal } \\
\text { resolution }\end{array}$ & Method \\
\hline Ground $\mathrm{O}_{3}^{\mathrm{a}}$ & $\begin{array}{l}\text { U.S. EPA AQS sites in CA, NV, } \\
\text { OR, WA, and ID }\end{array}$ & 16 June-14 July & $1 \mathrm{~h}$ & $\begin{array}{l}\text { Multiple methods: UV; UV ab- } \\
\text { sorption; UV radiation absorp- } \\
\text { tion; UV 2B Model } 202\end{array}$ \\
\hline Ground $\mathrm{O}_{3}^{\mathrm{b}}$ & $\begin{array}{l}\text { Eight CASTNET sites in CA, } \\
\mathrm{NV}, \mathrm{OR} \text {, WA, and ID }\end{array}$ & 16 June-14 July & $1 \mathrm{~h}$ & UV absorbance \\
\hline Site $\mathrm{O}_{3}$ & $\begin{array}{l}\operatorname{MBO}\left(44^{\circ} \mathrm{N},-121.7^{\circ} \mathrm{W},\right. \\
\sim 2.7 \mathrm{~km} \text { a.s.1. })\end{array}$ & 16 June-14 July & $1 \mathrm{~h}$ & $\begin{array}{l}\text { Ultraviolet (UV) Photometric } \\
\text { Ozone Analyzer }\end{array}$ \\
\hline $\mathrm{O}_{3}$ sondes ${ }^{\mathrm{c}}$ & $\begin{array}{l}\text { THD }\left(40.8^{\circ} \mathrm{N}, \quad-124.2^{\circ} \mathrm{W},\right. \\
\sim 20 \mathrm{~m} \text { a.s.1. })\end{array}$ & 20 June-12 July & $\begin{array}{l}\text { mostly } \sim 19: 00 \text { UTC, } \\
20 \text { days }\end{array}$ & $\begin{array}{l}\text { Electrochemical detection } \\
\text { methods through the reaction } \\
\text { of } \mathrm{O}_{3} \text { in an aqueous potassium } \\
\text { iodide solution in an electro- } \\
\text { chemical cell }\end{array}$ \\
\hline DC- $8 \mathrm{CO}^{\mathrm{d}}$ & $\begin{array}{l}\text { Eastern Pacific (flight track in } \\
\text { Fig. 1g) }\end{array}$ & 22 June & $\begin{array}{l}1 \min (\text { DC-8 speed: } \\
\left.\sim 14 \mathrm{~km} \mathrm{~min}^{-1}\right)\end{array}$ & Diode laser spectrometer \\
\hline $\mathrm{DC}-8 \mathrm{O}_{3} \& \mathrm{NO}_{\mathrm{y}}^{\mathrm{d} ; \mathrm{e}}$ & & & & $\begin{array}{l}\text { NCAR 4-channel chemilumi- } \\
\text { nescence instrument }\end{array}$ \\
\hline DC-8 PAN ${ }^{\mathrm{d}}$ & & & & $\begin{array}{l}\text { CIMS Instrument by Georgia } \\
\text { Tech and NCAR }\end{array}$ \\
\hline $\begin{array}{l}\text { TES Level } 3 \text { tropospheric } \mathrm{O}_{3} \\
\text { columns and CO columns }\end{array}$ & Northern Hemisphere & 30 June and 2, 4, 6 July & $\begin{array}{l}\text { every other day, } \\
2^{\circ} \times 4^{\circ}\end{array}$ & $\begin{array}{l}\text { Measures the infrared-light en- } \\
\text { ergy (radiance) emitted } \\
\text { by Earth's surface and by } \\
\text { gases and particles in Earth's } \\
\text { atmosphere }\end{array}$ \\
\hline $\begin{array}{l}\text { TES Level } 2 \text { special observa- } \\
\text { tion nadir } \mathrm{O}_{3} \text { profiles, } \mathrm{V} 004{ }^{\mathrm{f}}\end{array}$ & $\begin{array}{l}\text { Eastern Pacific } \\
\left(150-120^{\circ} \mathrm{W}, 30-60^{\circ} \mathrm{N}\right)\end{array}$ & $\begin{array}{l}16 \text { June-14 July when } \\
\text { available }\end{array}$ & $\begin{array}{l}\text { See sampling density } \\
\text { plot in Fig. } 1 \mathrm{~g}\end{array}$ & \\
\hline $\begin{array}{l}\text { OMI Level } 2 \mathrm{O}_{3} \text { profiles, } \\
\text { V003 }\end{array}$ & Eastern Pacific and western US & 5 July & Daily & $\begin{array}{l}\text { Observes Earth's backscattered } \\
\text { radiation (in the UV) }\end{array}$ \\
\hline $\begin{array}{l}\text { OMI total } \mathrm{O}_{3} \text { columns (re- } \\
\text { quired by the TUV module) }\end{array}$ & Model domain wide & 16 June-14 July & Daily, $1^{\circ} \times 1^{\circ}$ & \\
\hline $\begin{array}{l}\text { MODIS (Terra, MOD06_L2) } \\
\text { Level } 2 \text { cloud product }{ }^{i}\end{array}$ & Eastern Pacific & 5 July & $\begin{array}{l}\text { Several times each day, } \\
\text { we used the one at } \\
\sim 20: 00 \text { UTC }\end{array}$ & $\begin{array}{l}\text { Combines infrared and visible } \\
\text { techniques to determine cloud } \\
\text { physical and radiative proper- } \\
\text { ties }\end{array}$ \\
\hline $\begin{array}{l}\text { MODIS-detected point fire in- } \\
\text { formation } \mathrm{j}\end{array}$ & Model domain wide & 16 June-14 July & $\begin{array}{l}\text { Several times each day, } \\
1 \mathrm{~km}\end{array}$ & $\begin{array}{l}\text { Multi-spectral detection of fire } \\
\text { locations }\end{array}$ \\
\hline
\end{tabular}

Data sources and descriptions

a http://www.epa.gov/ttn/airs/airsaqs/detaildata/downloadaqsdata.htm

${ }^{b}$ http://java.epa.gov/castnet/epa_ jsp/prepackageddata.jsp\#ozone

c ftp://ftp.cmdl.noaa.gov/ozwv/ozone/

d ftp://ftp-air.larc.nasa.gov/pub/ARCTAS/DC8_ AIRCRAFT/

e http://www.espo.nasa.gov/arctas/docs/instruments/NOxyO3.pdf

${ }^{\mathrm{f}}$ http://eosweb.larc.nasa.gov/PRODOCS/tes/table_tes.html

$\mathrm{g}_{\mathrm{http}} / /$ disc.sci.gsfc.nasa.gov/Aura/data-holdings/OMI/omo3pr_v003.shtml

h ftp://toms.gsfc.nasa.gov/pub/omi/data/ozone/Y2008/

${ }^{\mathrm{i}} \mathrm{http} / / /$ ladsweb.nascom.nasa.gov/data/search.html

$\mathrm{j}$ http://firefly.geog.umd.edu/download/

Abbreviations

AQS: Air Quality System; a.s.l: Above Sea Level; CASTNET: The Clean Air Status and Trends Network; CIMS: Chemical Ionization Mass Spectrometer; EPA: Environmental Protection Agency; MODIS: Moderate Resolution Imaging Spectroradiometer; NCAR: National Center for Atmospheric Research; OMI: Ozone Monitoring Instrument; TES:

Tropospheric Emission Spectrometer; TUV: Tropospheric Ultraviolet-Visible radiation model; UV: Ultraviolet

model boundary conditions (BCs), which were perturbed in the forward sensitivity simulations as described in Sect. 2.3.2; and

4. Satellite products: Measurements from the Tropospheric Emission Spectrometer (TES) and Ozone Monitoring Instrument (OMI), both on board the NASA Aura satellite, which has an ascending equator crossing time of $\sim 13: 45$ local time were used. TES Level 3 carbon monoxide $(\mathrm{CO})$ and tropospheric $\mathrm{O}_{3}$ columns on multiple days were used to locate the movement of transported pollutants from Asia to the western US, and the Level 2 V004 nadir $\mathrm{O}_{3}$ vertical profiles from special observations (in the "step-and-stare" mode where the separation between observations is $\sim 35 \mathrm{~km}$ along the orbit, Beer, 2006) were used for evaluating the model performance over the eastern Pacific and for DA on 5 July. TES Level 2 data does not have the capability 
of resolving the boundary layer $\mathrm{O}_{3}$ distribution except in summertime when there is strong thermal contrast between ground and air, and has $\sim 5-15 \%$ positive biases over LIDAR and sonde profiles (Nassar et al., 2008; Richards et al., 2008; Boxe et al., 2010); OMI Level $2 \mathrm{~V} 003 \mathrm{O}_{3}$ vertical profiles where cloud fraction $=0$ (selected by Moderate Resolution Imaging Spectroradiometer (MODIS) MOD06_L2 cloud products (Platnick et al., 2003) as suggested by Russell et al., 2011) were also assimilated on 5 July. The OMI vertical profiles have larger horizontal coverage but much lower vertical resolution than TES, showing overall positive biases ranging from $<10 \%$ to $\sim 30 \%$ for midlatitude regions, with lower sensitivity at lower and upper troposphere (Wang et al., 2011; Kroon et al., 2011; Veefkind et al., 2009); Daily total $\mathrm{O}_{3}$ columns from OMI were used in the online Tropospheric UltravioletVisible (TUV) radiation model (Madronich, 2002) to generate the photolysis rates for STEM.

\subsection{STEM model experiments and input data}

We simulated the study period using the full-chemistry version of STEM (2K3) modeling system, including its forward and adjoint versions, which have been used and evaluated in a number of field campaigns in the past decade (e.g., Carmichael et al., 2003a, b; Tang et al., 2004, 2007; Adhikary et al., 2010; Stith et al., 2009). The full-chemistry version of STEM calculates gas-phase chemistry reactions based on the SAPRC 99 gaseous chemical mechanism (Carter, 2000) with thirty photolysis rates calculated online by the TUV model.

A set of simulations were performed using a continental scale $60 \times 60 \mathrm{~km}$ polar stereographic grid with 18 vertical layers in the troposphere. The re-analyzed tropopause (http://www.esrl.noaa.gov/psd/data/gridded/data.ncep.

reanalysis.tropopause.html) for this study period ranged from $120-220 \mathrm{hPa}$, increasing with latitude. The STEM model top is placed at $\sim 170-210 \mathrm{hPa}$. These simulations were analyzed to characterize the general picture of pollutant distributions over the eastern Pacific and continental US. A set of simulations were also conducted using a $12 \mathrm{~km} \times$ $12 \mathrm{~km}$ Lambert conformal conic grid over the western US, with 32 vertical layers in the troposphere. They were used to study in greater detail the processes that link the airmasses aloft to the surface. The 18 layer grid had $\sim 7$ layers below $1 \mathrm{~km}$ and $\sim 10-11$ layers below $4 \mathrm{~km}$. The 32 layer grid had $\sim 11$ layers below $1 \mathrm{~km}$ and $\sim 20-21$ layers below $4 \mathrm{~km}$.

\subsubsection{Model inputs}

We conducted base simulations in both the $60 \mathrm{~km}$ and $12 \mathrm{~km}$ grids ( $\mathrm{C} 0$ and $\mathrm{F} 0$ in Table 2, respectively). Meteorology fields for both grids were generated by the Advanced Research Weather Research \& Forecasting Model (WRF-ARW) (Skamarock et al., 2008), driven by Global Forecast System and North American Regional Reanalysis data (Mesinger et al.,
2006), respectively. The same physics options were used as in Huang et al. (2010a). In the $60 \mathrm{~km} / 18$ layer base case $\mathrm{C} 0$, lateral boundary conditions (LBCs) for thirty gaseous species and top boundary conditions (TBCs) for ten gaseous species $\left(\mathrm{O}_{3}, \mathrm{CO}, \mathrm{NO}, \mathrm{NO}_{2}, \mathrm{NO}_{3}, \mathrm{HNO}_{3}, \mathrm{HNO}_{4}, \mathrm{PAN}, \mathrm{N}_{2} \mathrm{O}_{5}\right.$, and $\left.\mathrm{H}_{2} \mathrm{O}_{2}\right)$ were downscaled from archived $\left(2^{\circ} \times 2^{\circ}\right.$ horizontal and 6-h temporal resolution) Real-time Air Quality Modeling System (RAQMS) (Pierce et al., 2007) global real-time chemical analyses which assimilated the $\mathrm{OMI} \mathrm{O}_{3}$ columns and Microwave Limb Sounder (MLS) stratospheric $\mathrm{O}_{3}$ profiles. The $60 \mathrm{~km} \mathrm{LBCs}$ for black carbon, organic carbon, dust, sea salt and sulfate were taken from the $60 \mathrm{~km}$ hemispheric tracer results (Huang et al., 2012). The $12 \mathrm{~km}$ BCs came from the $60 \mathrm{~km}$ STEM full-chemistry simulations for both gas and aerosol species.

Since time-varying BCs downscaled from results in a coarser grid may significantly affect the regional model results (Tang et al., 2007; Huang et al., 2010a; Pfister et al., 2011a), we evaluated the BCs used in this study by comparing RAQMS and $60 \mathrm{~km}$ STEM results with: (1) $\mathrm{O}_{3}, \mathrm{CO}$, PAN and $\mathrm{NO}_{\mathrm{y}}$ sampled by the 22 June DC- 8 flight over the eastern Pacific, and (2) TES nadir $\mathrm{O}_{3}$ vertical profiles for the days that "step and stare" observations were available over the eastern Pacific (150-120 $\left.\mathrm{W}, 30-60^{\circ} \mathrm{N}\right)$ (Fig. 1). Unlike the flight-observed vertical structures over the terrestrial polluted regions such as southern CA (Huang et al., 2011) and the Central Valley, the elevated concentrations for these species over the eastern Pacific are seen in the middle and upper troposphere. The RAQMS-modeled $\mathrm{PAN}, \mathrm{NO}_{\mathrm{y}}$, and $\mathrm{O}_{3}$ agree well with the aircraft observations, with slight overprediction $<4 \mathrm{~km}$, while CO shows $40-50$ ppb bias below $4 \mathrm{~km}$, and low variability at higher altitudes. The $60 \mathrm{~km}$ STEM simulations are similar to RAQMS with slight improvement (e.g., for $\mathrm{NO}_{\mathrm{y}}$ below $4 \mathrm{~km}$ ). Both mean RAQMS and STEM $60 \mathrm{~km}$ $\mathrm{O}_{3}$ profiles (with the TES observation operator (Sect. 2.4) applied) generally show good agreement with the TES retrieval.

Anthropogenic emissions in the $60 \mathrm{~km}$ simulations were taken from the 2001 National Emissions Estimate Version 3 (NEI 2001), an update of the 1999 US National Emissions Inventory with growth factors applied by source classification code, and augmented with national inventories for Canada (2000) and Mexico (1999). Biogenic emissions of monoterpene and isoprene were from twelve-year-averaged values from the Orchidee model (Lathiere et al., 2006). Daily biomass burning emissions were provided by RAQMS (the Cooperative Institute for Meteorological Satellite Studies). The total emissions were then unevenly distributed vertically from the surface to $\sim 4-5 \mathrm{~km}$ with nonlinear factors decreasing from 0.12 to 0.013 as the model height increased (Adhikary et al., 2010). For the $12 \mathrm{~km}$ simulations over CA and during the ARCTAS-CARB mission period, we used dailyvarying anthropogenic and biogenic emissions re-gridded from a recent California Air Resources Board (CARB) $4 \mathrm{~km}$ emission inventory (received in July 2009, by personal contact with A. Kaduwela and C. Cai in CARB). For the time 
Observed vs. Modeled along DC-8 flight (Jun 22 outbound)
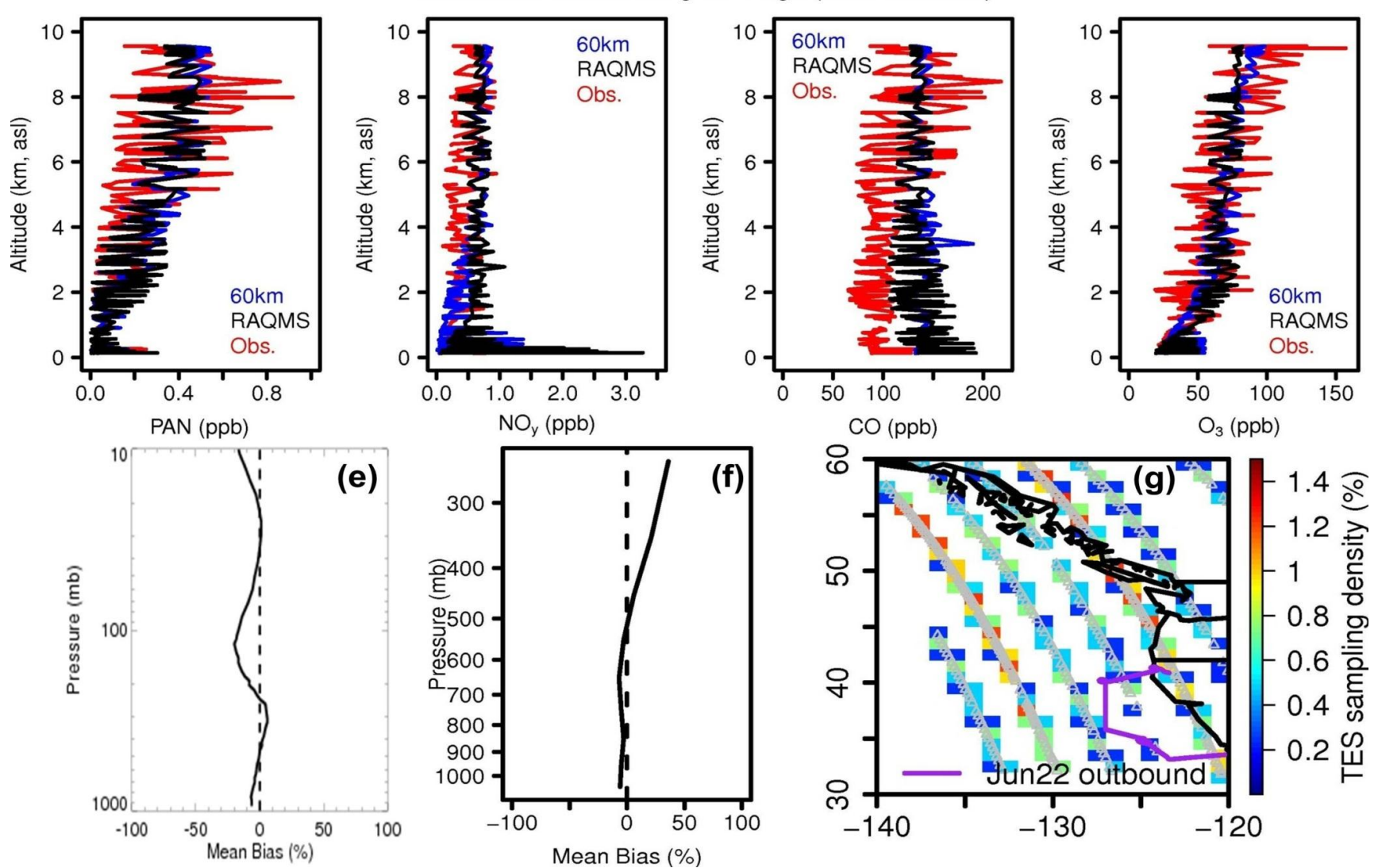

Fig. 1. Observed and modeled (RAQMS and STEM $60 \mathrm{~km}$ ) vertical profiles along the outbound part of the 22 June DC-8 flight, for (a) PAN; (b) $\mathrm{NO}_{\mathrm{y}}$; (c) CO; and (d) $\mathrm{O}_{3}$. Comparison between TES and (e) RAQMS and (f) STEM $60 \mathrm{~km}$ modeled $\mathrm{O}_{3}$ over the eastern Pacific. TES observational operator was applied. (g) TES special observation sampling density in the compared domain for STEM. Sampling density $=$ number of samples in each $1^{\circ} \times 1^{\circ} /$ total number of samples. The outbound part of the 22 June DC- 8 flight path is shown as purple line.

period outside of the ARCTAS-CARB mission, we used the averaged CARB emissions without daily variation. Anthropogenic and biogenic emissions outside of the CARB domain were same as those used in $60 \mathrm{~km}$. Biomass burning total emissions were generated with PREP-CHEM-SRC (Freitas et al., 2011) by processing the MODIS-detected point fire information at $1 \mathrm{~km}$ ground resolution (Giglio et al., 2003; Davies et al., 2009). The total emissions were then unevenly distributed from surface to $\sim 1.5-2 \mathrm{~km}$, with the same nonlinear curve used in the $60 \mathrm{~km}$. The injection heights were closer to the analyzed satellite (i.e., Multi-angle Imaging SpectroRadiometer (MISR)) wildfire plume injection heights during previous years over various regions, Table $\mathrm{S} 1$ ).

\subsubsection{Forward sensitivity simulations}

Eleven forward sensitivity simulations (Table 2, Cases C1C11) were conducted in the $60 \mathrm{~km} / 18$ layer grid to study the TBG impacts on $\mathrm{O}_{3}$ distributions. To estimate the effects of the UTLS airmasses, the $\mathrm{O}_{3}$ concentrations at the
TBC were perturbed by $50 \%$ in Case $\mathrm{C} 1$. Three simulations (Cases C2-C4) were conducted to study the surface $\mathrm{O}_{3}$ response curve to perturbations in $\mathrm{BCs}$, where $\mathrm{O}_{3}$ concentrations at both TBC and LBC were reduced by $75 \%, 50 \%$, and $25 \%$, respectively. To investigate the influence of TBG precursor species, another three simulations were performed in which eight non- $\mathrm{O}_{3}$ species $\left(\mathrm{CO}, \mathrm{NO}, \mathrm{NO}_{2}, \mathrm{NO}_{3}, \mathrm{HNO}_{3}\right.$, $\mathrm{HNO}_{4}, \mathrm{PAN}$, and $\mathrm{N}_{2} \mathrm{O}_{5}$ ) in the LBCs and TBCs were perturbed by $75 \%, 50 \%$, and $25 \%$, respectively (Cases C5C7). With specific interest in the impacts of TBG PAN on $\mathrm{O}_{3}$ levels, two simulations with PAN in TBC and LBC reduced by $50 \%$ and $25 \%$ were conducted (Cases C8-C9). In addition, PAN chemistry was partially (Case $\mathrm{C} 10)$ and completely (Case C11) blocked in separate simulations, and the differences in PAN and $\mathrm{O}_{3}$ levels between these two cases represent the amounts of decomposed transported PAN, and its contributions to $\mathrm{O}_{3}$.

Forward sensitivity simulations with $\mathrm{TBC}$ and $\mathrm{LBC} \mathrm{O}_{3}$ perturbed by $50 \%$ were also conducted: (1) under scaled US anthropogenic emissions (Case CR1) to compare with 
the sensitivities generated between Cases $\mathrm{C} 0$ and $\mathrm{C} 3$ in the $60 \mathrm{~km} / 18$ layer grid; and (2) in a $60 \mathrm{~km} / 32$ layer (Cases CL0/CL1) and the $12 \mathrm{~km}$ (Cases F0/F1) configurations to discuss the impacts of model resolution on the sensitivities.

Biomass burning and biogenic emissions were turned off in two additional emission sensitivity simulations (Cases $\mathrm{CBB}$ and $\mathrm{CBG}$ ) to compare their contributions to background $\mathrm{O}_{3}$ with the TBG at surface and selected sites (Sects. 3.1.4 and 3.3.2).

\subsubsection{Four-dimensional variational (4D-Var) DA and adjoint sensitivity analysis}

The performance of contemporary models is highly dependent on parameterizations, the quality of model inputs (e.g., emissions and meteorological fields), chemical mechanisms, and resolution (Stevenson et al., 2006; Shindell et al., 2006; Fiore et al., 2009; McKeen et al., 2009; Wild et al., 2012). Accurately modeling of air pollutants distributions still remains a challenge, especially for $\mathrm{O}_{3}$ which is involved in complex chemical processes. DA is an efficient mathematical method to improve the model performance by integrating observations, and the 4D-Var method has shown moderate/strong capabilities of improving modeled $\mathrm{O}_{3}$, compared to other DA techniques (e.g., Singh et al., 2011; Wu et al., 2008). This method seeks the optimal solution to minimize the cost functional in Eq. (1):

$$
\begin{aligned}
J\left(c_{0}, p\right)= & \frac{1}{2}\left(c_{0}-c_{0}^{b}\right)^{T} \mathbf{B}^{-1}\left(c_{0}-c_{0}^{b}\right)+\frac{1}{2}\left(p-p^{b}\right)^{T} \\
& \mathbf{P}^{-1}\left(p-p^{b}\right)+\frac{1}{2} \sum_{i=0}^{N}\left(h\left(c_{i}\right)-y_{i}\right)^{T} \mathbf{O}_{i}^{-1}
\end{aligned}
$$

where $\mathbf{B}, \mathbf{P}$, and $\mathbf{O}$ are error covariance matrices for the a priori model forecast (background), for any model parameters (such as emissions), and for available observations at any instant time $t=t_{i}$ within the assimilation window, respectively. The $h$ operator calculates the observation vector $y=y(x, t)$ from the model space $c=c(x, t)$.

The 4D-Var method minimizes Eq. (1) by applying minimization routines (in this study we use Quasi-Newton limited memory-Broyden-Fletcher-Goldfarb-Shanno (L-BFGS), a limited-memory quasi-Newton code for bound-constrained optimization as introduced by Zhu et al. (1997) and applied by Chai et al. (2006, 2007) in STEM 4D-Var) through iterations, and requires a model and its adjoint. The evolution of the adjoint variable vector $\lambda$ reads as

$$
\frac{\partial \lambda}{\partial t}+\nabla \cdot(\boldsymbol{u} \lambda)=-\nabla \cdot\left(\rho K \cdot \nabla \frac{\lambda}{\rho}\right)-(F \cdot \lambda)-\phi
$$

where $u$ is the wind field vector, $\rho$ the air density, $K$ the turbulent diffusivity tensor, and $\phi$ is a forcing functional vector which will be defined in Sect. 2.3. The backward integration of equation (2) gives adjoint variables at any time, and the variation of the cost functional due to small changes in initial conditions is

$\delta J=\left[\lambda_{0}^{T}+\left(c_{0}-c_{b}\right)^{T} \cdot B^{-1}\right] \cdot \delta c_{0}$

where $\lambda_{0}^{T}+\left(c_{0}-c_{b}\right)^{T} \cdot B^{-1}$ is the gradient information needed for the minimization. In contrast to the model forward sensitivity studies which quantify the response of chemical distributions in all grids at future times to the perturbation of model inputs/parameters, the distributions of the adjoint variable $\lambda_{n}$ in the entire computational domain, named as "instantaneous areas of influence" (Sandu et al., 2005), reflect backward in time the change of chemical distributions of the species $\mathrm{n}$ in grids that influence the response function (e.g., $\mathrm{O}_{3}$ concentrations at given receptor at a specific time). The adjoint values can: (1) help understand the specific processes that lead to a state of the atmosphere; (2) identify areas where perturbations/uncertainties in the concentration of the chemical species of interest at earlier times will result in significant changes in $\mathrm{O}_{3}$ levels at the receptor site at future time; and (3) help explain the 4D-Var DA efficiency. Adjoint sensitivity analysis and the 4D-Var DA have been applied in a number of previous studies from global to regional scales for gases and aerosols (e.g., Zhang et al., 2009; Kopacz et al., 2010; Zoogman et al., 2011; Henze et al., 2009; Carmichael et al., 2008; Chai et al., 2006, 2007, 2009; Hakami et al., 2005, 2006).

This study used STEM adjoint sensitivity simulations to understand the surface $\mathrm{O}_{3}$ sensitivities at two selected receptor regions (i.e., northern CA and OR (NWR) and southern CA (SCR)) with respect to concentrations of $\mathrm{O}_{3}$ backward in time during the study period (Cases FA1/FA2 and CA1/CA2 for the $12 \mathrm{~km}$ and $60 \mathrm{~km} / 18$ layer configurations, respectively, in Table 2). These cases help interpret the linkages between $\mathrm{O}_{3}$ at surface and at upwind measurement sites, as well as the effect of model resolution on the forward sensitivities in Sect. 3.2.2. The adjoint simulations require completion of forward model simulations, and they used the same model inputs as in the forward simulations. In each case, 27 adjoint sensitivity simulations (spanning the period of 16 June-14 July) were conducted, with 00:00 UTC of each day during 18 June-14 July as the final time, and an interval for each simulation of $49 \mathrm{~h}$.

Several types of observations (i.e., hourly surface $\mathrm{O}_{3}$, and the vertical profiles on 5 July from THD sonde, TES and OMI) were assimilated into the $12 \mathrm{~km}$ grid from $5 \mathrm{July}$, 18:00 UTC to 7 July, 00:00 UTC, a LRT episode detected by satellite and in-situ measurements (Ambrose et al., 2011). Ozone initial conditions were controlled in all DA cases (Table 3 ). The background error correlation matrix was prepared through the NMC (National Meteorological Center, now National Centers for Environmental Prediction) method using the 3-day, 2-day and same-day forecasts, and was inverted using the truncated singular value decomposition (TSVD) (Chai et al., 2007). The construction of background variances followed the method in Singh et al. (2011). Observation error 
Table 2. Description of STEM base and sensitivity (forward and adjoint) simulations ${ }^{\text {a }}$.

\begin{tabular}{|c|c|c|c|}
\hline & Cases & $\begin{array}{l}\text { Model grid } \\
\text { used }\end{array}$ & Description of model inputs and perturbations \\
\hline F0 & Base case & $12 \mathrm{~km} / 32 \mathrm{~L}^{\mathrm{c}}$ & $\begin{array}{l}\text { CARB anthropogenic and biogenic emissions, } \\
\text { MODIS/PREC-CHEM-SRC biomass burning } \\
\text { emissions, WRF meteorology, TBCs and LBCs } \\
\text { from the Case C0 results }\end{array}$ \\
\hline F1 & $50 \% \mathrm{BC} \mathrm{O}_{3}$ & $12 \mathrm{~km} / 32 \mathrm{~L}$ & TBCs and LBCs from the Case $\mathrm{C} 3$ results \\
\hline FA1/FA2 & $\begin{array}{l}\text { Adjoint NWR/SCR } \\
\text { cases }\end{array}$ & $12 \mathrm{~km} / 32 \mathrm{~L}$ & $\begin{array}{l}\text { Northern California and Oregon/ Southern Cal- } \\
\text { ifornia as receptors, control surface } \mathrm{O}_{3} \text { at } \\
\text { 00:00 UTC; simulation window for each day is } \\
49 \mathrm{~h} \text {. }\end{array}$ \\
\hline $\mathrm{C} 0$ & Base case & $60 \mathrm{~km} / 18 \mathrm{~L}$ & $\begin{array}{l}\text { NEI } 2001 \text { anthropogenic emissions, Orchidee } \\
\text { biogenic emissions, RAQMS biomass burn- } \\
\text { ing emissions, WRF meteorology, RAQMS and } \\
60 \mathrm{~km} \text { tracer results (Huang et al., 2012) as } \\
\text { gases and aerosol boundary conditions, respec- } \\
\text { tively. }\end{array}$ \\
\hline $\mathrm{C} 1$ & $50 \% \mathrm{TBC} \mathrm{O}_{3}$ & $60 \mathrm{~km} / 18 \mathrm{~L}$ & $\mathrm{TBC} \mathrm{O}_{3}$ reduced by $50 \%$ \\
\hline $\mathrm{C} 2 / \mathrm{C} 3 / \mathrm{C} 4$ & $25 \%, 50 \%$ and $75 \% \mathrm{BC} \mathrm{O}_{3}$ & $60 \mathrm{~km} / 18 \mathrm{~L}$ & $\begin{array}{l}\mathrm{TBC} \text { and } \mathrm{LBC}_{3} \text { reduced by } 75 \%, 50 \% \text { and } \\
25 \%\end{array}$ \\
\hline $\mathrm{C} 5 / \mathrm{C} 6 / \mathrm{C} 7$ & $\begin{array}{l}25 \%, 50 \% \text { and } 75 \% \\
\text { BCs for multiple species b }\end{array}$ & $60 \mathrm{~km} / 18 \mathrm{~L}$ & $\begin{array}{l}\text { TBCs and LBCs for multiple species reduced } \\
\text { by } 75 \%, 50 \% \text { and } 25 \%\end{array}$ \\
\hline $\mathrm{C} 8 / \mathrm{C} 9$ & $50 \%$ and $75 \%$ BC PAN & $60 \mathrm{~km} / 18 \mathrm{~L}$ & TBC and LBC PAN reduced by $50 \%$ and $25 \%$ \\
\hline $\mathrm{C} 10 / \mathrm{C} 11$ & $\begin{array}{l}\text { PAN composition/ } \\
\text { composition and } \\
\text { decomposition off }\end{array}$ & $60 \mathrm{~km} / 18 \mathrm{~L}$ & $\begin{array}{l}\text { Reaction(s) of PAN composition/composition } \\
\text { and decomposition are blocked }\end{array}$ \\
\hline $\mathrm{CA} 1 / \mathrm{CA} 2$ & Adjoint NWR/SCR cases & $60 \mathrm{~km} / 18 \mathrm{~L}$ & $\begin{array}{l}\text { Northern California and Oregon/ Southern Cal- } \\
\text { ifornia as receptors, control surface } \mathrm{O}_{3} \text { at } \\
\text { 00:00 UTC; simulation window for each day is } \\
49 \mathrm{~h} \text {. }\end{array}$ \\
\hline CLO & Base case & $60 \mathrm{~km} / 32 \mathrm{~L}$ & Same as $\mathrm{C} 0$, but using 32 vertical layers. \\
\hline CL1 & $50 \% \mathrm{BC} \mathrm{O}_{3}$ & $60 \mathrm{~km} / 32 \mathrm{~L}$ & Same as C3, but using 32 vertical layers. \\
\hline CR0 & scaled emissions & $60 \mathrm{~km} / 18 \mathrm{~L}$ & $\begin{array}{l}\text { Same as } \mathrm{C} 0 \text {, but scaled the US anthropogenic } \\
\mathrm{CO}, \mathrm{NO}_{\mathrm{x}} \text { and VOCs emissions based on EPA } \\
\text { emission trend. }\end{array}$ \\
\hline CR1 & $\begin{array}{l}50 \% \mathrm{BC} \mathrm{O}_{3} \text { and scaled } \\
\text { emissions }\end{array}$ & $60 \mathrm{~km} / 18 \mathrm{~L}$ & $\begin{array}{l}\text { Same as } \mathrm{C} 3 \text {, but scaled the US anthropogenic } \\
\mathrm{CO}, \mathrm{NO}_{\mathrm{x}} \text { and VOCs emissions based on EPA } \\
\text { emission trend. }\end{array}$ \\
\hline CBB & $\begin{array}{l}\text { biomass burning emissions } \\
\text { off }\end{array}$ & $60 \mathrm{~km} / 18 \mathrm{~L}$ & $\begin{array}{l}\text { Same as } \mathrm{C} 0 \text {, but not including the biomass burn- } \\
\text { ing emissions }\end{array}$ \\
\hline CBG & biogenic emissions off & $60 \mathrm{~km} / 18 \mathrm{~L}$ & $\begin{array}{l}\text { Same as } \mathrm{C} 0 \text {, but not including the biogenic } \\
\text { emissions }\end{array}$ \\
\hline
\end{tabular}

a The studied period for each simulation case in this table was 16 June-14 July, 2008.

b Multiple species in cases C5-C7 refer to the shared non- $\mathrm{O}_{3}$ gaseous species in TBCs/LBCs, including: $\mathrm{CO}, \mathrm{NO}, \mathrm{NO}_{2}, \mathrm{NO}_{3}, \mathrm{HNO}_{3}, \mathrm{HNO}_{4}, \mathrm{PAN}$ and

$\mathrm{N}_{2} \mathrm{O}_{5}$.

c L: Layers

Abbreviations

CARB: California Air Resources Board; NEI: National Emission Inventory; PAN: Peroxyacetyl nitrate; RAQMS: Real-time Air Quality Modeling System; TBCs/LBCs: Top/Lateral Boundary Conditions; WRF: Weather Research and Forecasting Model

covariance matrices are diagonal, and the selection of observation errors for each case (Table 3 ) accounted the instrument uncertainties and the representative errors (due to the gap of spatial resolution between measurements and model). Upperlimits of each chemical species (useful for the optimization routine, as described in Chai et al., 2006) varied vertically, 
and for $\mathrm{O}_{3}$ they were set at $200 \mathrm{ppb}$ from surface to midtroposphere, and $400 \mathrm{ppb}$ in the upper troposphere reflected by satellite retrievals on 5 July (Sect. 3.4). All cases used 25 iterations, and the cost function decreased significantly after $\sim 12-15$ iterations (e.g., $>\sim 40 \%$, Fig. S6).

\subsection{Observation operator and the forcing term}

The observation operator $\mathrm{h}(\mathrm{c})$, which can vary for different types of observations, enables the comparison of modeled $\mathrm{O}_{3}$ fields with the observations. It is critical for (1) evaluating model performance; and (2) calculating cost function and the forcing term for DA. For surface measurements and sondes, $\mathrm{h}(\mathrm{c})$ is linearly-interpolated model output to observations locations.

The TES retrieval follows (4) (Chapter 8, TESL2 data user's guide, Version 5.0, 2011):

$\bar{z}=z_{\mathrm{c}}+\mathbf{A}_{\mathrm{TES}}\left(z-z_{\mathrm{c}}\right)+\varepsilon$

where $\hat{z}, \mathrm{z}$ and $\mathrm{z}_{c}$ are the natural $\log$ form of the estimated state, true state, and constraint vectors for $\mathrm{O}_{3}$ concentrations (in volume mixing ratio (vmr) units), respectively. $\varepsilon$ is the TES observation error that assumed to have mean zero and covariance $S$ (Bowman et al., 2006), and $\mathrm{A}_{\mathrm{TES}}$ is the averaging kernel matrix (usually non-symmetric) reflecting the sensitivity of retrieval to changes in the true state (Rogers, 2000). Retrieval in vmr is $y=\exp (\hat{z})$. The TES observation operator $\mathrm{h}_{z}$ for $\mathrm{O}_{3}$ is written in (5):

$h_{z}=z_{c}+\mathrm{A}_{\mathrm{TES}}\left(\ln \left(F_{\mathrm{TES}}(c)\right)-z_{c}\right)$

where $\mathrm{F}_{\text {TES }}$ projects the modeled $\mathrm{O}_{3}$ fields $\mathrm{c}$ to the TES grid using spatial and temporal interpolation. The resulting mismatches in vmr between TES retrieval and the model state are the differences of the exponential form of (4) and (5) (i.e., $\left.\exp (\bar{z})-\exp \left(h_{z}\right)\right)$ at each location along the orbit, which is used to calculate the cost functional in Eq. (1). Usually $\varepsilon$ is much lower than the mismatches between model and satellite retrieval.

The OMI observation operator is built upon the similar function of constraint vectors and averaging kernels as for TES, except that the $\mathrm{O}_{3}$ concentrations in retrievals are in Dobson Units (DU) per layer, and should be converted to layer average by using (6):

$\langle\mathrm{vmr}\rangle_{i}\left(\right.$ in ppb) $=1.2672 \times 10^{3} \times N_{i} / \mathrm{d} P_{i}$

where $N_{i}$ is partial column in DU in the layer, and $\mathrm{d} P_{i}$ is the pressure difference between the bottom and the top of the layer in hPa. Accordingly, the OMI averaging kernel for the profiles in DU should be converted for the profiles in vmr using Eq. (7) (Veefkind et al., 2009):

$A_{\mathrm{OMIij}}^{\mathrm{vmr}}=\mathrm{A}_{\mathrm{OMIij}}^{\mathrm{DU}} \times \mathrm{d} P_{j} / \mathrm{d} P_{i}$

The forcing term $\phi$ in Eq. (2) appears as in Eq. (8)

$\phi=H^{T} O^{-1}(h(c)-y)$, where $H=\partial h(c) / \partial c$ and $y$ is the observation.

For assimilating surface observations, $h(c)=H \cdot c$, where $\mathrm{H}$ reflects interpolation in space and time when constructing model counterparts of the observations). For assimilating TES and OMI profiles, $\mathrm{H}^{T}$ follows Eqs. (9) and (9), respectively.

$$
\begin{aligned}
H^{T}=\left(\frac{\partial\left[\exp \left(h_{z}\right)\right]}{\partial c}\right)^{T} & =\left(\frac{\partial\left[\exp \left(z_{c}+\mathrm{A}_{\mathrm{TES}}\left(\ln \left(\mathrm{F}_{\mathrm{TES}}(c)\right)-z_{\mathrm{c}}\right)\right)\right]}{\partial c}\right)^{T} \\
& =\mathrm{F}_{\mathrm{TES}}^{T} \frac{1}{\mathrm{~F}_{\mathrm{TES}}} \cdot \mathrm{A}_{\mathrm{TES}}^{T} \cdot \exp \left(h_{z}\right)^{T}
\end{aligned}
$$

$H^{T}=\mathrm{F}_{\mathrm{OMI}}^{T} \cdot \mathrm{A}_{\mathrm{OMI}}^{\mathrm{vmr} T}$

\section{Results and discussions}

\subsection{Forward sensitivity of surface $\mathrm{O}_{3}$ to $\mathrm{BCs}$}

\subsubsection{Model evaluation for base case surface $\mathrm{O}_{3}$}

Figure 2 compares two $\mathrm{O}_{3}$ regulatory metrics at surface sites (225 AQS sites and 8 CASTNET sites that had data available for $>=75 \%$ of the daytimes during the studied period and were located inside of both $60 \mathrm{~km}$ and $12 \mathrm{~km}$ model domains) with the model results generated in $60 \mathrm{~km}$ and $12 \mathrm{~km}$ grids. The two metrics are Monthly mean Daily maximum 8-h Average $\mathrm{O}_{3}$ (MDA8) and W126 Monthly Index (MI, calculation followed the method: http://www.epa.gov/ $\mathrm{ttn} /$ analysis/w126.htm) for primary and secondary $\mathrm{O}_{3}$ standards, which set limits to protect human health and public welfare, respectively. Both observed and modeled $\mathrm{O}_{3}$ show highest concentrations over the Central Valley and southern CA (with MDA8 $>75$ ppb and W126 > 15 ppm-h). Ozone levels over most areas of NV, OR and WA are lower (with MDA $8<60 \mathrm{ppb}$ and W126 $<7 \mathrm{ppm}-\mathrm{h}$ ). The $60 \mathrm{~km}$ and $12 \mathrm{~km}$ simulations present similar gradients, and the $12 \mathrm{~km}$ results capture more accurately the local features. The predictions show higher positive biases along the coast, larger in the $60 \mathrm{~km}$ grid, which may be caused by uncertainties in emissions (especially the biomass burning emissions) and the $\mathrm{BCs}$, as well as the inaccuracies in predicted meteorology associated with complicated land-sea breezes and topography.

Statistical comparisons between the observed and modeled MDA8 and W126 were calculated at these AQS (Table 4a) and CASTNET sites (Table 4b), including root mean square error (RMSE), mean bias (bias = modeled-observed), mean error (error $=\mid$ modeled-observed $\mid$ ), mean fractional bias (fractional bias $=2 \times($ modeled-observed $) /($ modeled + observed $))$ and mean fractional error (fractional error $=2 \times \mid$ (modeledobserved)/(modeled + observed)|) (suggested by Boylan and Russell, 2006). The model performance is generally good for MDA8, similar to the contemporary community chemical 

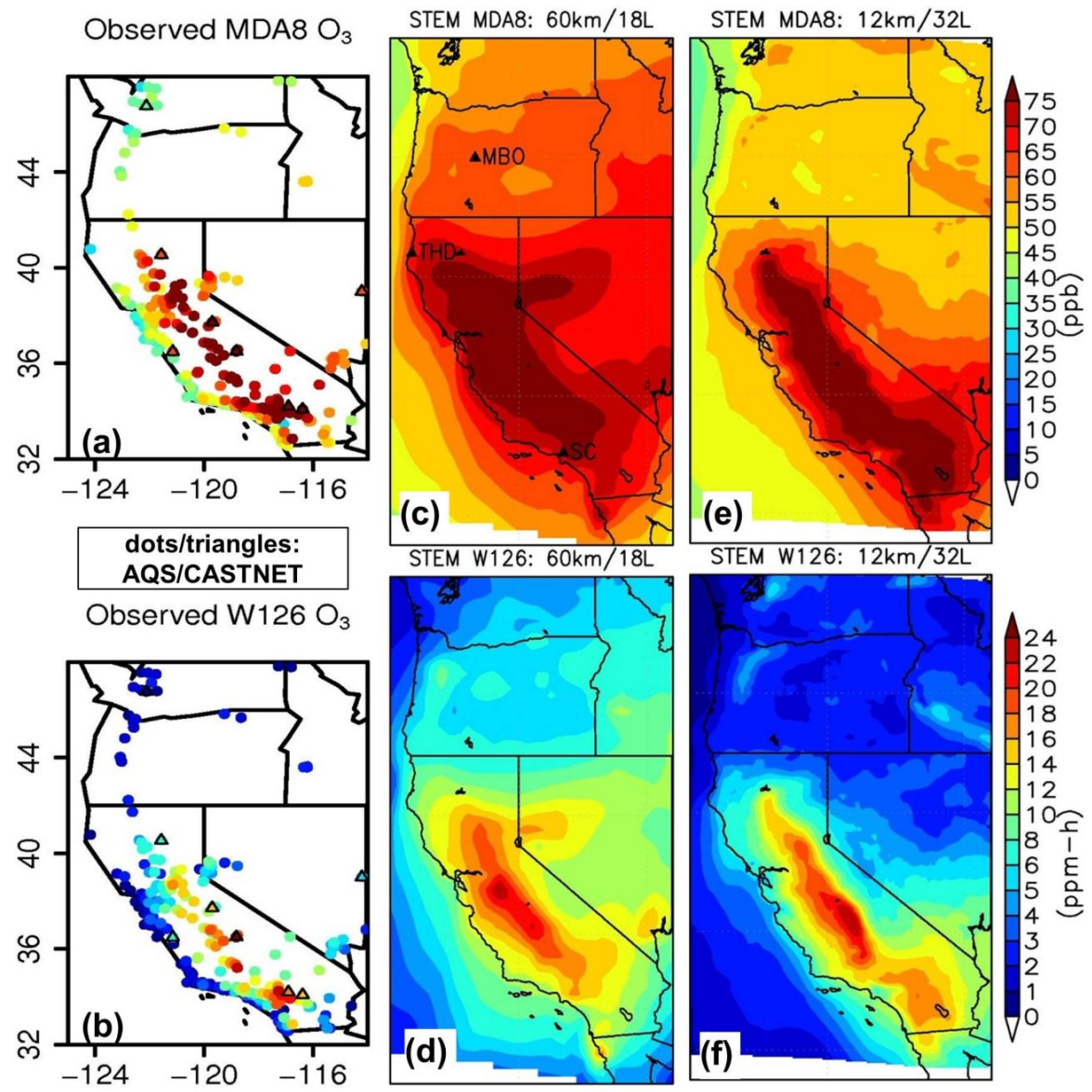

Fig. 2. Comparison of observed and modeled MDA8 and W126 monthly index (MI). See text in Sect. 3.1.1 for definition of MDA8 and W126 MI indexes. (a-b) Observed MDA8 and W126 MI at EPA AQS (dots) and CASTNET (triangles) sites; Modeled surface (c,e) MDA8 and (d,f) W126 MI in (c-d) $60 \mathrm{~km} / 18$ layer and (e-f) $12 \mathrm{~km} / 32$ layer grids.

weather forecast model evaluations (e.g., McKeen et al., 2009), and the model performs better at CASTNET sites than at AQS sites, due to the fewer number of CASTNET sites and weaker anthropogenic influences on $\mathrm{O}_{3}$ over these rural/remote locations. The $12 \mathrm{~km}$ results show better performance with lower bias, error and RMSE.

\subsubsection{Impacts of multiple TBG species on surface $\mathrm{O}_{3}$}

The sensitivities of surface MDA8 and W126 metrics to various species in BCs were evaluated by a number of forward sensitivity simulations (Sect. 2.3.2), and the results were averaged over ten EPA regions (Fig. 3a-b). The largest sensitivities are found in the west (Regions 8, 9, and 10), which is less populated (text below Fig. 3c) and has larger grass/shrub coverage (barplot in Fig. 3c, grouped from the US Geological Survey (USGS) 24 land types used in the model simulations, Table S2). The eastern US has a higher population density and larger forest coverage, and shows $\sim 1 / 3$ of the sensitivity to TBG pollutants as that for the west. For all EPA regions, surface MDA8 and $\mathrm{W} 126$ are most sensitive to $\mathrm{TBG} \mathrm{O}_{3}$, followed by PAN.

Sonde-based studies have shown that the impacts of stratospheric $\mathrm{O}_{3}$ may be the main reason for modifying the $\mathrm{O}_{3}$ vertical structures in summer (Cooper et al., 2007). The stratospheric $\mathrm{O}_{3}$ impacts on tropospheric $\mathrm{O}_{3}$ distributions in regional chemical transport models can be affected by $\mathrm{O}_{3}$ variability in model TBCs, the location(s) of the model top boundary, and the model vertical resolutions. The periodmean $\mathrm{O}_{3}$ TBC taken from RAQMS ranged from 80-220 ppb, decreasing from June to July. The sensitivities of MDA8 and W126 to $50 \%$ perturbation in the $\mathrm{O}_{3}$ TBCs in the western US are below $1 \mathrm{ppb}$ and $1 \mathrm{ppm}-\mathrm{h}$, respectively (Fig. 3a-b), with higher values over the high topography regions of eastern ID, Wyoming (WY) and Colorado. This method ignores the impacts of stratospheric-origin $\mathrm{O}_{3}$ included in $\mathrm{LBC} \mathrm{O}_{3}$.

We further analyzed the sensitivity of MDA8 and W126 in Regions 9 and 10 over different geographical regions/land types to the magnitude of $\mathrm{BC}$ perturbations for multiple species (Fig. 3e-f). The TBG impact is largest on grass/shrub 
(a)MDA8: mean sensitivities to BCs by regions
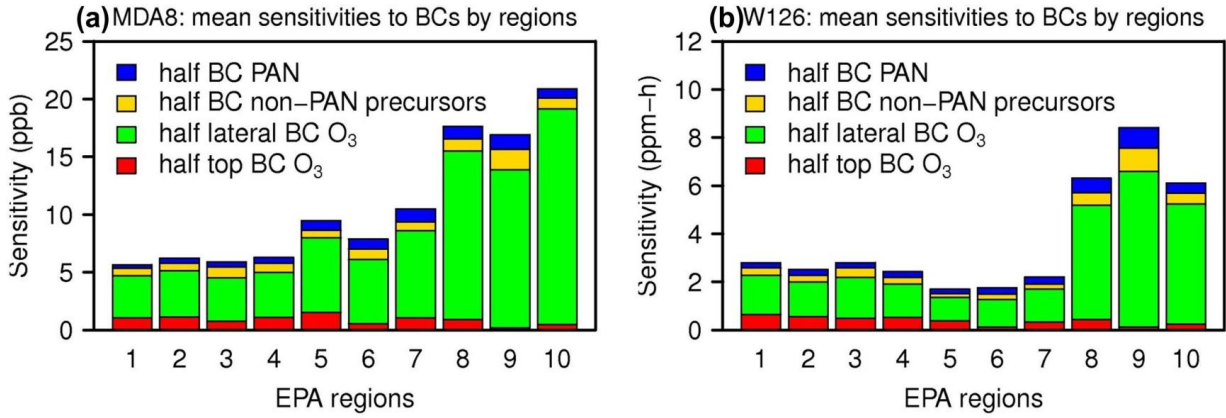

Grouped land types (USGS)

(c) forest grass/shrub crop

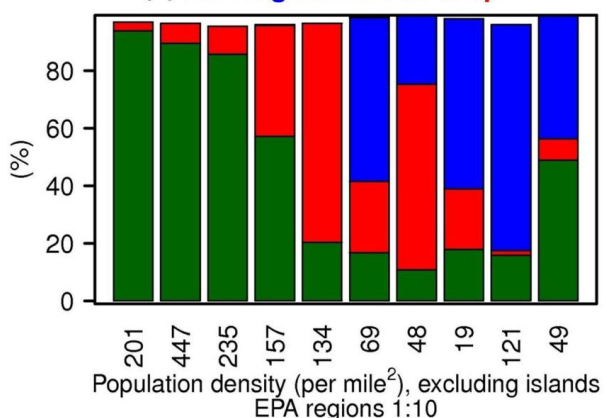

(d) EPA regions

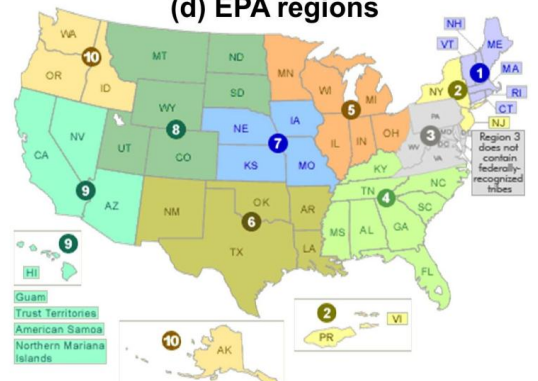

http://www.epa.gov/tp/whereyoulive/regions.htm
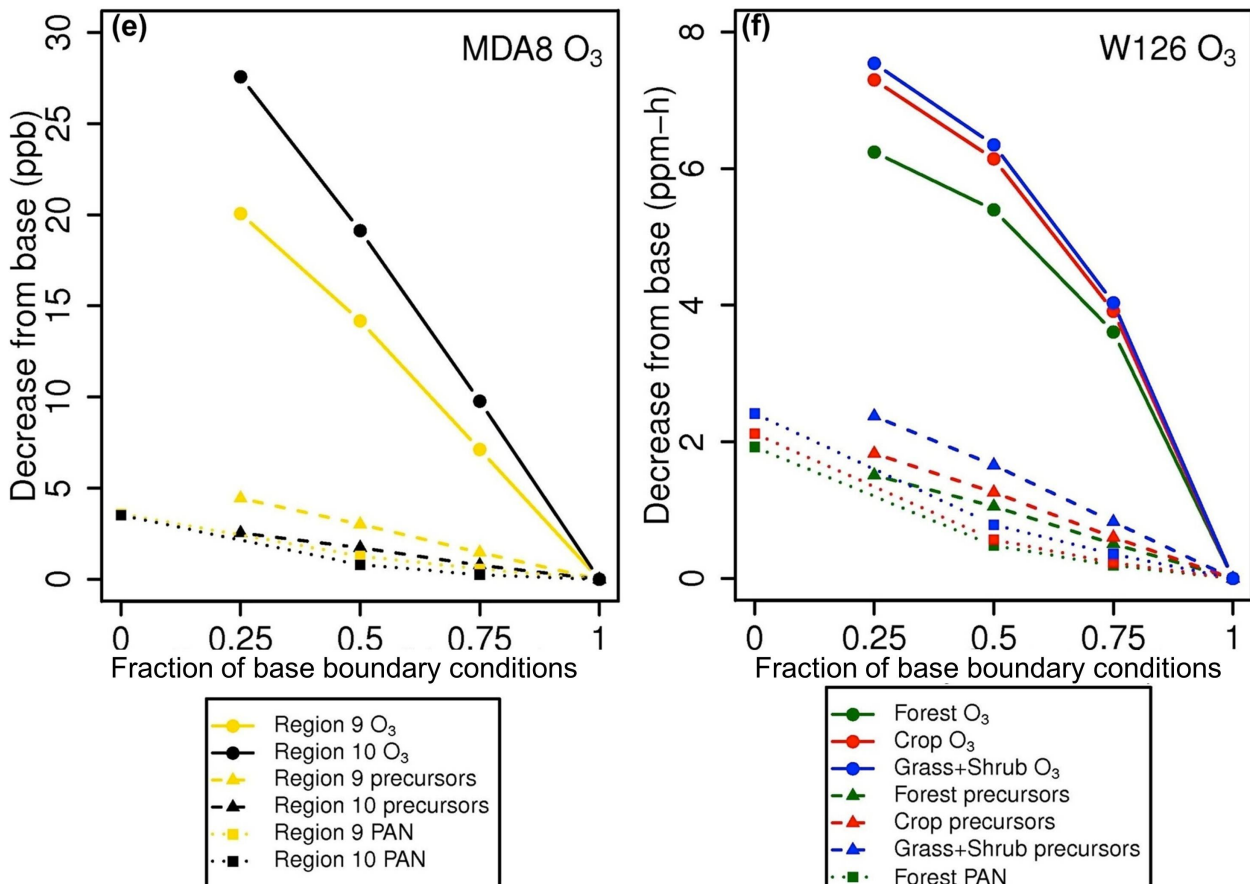

\begin{tabular}{|ll|}
\hline- & Forest $\mathrm{O}_{3}$ \\
- & ${\text { Crop } \mathrm{O}_{3}}$ \\
- & Grass + Shrub $\mathrm{O}_{3}$ \\
- & Forest precursors \\
- & Crop precursors \\
- & Grass+Shrub precursors \\
$\cdots \cdot$ & Forest PAN \\
$\cdots \cdot$ & Crop PAN \\
$\cdots \cdot$ & Grass+Shrub PAN
\end{tabular}

Fig. 3. Surface (a) MDA8 and (b) W126 responses to perturbations in boundary conditions in the $60 \mathrm{~km} / 18$ layer grid, shown by ten EPA regions. (c) Fractions of the grouped USGS land types (bar) and population densities (text below the bar) in ten EPA regions. (d) The ten EPA regions; Surface (e) MDA8 and (f) W126 responses to perturbations of various species in boundary conditions in the $60 \mathrm{~km} / 18$ layer grid, shown by geographical regions (EPA Regions 9 and 10) and grouped USGS land types, respectively ("precursors" in legends: the cases in which $\mathrm{CO}, \mathrm{NO}, \mathrm{NO}_{2}, \mathrm{NO}_{3}, \mathrm{HNO}_{3}, \mathrm{HNO}_{4}, \mathrm{PAN}, \mathrm{N}_{2} \mathrm{O}_{5}$ in $\mathrm{BCs}$ were perturbed). 
Table 3. Description of 4-D Var data assimilation cases in the $12 \mathrm{~km}$ model grid *

\begin{tabular}{|c|c|c|c|}
\hline & Cases & Descriptions & Observation error (s) \\
\hline AS & $\begin{array}{l}\text { Assimilate observations from } \\
\text { AQS, CASTNET and MBO } \\
\text { sites }\end{array}$ & $\begin{array}{l}\text { Assimilate available observa- } \\
\text { tions at all times in the assim- } \\
\text { ilation window. CASTNET and } \\
\text { MBO observations were assim- } \\
\text { ilated at actual altitudes. AQS } \\
\text { observations were assimilated } \\
\text { from the surface level. }\end{array}$ & $\begin{array}{l}\text { constant } 3 \text { ppb: maximum rep- } \\
\text { resentative error (defined by } \\
\text { Chai et al., 2007) in each grid } \\
\& \sim 10 \% \text { of mean observations } \\
\text { in the assimilation window }\end{array}$ \\
\hline AT & $\begin{array}{l}\text { Assimilate } \mathrm{O}_{3} \text { vertical profiles } \\
\text { from TES special observations }\end{array}$ & $\begin{array}{l}\text { TES special observations were } \\
\text { assimilated at Aura overpass } \\
\text { time ( } \sim 22: 00 \text { UTC, } 5 \text { July). } \\
\text { Only the observations with } \\
\text { quality flag }=1 \text { and cloud opti- } \\
\text { cal depth }<=2.0 \text { were used. }\end{array}$ & $\begin{array}{l}\text { constant } 6 \mathrm{ppb} \text { for TES }(\sim 7 \% \\
\text { of mean } 84 \mathrm{ppb}) \text { : Nassar et al., } \\
2008 \text {, and Boxe et al., } 2010\end{array}$ \\
\hline $\mathrm{AO}$ & $\begin{array}{l}\text { Assimilate } \quad \mathrm{OMI} \mathrm{O}_{3} \text { vertical } \\
\text { profiles }\end{array}$ & $\begin{array}{l}\text { OMI observations were assim- } \\
\text { ilated at Aura overpass time } \\
(\sim 22: 00 \text { UTC, } 5 \text { July). Only the } \\
\text { observations at places where } \\
\text { MODIS cloud fraction }=0 \text { were } \\
\text { used (suggested by Russell et } \\
\text { al., 2011). }\end{array}$ & $\begin{array}{l}\text { constant } 11 \mathrm{ppb} \text { for OMI: } 10 \% \\
\text { of mean } \sim 110 \mathrm{ppb}\end{array}$ \\
\hline $\mathrm{AD}$ & Assimilate $\mathrm{THD} \mathrm{O}_{3}$ sonde & $\begin{array}{l}\mathrm{O}_{3} \text { sondes at } \mathrm{THD} \text { were } \\
\text { binned into model levels and } \\
\text { assimilated at the launch time } \\
(\sim 19: 00 \text { UTC, } 5 \text { July }) .\end{array}$ & $\begin{array}{l}\text { constant 5 ppb: } \sim 10 \% \\
\text { (Thompson et al., } 2010 \text {; } \\
\text { Liu et al., 2009) of mean } \\
\text { observations at all levels in the } \\
\text { troposphere }\end{array}$ \\
\hline AST & Assimilate site \& $\mathrm{TES} \mathrm{O}_{3}$ & \multicolumn{2}{|c|}{ Combination of cases AS and AT } \\
\hline ASO & Assimilate site \& $\mathrm{OMI} \mathrm{O}_{3}$ & \multicolumn{2}{|c|}{ Combination of cases AS and AO } \\
\hline ASD & 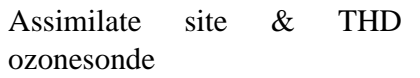 & \multicolumn{2}{|c|}{ Combination of cases AS and AD } \\
\hline
\end{tabular}

* All cases used the same background error correlation matrix calculated by the NMC method as introduced by Chai et al. (2007). Assimilation window was 18:00 UTC, 5 July-00:00 UTC, 7 July 2008 (30 h).

and smallest on forest for all sensitivity cases. Both MDA8 and W126 show close-to-linear response to perturbations in several non- $\mathrm{O}_{3}$ species in $\mathrm{BCs}$, but non-linear responses to perturbations in $\mathrm{BC}_{3}$ and PAN. MDA8 sensitivity over Region 9 shows stronger non-linearity to BC PAN perturbations than over Region 10, reflecting stronger local impacts.

\subsubsection{TBG contributions with bias corrections}

We estimated the absolute TBG contributions to surface MDA8 and W126 by summing up the contributions from TBG $\mathrm{O}_{3}$ and its precursors, extrapolated from their sensitivity curves to the $\mathrm{BC}$ perturbations. The extrapolation method is described in detail (and for W126 we compared the impact of using four different extrapolation methods on the results) in Section S2 and Figs. S1 and S2. The maximum TBG contributions over the western US occur over northwestern US (e.g., ID and OR) and the Central Valley, respec- tively (Fig. 4a,d). After exploring the relationships between the model biases in the base simulation and the estimated TBG contributions at surface sites (details in Sect. S3), we concluded that the bias-corrected estimates of TBG contributions to MDA8 are $\sim 30-35 \mathrm{ppb}$ for Regions 9 and 10. The contributions to W126 are $\sim 10-17$ ppm-h for Region 9 and 3-4 ppm-h for Region 10.

Pfister et al. (2011b) concluded that $53 \pm 21 \%$ of $\mathrm{CO}$ over CA came from model boundary during ARCTAS, close to our estimates of TBG contributions to surface MDA8. They also found that $\sim 1 / 4$ of these (14 $\pm 6 \%$ of the total) had an Asian origin. Based on this relationship and our estimates of TBG contributions, the upper limits of Asian contribution to MDA8 and W126 are $\sim 9 \mathrm{ppb}$ and $\sim 1-4 \mathrm{ppm}-\mathrm{h}$, respectively. Since $\mathrm{O}_{3}$ and $\mathrm{CO}$ have different lifetimes and sources, a more quantitative estimation of the Asian emissions contribution to 

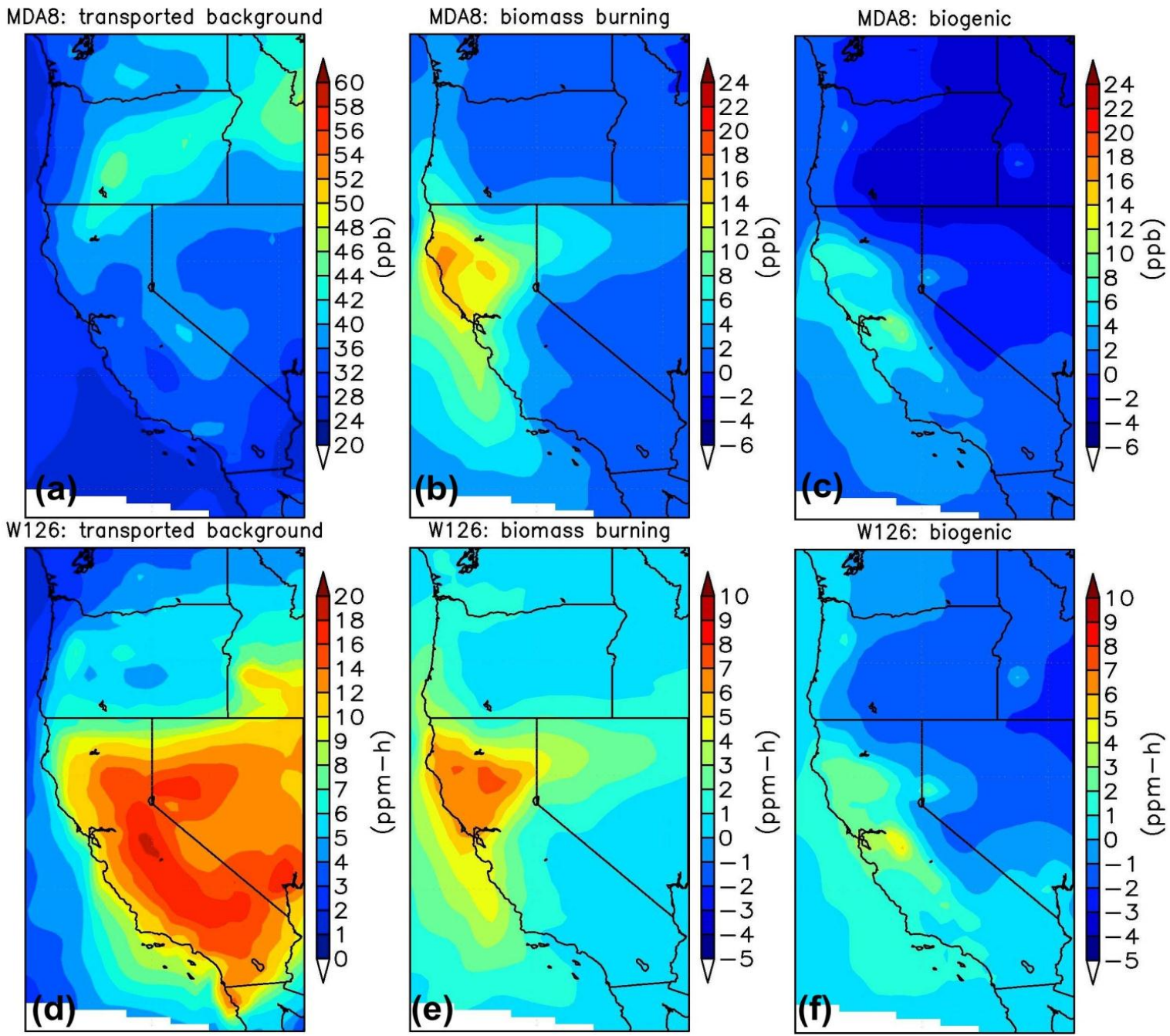

Fig. 4. Surface (a-c) MDA8 and (d-f) W126 contributed from (a,d) transported background based on extrapolation; (b,e) North American biomass burning and (c,f) biogenic emissions. The extrapolation methods to calculate (a) and (d) are described in Sect. S1.

$\mathrm{O}_{3}$ will require sensitivity simulations or tagging methods in global models.

\subsubsection{Comparison with biomass burning and biogenic emissions contributions to background $\mathrm{O}_{3}$}

Two other background $\mathrm{O}_{3}$ contributors, biomass burning and biogenic emissions, are compared with the TBG contributions and show more spatially-limited and weaker impacts (Fig. 4). Biomass burning contributes up to $18 \mathrm{ppb}$ and 9 ppm-h to MDA8 and W126, respectively, with the strongest impacts over northern CA. Biogenic emissions have slight negative impacts over most regions in NV, ID, WA and OR, due to the $\mathrm{NO}_{\mathrm{x}}$ sensitive regime. The strongest sensitivities occur over northern CA and the Central Valley, up to $\sim 15 \mathrm{ppb}$ and 6-8 ppm-h for MDA8 and W126, respectively.

\subsection{Other factors affecting surface $\mathrm{O}_{3}$ sensitivities to $\mathrm{BCs}$}

Because of the non-linearity of $\mathrm{O}_{3}$ chemistry and the complex topography over the western US, in addition to the quality of BCs, other factors such as NA anthropogenic emissions and the model resolutions can also affect the model estimated TBG contributions. In this section, we discuss in detail their effects on surface $\mathrm{O}_{3}$ sensitivities to $50 \%$ perturbations in $B C \mathrm{O}_{3}$, since TBG $\mathrm{O}_{3}$ is the major contributor among the TBG pollutants.

The spatial distributions of the sensitivities of MDA8 and W126 to $50 \%$ reduction in $\mathrm{BC} \mathrm{O}_{3}$ are shown in Fig. 5 for several western states. OR and WA show the lowest absolute sensitivity SEN1 (SEN1 = base case-sensitivity case) for W126 but the highest for MDA8, while broad regions in CA and NV show the highest SEN1 to W126 but lowest for 

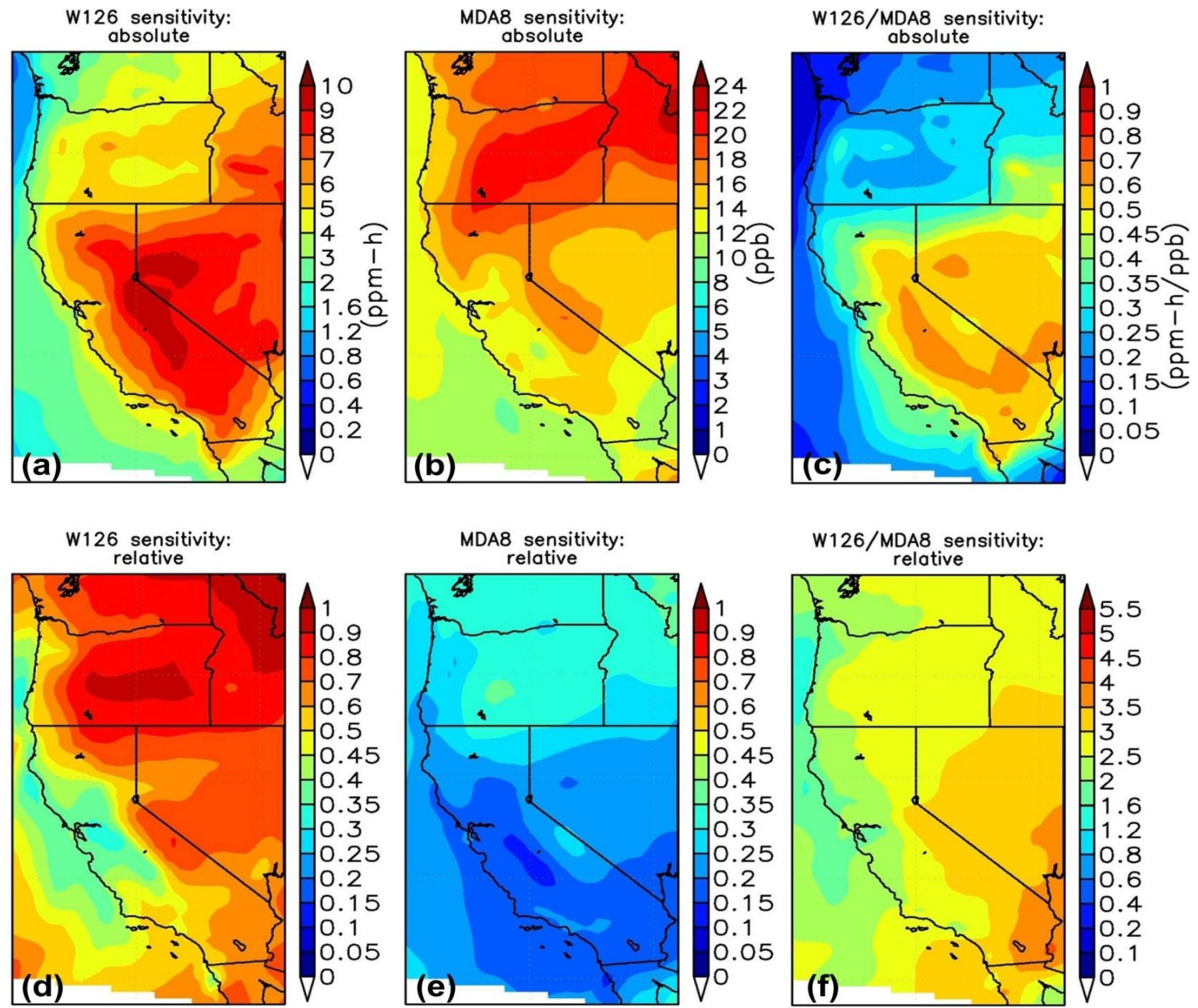

W126/MDA8 sensitivity:

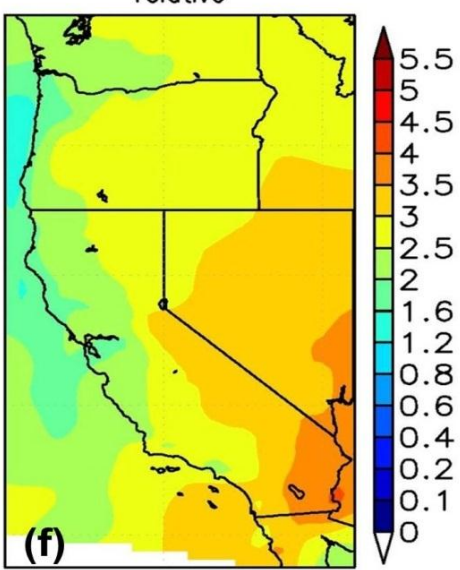

Fig. 5. The $\mathrm{O}_{3}$ sensitivity to $50 \%$ reduction in $\mathrm{O}_{3}$ boundary conditions. The surface $\mathrm{O}_{3}$ sensitivity SEN1 (SEN1 = base case-sensitivity case) of (a) W126; (b) MDA8 and (c) ratio of (a)/(b). The surface $\mathrm{O}_{3}$ relative sensitivity SEN2 (SEN2 = (base case-sensitivity case)/base case) of (d) W126; (e) MDA8 and (f) ratio of (d)/(e). Results are from the $60 \mathrm{~km} / 18$ layer grid. The mean sensitivities in (a) and (b) are $5.4 \mathrm{ppm}-\mathrm{h}$ and $15.5 \mathrm{ppb}$, respectively, over the plotted domain.

Table 4a. Statistics for observed and modeled surface $\mathrm{O}_{3}$ metrics at EPA AQS sites as shown in Fig. 2 (better performance in bold). Model results were extracted at surface using the linear interpolation method ${ }^{\mathrm{a}, \mathrm{b}}$.

\begin{tabular}{lrrrrrr}
\hline Statistics & \multicolumn{3}{c}{ MDA8 } & \multicolumn{3}{c}{ W126 MI } \\
\cline { 2 - 7 } & Observation & $60 \mathrm{~km} / 18 \mathrm{~L}$ & $12 \mathrm{~km} / 32 \mathrm{~L}$ & Observation & $60 \mathrm{~km} / 18 \mathrm{~L}$ & $12 \mathrm{~km} / 32 \mathrm{~L}$ \\
\hline Mean & 57.63 & 74.08 & 69.17 & 6.63 & 13.79 & 11.04 \\
Standard Deviation & 16.75 & 7.78 & $\mathbf{1 0 . 3 2}$ & 5.98 & 4.17 & $\mathbf{4 . 9 1}$ \\
Mean Bias & - & 16.45 & $\mathbf{1 1 . 5 4}$ & - & 7.16 & $\mathbf{4 . 4 1}$ \\
Mean Error & - & 18.52 & $\mathbf{1 3 . 3 3}$ & - & 7.82 & $\mathbf{5 . 1 5}$ \\
Root Mean Square Error & - & 21.55 & $\mathbf{1 5 . 6 3}$ & - & 8.74 & $\mathbf{5 . 9 7}$ \\
Mean Fractional Bias & - & 0.28 & $\mathbf{0 . 2 1}$ & - & 0.92 & $\mathbf{0 . 7 4}$ \\
Mean Fractional Error & - & 0.31 & $\mathbf{0 . 2 3}$ & - & 0.96 & $\mathbf{0 . 7 9}$ \\
\hline
\end{tabular}

${ }^{\mathrm{a}}$ Units (except Mean Fractional Bias/Error are dimensionless) for MDA8 are ppb; for W126 are ppm-h.

${ }^{b}$ L: Layers 

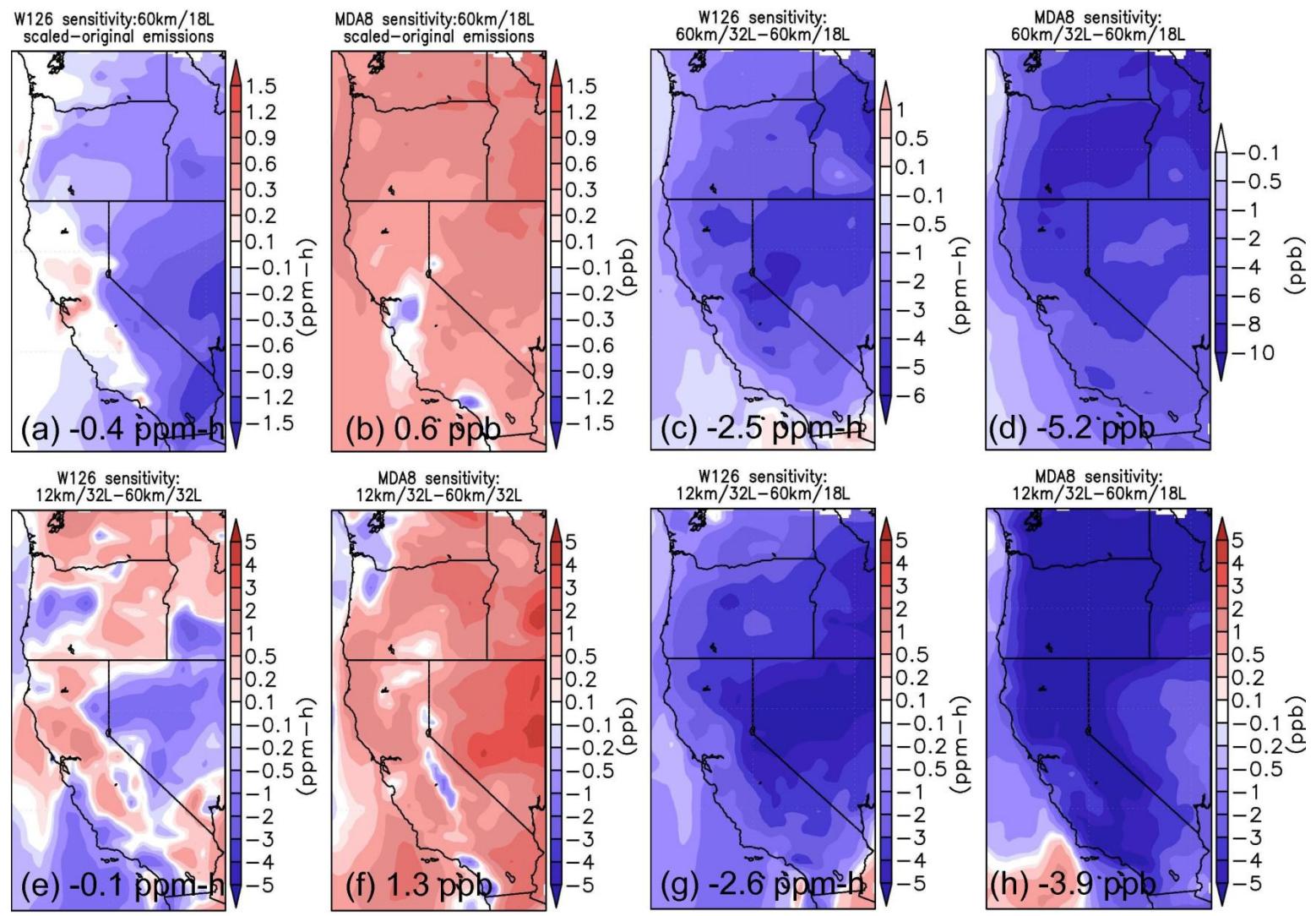

Fig. 6. Differences of SEN1 (defined in Fig. 5 caption) for (a,c,e,g) W126 and (b,d,f,h) MDA8 between the cases of (a-b) using the scaled and original US anthropogenic emissions in the $60 \mathrm{~km} / 18$ layer grid; (c-d) in $60 \mathrm{~km} / 32$ layer and $60 \mathrm{~km} / 18$ layer grids; (e-f) in $12 \mathrm{~km} / 32$ layer and $60 \mathrm{~km} / 32$ layer grids; and $(\mathbf{g}-\mathbf{h})$ in $12 \mathrm{~km} / 32$ layer and $60 \mathrm{~km} / 18$ layer grids. Numbers besides the labels are mean differences in the sensitivities over the plotted domain.

MDA8. ID shows strong SEN1 for both MDA8 and W126 due to its high topography. The relative sensitivities SEN2 $(\mathrm{SEN} 2=($ base case-sensitivity case $) /$ base case, dimensionless) of MDA8 and W126 both show maxima over the northwestern US (ID, WA and OR), where $\mathrm{O}_{3}$ in the base case is much lower than over CA. The different features in W126 are due to the non-linear function used in the calculation that gives greater weights for high hourly $\mathrm{O}_{3}$ concentrations. The ratio of W126/MDA8 sensitivities indicates regions where W126 levels are more sensitive to extra-regional sources than MDA8. Regions of high SEN1 ratios (>0.6) appear over the Central Valley and southern CA where regional photochemical production is strong. The SEN2 ratios are overall higher than those of SEN1, with the higher values in NV, ID and $\mathrm{OR}(>3)$.

\subsubsection{Impacts of NA anthropogenic emissions}

To evaluate the extent to which SEN1 of MDA8 and W126 are dependent on the magnitude of NA anthropogenic emissions, we conducted base and $50 \% \mathrm{BC} \mathrm{O}_{3}$ forward sensitivity simulations in the $60 \mathrm{~km} / 18$ layer grid, with US anthropogenic emissions for $\mathrm{NO}_{\mathrm{x}}, \mathrm{CO}$, and VOCs scaled by $\sim 0.7, \sim 0.7$ and $\sim 0.9$, respectively (based on the US emission trend from $\sim 2000$ to 2008 (http://www.epa.gov/ ttnchie1/trends/, using data except wildfires, accessed in December, 2011). The changes in SEN1 of MDA8 and W126 in the scaled emission conditions are generally within $\pm 1.5 \mathrm{ppb}$ and $\pm 1.5 \mathrm{ppm}-\mathrm{h}$, respectively (Fig. $6 \mathrm{a}-\mathrm{b}$ ). The urban regions in CA show lower SEN1 for MDA8 but higher SEN1 for W126, while the remaining areas show the opposite sign for the changes (due to different $\mathrm{O}_{3}$ production regimes).

\subsubsection{Impacts of model horizontal and vertical resolution}

To assess the impacts of vertical resolution on SEN1 of MDA8 and W126, we conducted base and half $\mathrm{BC} \mathrm{O}_{3}$ simulations in a $60 \mathrm{~km} / 32$ layer grid to compare with SEN1 in the $60 \mathrm{~km} / 18$ layer grid. Adding vertical resolution reduces SEN1 of MDA 8 and W126 by up to $\sim 10 \mathrm{ppb}(10-40 \%)$ and $6 \mathrm{ppm}-\mathrm{h}(30-50 \%)$, respectively, and the largest reduction in SEN1 for MDA8 and W126 occur over the OR/ID mountain areas and ID/NV grass/shrub and forest areas, respectively 
Table 4b. Same as Table 4a but for CASTNET sites, and model results were extracted at identical site altitudes ${ }^{\mathrm{a}, \mathrm{b}}$.

\begin{tabular}{lrrrrrr}
\hline Statistics & \multicolumn{3}{c}{ MDA8 } & \multicolumn{3}{c}{ W126 MI } \\
\cline { 2 - 7 } & Observation & $60 \mathrm{~km} / 18 \mathrm{~L}$ & $12 \mathrm{~km} / 32 \mathrm{~L}$ & Observation & $60 \mathrm{~km} / 18 \mathrm{~L}$ & $12 \mathrm{~km} / 32 \mathrm{~L}$ \\
\hline Mean & 71.61 & 72.07 & 70.67 & 11.77 & 12.66 & 10.79 \\
Standard Deviation & 19.51 & 7.94 & $\mathbf{1 1 . 7 8}$ & 7.99 & 4.02 & $\mathbf{5 . 7 0}$ \\
Mean Bias & - & $\mathbf{0 . 4 6}$ & -0.94 & - & $\mathbf{0 . 8 9}$ & -0.98 \\
Mean Error & - & 12.52 & $\mathbf{7 . 4 4}$ & - & 4.67 & $\mathbf{3 . 2 3}$ \\
Root Mean Square Error & - & 13.40 & $\mathbf{8 . 2 8}$ & - & 5.37 & $\mathbf{4 . 4 4}$ \\
Mean Fractional Bias & - & 0.04 & $\mathbf{0 . 0 1}$ & - & 0.31 & $\mathbf{0 . 0 7}$ \\
Mean Fractional Error & - & 0.18 & $\mathbf{0 . 1 1}$ & - & 0.52 & $\mathbf{0 . 3 8}$ \\
\hline
\end{tabular}

${ }^{\mathrm{a}}$ Units (except Mean Fractional Bias/Error are dimensionless) for MDA8 are ppb; for W126 are ppm-h.

${ }^{\mathrm{b}}$ L: Layers

(Fig. 6c-d). This indicates that the coarser vertical resolution may produce unrealistic meteorological conditions (boundary structure, wind fields, vertical mixing, etc) that result in stronger net subsidence of airmasses to the surface.

The impacts of horizontal resolution were also assessed by comparing SEN1 of MDA8 and W126 in the $60 \mathrm{~km} / 32$ layer and $12 \mathrm{~km} / 32$ layer grids (Fig. 6e-f). The finer horizontal resolution produces sharper gradients, and SEN1 of MDA8 in the $12 \mathrm{~km}$ grid is generally higher by $\sim 3-6 \mathrm{ppb}$ $(\sim 5-20 \%)$. A few regions (LA-San Diego, Seattle, Reno and the east ridge of the Central Valley) show lower SEN1, indicating differences at the local/urban scale that cannot be reflected in the coarse grid. The differences in W126 in the two grids range from -5 to $\sim 3 \mathrm{ppm}-\mathrm{h}(10-30 \%)$, and the $12 \mathrm{~km}$ SEN1 are lower over NV, central and southern coast of CA, western OR and southern ID. Overall the differences of sensitivities in $60 \mathrm{~km} / 18$ layer and $12 \mathrm{~km} / 32$ layer grids are $\sim 2.5 \mathrm{ppm}-\mathrm{h}$ and $\sim 4 \mathrm{ppb}$ for $\mathrm{W} 126$ and MDA8, respectively (Fig. 6g-h).

In general, impacts of resolution on SEN1 are much larger than those due to the NA emission perturbations. The impacts of NA anthropogenic emissions and grid resolution on SEN2 qualitatively reach similar conclusions as those for SEN1 (not shown in figures).

\subsection{Connecting extra-regional pollution with surface $\mathrm{O}_{3}$}

The results in Sect. 3.1 show that TBG significantly affects western US surface $\mathrm{O}_{3}$. To better understand the processes that link transported plumes to surface $\mathrm{O}_{3}$, we studied in detail the $\mathrm{O}_{3}$ sources at three sites (MBO, THD and South Coast (SC)) along the western US, and compared how $\mathrm{O}_{3}$ aloft at these sites impacted downwind surface $\mathrm{O}_{3}$ concentrations.

\subsubsection{Evaluation of model base simulation at sites}

Figure 7a compares the observed and modeled $\mathrm{O}_{3}$ time series at $\mathrm{MBO}$. Several high $\mathrm{O}_{3}$ episodes were observed, with hourly maxima over $80 \mathrm{ppb}$. The model captures most of the observed variability, with major discrepancies at the beginning and end of the study period (18-20 June and 12-14 July), when predicted boundary layer heights (PBLH) were highest (not shown). Erroneously high mixed layer heights, too strong downwind transport, and/or uncertainties in BCs are possible reasons for the overprediction. Statistics for all simulations indicate better performance in the $12 \mathrm{~km} / 32$ layer grid (except correlation $r$ ): $r$, mean bias, mean error, and RMSE are 0.37, $4.28 \mathrm{ppb}, 10.67 \mathrm{ppb}, 14.00 \mathrm{ppb}$, respectively, compared to these in the $60 \mathrm{~km} / 18$ layer simulation: 0.56 , $9.44 \mathrm{ppb}, 12.42 \mathrm{ppb}, 14.50 \mathrm{ppb}$.

The THD sonde data were binned to the 32 model layers and compared with the model simulations (Fig. 7c-e). The $12 \mathrm{~km}$ simulation captures much of the observed variability, including the strong episodes that occurred on 2224 June (Huang et al., 2010a) and 5-7 July, as well as clean periods (e.g., 2-4 July). In the lower free troposphere $\left(\sim 1.5-4 \mathrm{~km}\right.$ a.s.l.) mean $\mathrm{O}_{3}$ levels ranged from $<40 \mathrm{ppb}$ to $\sim 120 \mathrm{ppb}$ and concentrations $>40 \mathrm{ppb}$ are observed $65 \%$ $-80 \%$ of the times. Daily model performance statistics show $r$ values $>0.5$, RMSE $<20 \mathrm{ppb}$, and biases across all levels $<15 \mathrm{ppb}$. The model overpredicts $\mathrm{O}_{3}$ near the surface, consistent with the evaluations at the coastal AQS sites (Sect. 3.1.1), and in the upper troposphere, possibly due to the BCs. The $60 \mathrm{~km}$ simulation looks similar in terms of the general temporal variability, but overpredicts some periods (e.g., 28-29 June) due to the uncertainties in biomass burning emissions, and misplaced some vertical features (e.g., 9 July).

Modeled $\mathrm{O}_{3}$ at a CARB surface site $\mathrm{SC}$, (i.e., LA North Main Street: $34.1^{\circ} \mathrm{N},-118.3^{\circ} \mathrm{W}$, elevation $87 \mathrm{~m}$, http://www.arb.ca.gov/qaweb/site.php?s_arb_code=70087) was also compared with the observations (Fig. 7b). The strong $\mathrm{O}_{3}$ diurnal cycle indicates local $\mathrm{O}_{3}$ production, and again the $12 \mathrm{~km}$ simulation better captures the temporal variability, with higher correlation (0.61) than $60 \mathrm{~km}(0.25)$. The largest model discrepancies occur on $\sim 26$ June and $\sim 10$ July when the actual $\mathrm{O}_{3}$ levels were low. The $60 \mathrm{~km}$ simulation shows $\sim 20-30 \mathrm{ppb}$ higher positive biases than 
$12 \mathrm{~km}$, reflecting its incapability of capturing the nighttime minima due to the smoothed/diluted $\mathrm{NO}_{\mathrm{x}}$ emissions and uncertain meteorology in the coarse grid over the urban area. The strong diurnal variations seldom modified the simulated $\mathrm{O}_{3}$ vertical structures above $\sim 3 \mathrm{~km}$. Elevated $\mathrm{O}_{3}$ concentrations were predicted above 5-6 km around 24 June and 6-8 July, but they remained decoupled from the lower troposphere (not shown).

\subsection{2 $\mathrm{O}_{3}$ sensitivities to $\mathrm{BCs}$ and emissions at sites}

The time series of $\mathrm{O}_{3}$ sensitivities to: (1) $50 \%$ reduction in $\mathrm{BC} \mathrm{O}_{3}$ in three model resolutions; (2) the scaled NA anthropogenic emissions in the $60 \mathrm{~km} / 18$ layer grid; and (3) zeroing out biomass burning and biomass burning emissions in the $60 \mathrm{~km} / 18$ layer grid are shown at MBO $2.7 \mathrm{~km}$, THD $2.5 \mathrm{~km}$ and SC surface level (Fig. 8). Ozone levels at these altitudes are highly connected with downwind surface $\mathrm{O}_{3}$ levels as indicated in Sect. 3.3.3. Ozone sensitivities to BC $\mathrm{O}_{3}$ at THD and MBO show similar temporal variability and magnitude (10-40 ppb, with correlations of 0.6-0.8 depending on resolution), indicating that they are influenced by similar sources/synoptic flow conditions during this period. This supports the findings by Zhang et al. (2009) for spring 2006 when they found that both sites were affected by northern China emissions. The BCs used in analysis correctly reflect the major LRT episodes (22-24 June and 5-7 July), resulting in good model performance at THD and MBO. The uncertainty in the $\mathrm{BCs}$ is the major reason causing the $\mathrm{O}_{3}$ overprediction at both locations during 18-20 June and after 12 July. An additional high $\mathrm{O}_{3}$ period (30 June-4 July) at MBO (above the period mean level shown as the thin horizontal red line) is shown to be affected by the NA anthropogenic and biomass burning emissions. Impacts of biogenic emissions are overall slightly negative due to the $\mathrm{NO}_{\mathrm{x}}$ sensitive condition. $\mathrm{THD} \mathrm{O}_{3}$ at $2.5 \mathrm{~km}$ was intensively affected by northern CA wildfires, which led to $\mathrm{O}_{3}$ enhancements during 29-30 June and $\sim 10$ July (as indicated from the high sensitivity (up to $>50 \mathrm{ppb}$ ) to biomass burning emissions). Uncertainties in fire/biogenic emissions possibly caused the overprediction in $\mathrm{O}_{3}$ from the surface to $\sim 4 \mathrm{~km}$ (Fig. 7e). The impacts of BC $\mathrm{O}_{3}$ at $\mathrm{SC}$ are smaller due to the lower altitude, with a similar diurnal cycle as the total $\mathrm{O}_{3}$ concentrations. $\mathrm{SC} \mathrm{O}_{3}$ is less strongly affected by biomass burning than the other two locations, and the varied sensitivities to US anthropogenic emissions indicate the different photochemical regimes and meteorological conditions. The high positive sensitivities to anthropogenic and biogenic emissions after 10 July possibly caused the overprediction in $\mathrm{O}_{3}$ for this period.

\subsubsection{Connection of surface $\mathrm{O}_{3}$ and $\mathrm{O}_{3}$ aloft at previous times}

\section{Trajectories and the Impacting Probability (IP) metric}

The pathways of descending airmasses from MBO $2.7 \mathrm{~km}$, THD $2.5 \mathrm{~km}$ and SC $1.5 \mathrm{~km}$ ( top of the PBL, based on measurements of daily maximum PBLH at Pasadena in spring 2010 ranging from $\sim 600-1800 \mathrm{~m}$, Newman et al., 2012) were studied by two-day forward trajectories (calculated hourly) based on the $12 \mathrm{~km}$ WRF meteorology. The trajectories originating from $\mathrm{MBO}$ at all night times (to minimize the local contributions and to study the influences of free troposphere air which typically has higher $\mathrm{O}_{3}$ concentrations) during the 29-day period were calculated, together with the forward trajectories originating from THD $2.5 \mathrm{~km}$ and SC $1.5 \mathrm{~km}$ at all day times during the studied period. Daytime trajectories were chosen because of the higher $\mathrm{O}_{3}$ and the dominance of on-shore flows during the daytime (Fig. S4). Most of the trajectories from THD travel towards CA, ID, OR and $\mathrm{NV}$ at altitudes below $\sim 1.5 \mathrm{~km}$, whereas the trajectories from SC travel towards the southern CA air basin, southern $\mathrm{NV}$ and Mexico at $\sim 0.5-1 \mathrm{~km}$. Airmasses from MBO impacted OR, WA, ID and northern CA at $0.5-2 \mathrm{~km}$.

To quantify the likelihood of transported air mixing with local air pollution, we calculated the Impacting Probability (IP) metric for transported air, defined in Eq. (11):

$\begin{aligned} \text { IP }(\text { dimensionless })= & \text { (number of trajectory points at a } \\ & \text { specific time lower than local PBLH)/ } \\ & \text { (number of all points at the same } \\ & \text { time) }\end{aligned}$

The IP metric is an indicator of how often the entrainment of transported airmasses occurs at a specific time, and was calculated at all local daytimes (Table 5). The MBO and THD airmasses show the highest chance to be entrained into the boundary layer in the early afternoon (i.e., $\mathrm{IP}=0.66$ and 0.34 , respectively, at $\sim 03: 00$ p.m. PDT), when the PBL is deep and well mixed over many regions. The overall higher IP for MBO than those for THD is because most of the impacted regions downwind of $\mathrm{MBO}$ have higher topography, as explained by Wigder et al. (2012). The IP values for airmasses $1.5 \mathrm{~km}$ above SC demonstrate a flatter shape than those for THD and MBO, and are greater than 0.5 during 09:00 a.m.04:00 p.m. PDT. This reflects that on-shore winds and boundary layer growth quickly connect $1.5 \mathrm{~km}$ airmasses above SC with the surface regions.

\section{Adjoint sensitivity: areas of influence}

We calculated adjoint sensitivities to surface $\mathrm{O}_{3}$ at receptor regions to further explore the impacts of transport/subsidence of airmasses on surface $\mathrm{O}_{3}$. The STEM adjoint sensitivity 


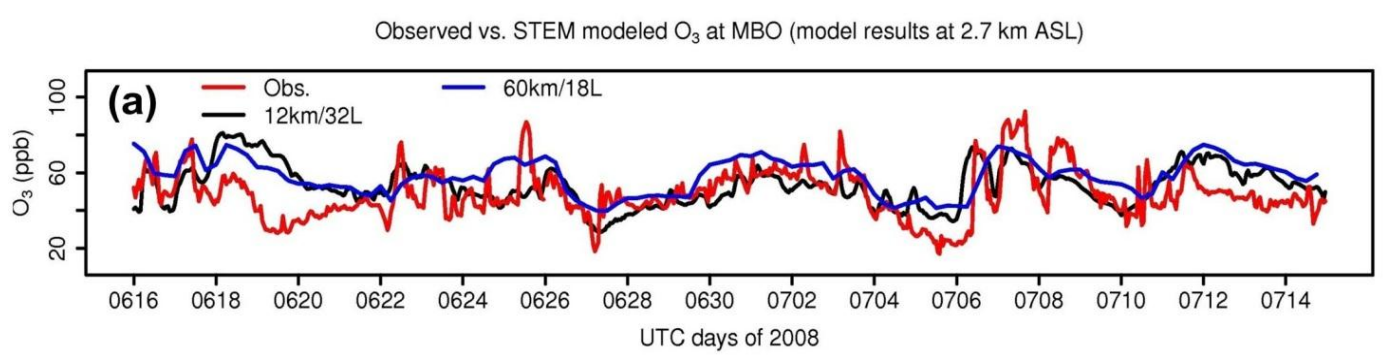

Observed vs. STEM Modeled $\mathrm{O}_{3}$ at SC
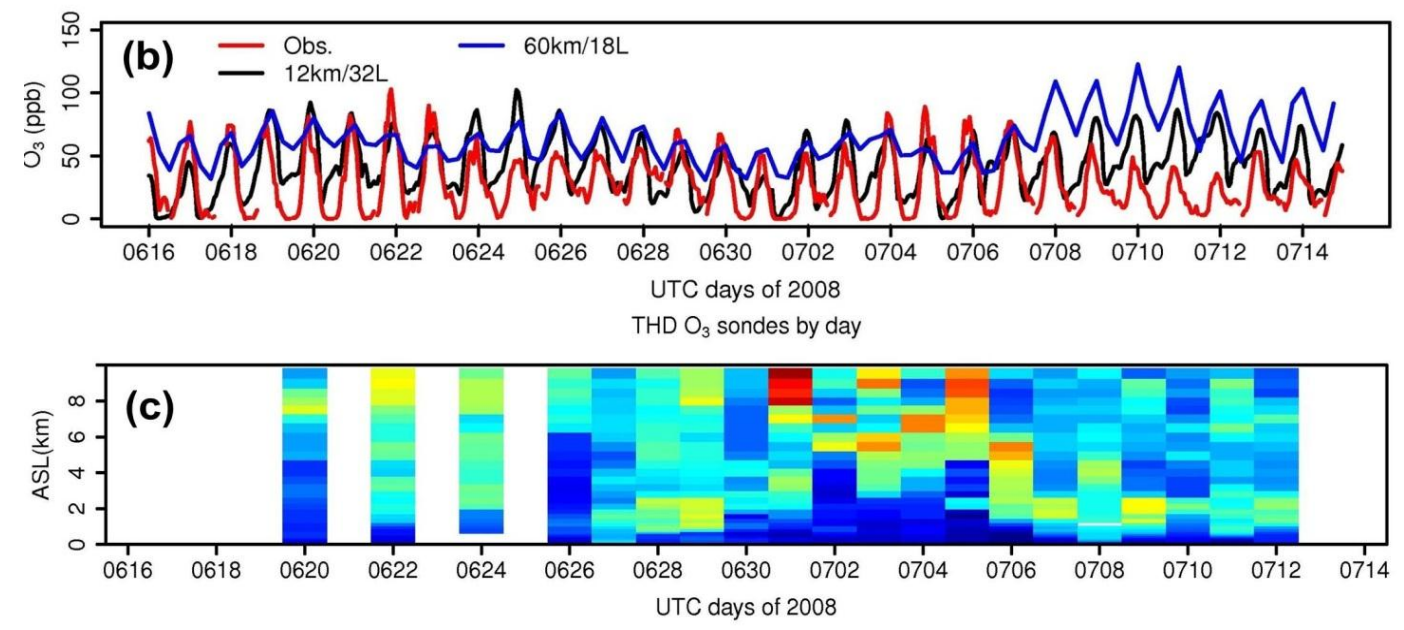

STEM $12 \mathrm{~km}$ modeled $\mathrm{THD} \mathrm{O}_{3}$ at sounding times by day

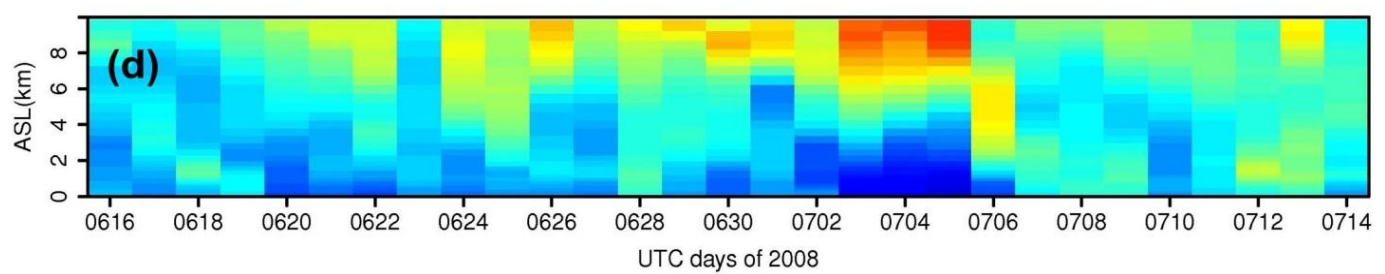

STEM $60 \mathrm{~km}$ modeled THD $\mathrm{O}_{3}$ at $18 \mathrm{UTC}$ by day

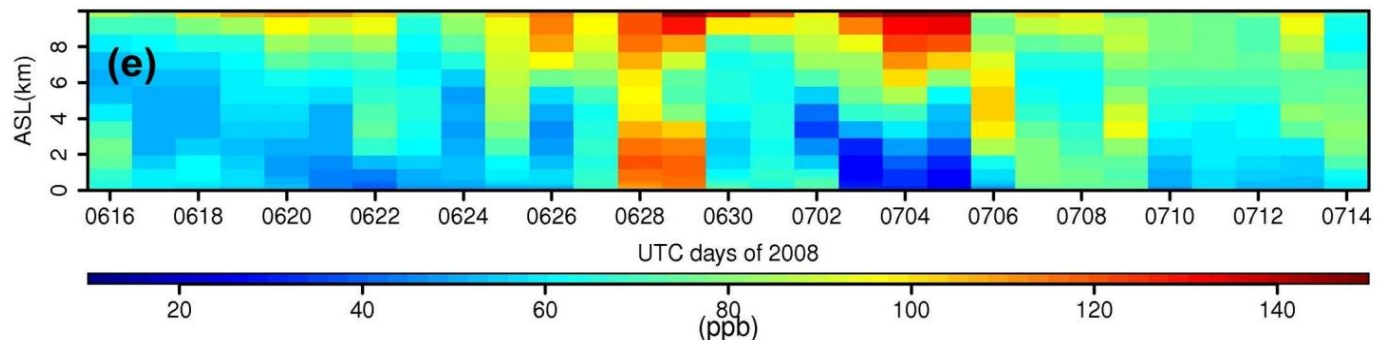

Fig. 7. (a) Observed and STEM modeled $\mathrm{O}_{3}$ time series at the MBO site. The model results were extracted from the layer(s) that matched the actual MBO altitude. (b) Observed and STEM modeled $\mathrm{O}_{3}$ time series at SC surface site. (c) Trinidad Head (THD) daily $\mathrm{O}_{3}$ sonde data during the studied period, binned into 32 model layers; (d) STEM $12 \mathrm{~km}$ modeled THD $\mathrm{O}_{3}$ daily vertical profiles at ozonesondes times during the same period; (e) STEM $60 \mathrm{~km}$ modeled THD $\mathrm{O}_{3}$ daily vertical profiles at 18:00 UTC during the same period.

analysis has demonstrated advantages over trajectory analysis and previous correlation-based analysis (e.g., Huang et al., 2010a, b) in that it includes horizontal transport, vertical mixing and chemistry processes in the calculations (Sandu et al., 2005). The selected northwestern US receptor (NWR)
(4250 grids) and the southern CA receptor (SCR) (1200 grids) (areas in the blue line boxes in Fig. 9a-b) were shown to be affected by the transported airmasses over MBO, THD or SC in the trajectory and correlation analyses (Huang et al., $2010 \mathrm{~b})$. The $\mathrm{O}_{3}$ adjoint sensitivities $\left(\lambda\left[\mathrm{O}_{3}\right]\right)$ were calculated 
$\mathrm{O}_{3}$ reductions in response to perturbations in $\mathrm{BC}_{3}$ and emissions @ $\mathrm{MBO}$

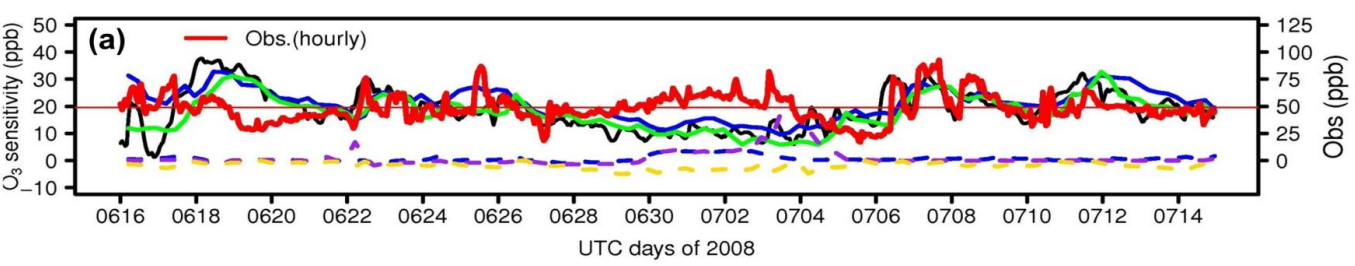

$\mathrm{O}_{3}$ reductions in response to perturbations in $\mathrm{BC}_{3}$ and emissions @ THD 2.5km

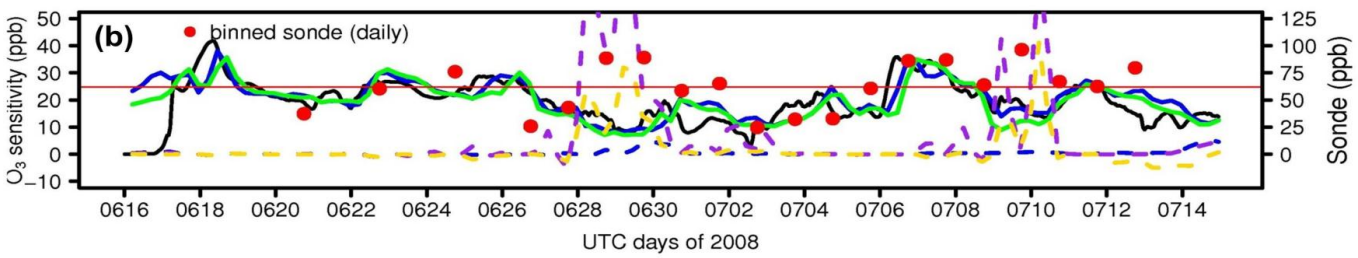

$\mathrm{O}_{3}$ reductions in response to perturbations in $\mathrm{BC}_{3}$ and emissions @ SC surface

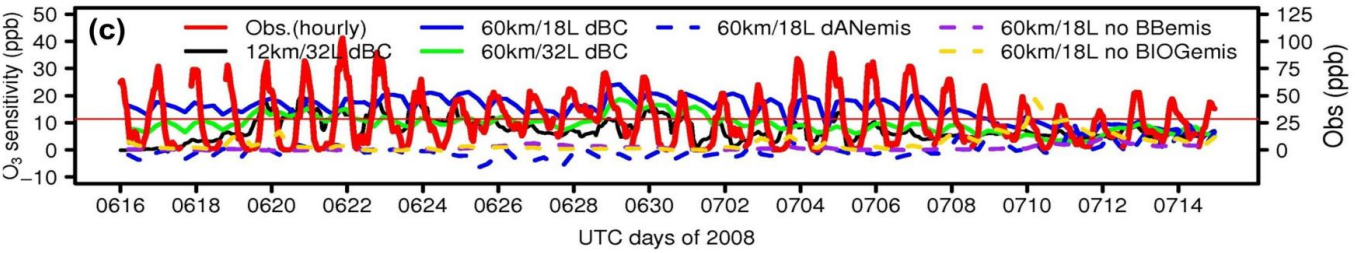

Fig. 8. Time series of $\mathrm{O}_{3}$ reductions at (a) MBO $2.7 \mathrm{~km}$ a.s.1.; (b) THD $2.5 \mathrm{~km}$ a.s.1.; and (c) SC lowest level, in response to $50 \%$ perturbations in $\mathrm{O}_{3}$ boundary conditions ( $\mathrm{dBC}$ ), reduction in US anthropogenic emissions (dANemis) and zeroing out the North American biomass burning (BBemis) and biogenic emissions (BIOGemis). Time series of observations at the corresponding altitude and their period mean are drawn as the red thick and horizontal thin lines, respectively.

$49 \mathrm{~h}$ backward in time from 00:00 UTC of each day, and the areas of influence for each case were averaged to produce the monthly mean areas of influence with 49 time steps, which are used for discussions below.

Figure $9 \mathrm{a}-\mathrm{b}$ show the vertically-integrated $\lambda\left[\mathrm{O}_{3}\right]$ averaged over the previous day daytimes calculated on the $12 \mathrm{~km}$ grid. They show the locations that have the biggest impact on next day surface $\mathrm{O}_{3}$ at NWR and SCR, respectively. Surface $\mathrm{O}_{3}$ in the NWR at 00:00 UTC is sensitive to previous day $\mathrm{O}_{3}$ concentrations over a large geographical region that extends over hundreds of kilometers (Fig. 9a). The western extent of the influence area helps identify the multiple transport pathways that bring eastern Pacific airmasses into this region, which are controlled by the moving Pacific-high pressure systems from June to July. Surface $\mathrm{O}_{3}$ over southern $\mathrm{CA}$ is shown to be sensitive to $\mathrm{O}_{3}$ in the Central Valley, and the near-shore areas along the central and south coast on the previous daytime, which indicates the impacts of inter-basin transport and sea breezes (Fig. 9b). Returning airmasses from NV to the northern Central Valley in the previous daytime also impact southern CA in the following day.

Similar adjoint sensitivity analysis was also done on the $60 \mathrm{~km} / 18$ layer grid. The results are qualitatively similar, but are much smoother than those for the $12 \mathrm{~km}$ analysis (Fig. S5).

\section{Adjoint sensitivity: surface $\mathrm{O}_{3}$ sensitivity to $\mathrm{O}_{3}$ at selected sites at earlier times}

To connect the results from forward trajectory analysis conducted for MBO, THD and SC, we plot the time-height curtain of the $12 \mathrm{~km}$-calculated $\lambda\left[\mathrm{O}_{3}\right]$ at these sites (i.e., surface $\mathrm{O}_{3}$ sensitivity to $\mathrm{O}_{3}$ at these sites through time), normalized by the number of receptor grids. Figure $9 \mathrm{c}-\mathrm{d}$ illustrates the temporal evolution of $\lambda\left[\mathrm{O}_{3}\right]$ at MBO and THD with respect to the NWR surface $\mathrm{O}_{3}$ at final time. Two hotspots are found in the MBO plot (Fig. 9c): within the boundary layer $1-5 \mathrm{~h}$ before the final time; and in the free troposphere 10$15 \mathrm{~h}$ backwards in time. The THD plot (Fig. 9d) also shows two hotspots: within the boundary layer $1-5 \mathrm{~h}$ backwards in time; and $1.5-2.5 \mathrm{~km}$ in free troposphere $25-30 \mathrm{~h}$ backwards in time. These results indicate that surface $\mathrm{O}_{3}$ at NWR is affected by both local production (close to the final time) and $\mathrm{O}_{3}$ in the free troposphere at $\mathrm{MBO}$ and THD.

The temporal evolution of $\lambda\left[\mathrm{O}_{3}\right]$ at $\mathrm{SC}$ for SCR is shown in Fig. 9e. The gradients at SC are strongest in the first $10 \mathrm{~h}$ before the final time, extend out to $30 \mathrm{~h}$ before, and are highest below $2 \mathrm{~km}$ a.s.l. These results indicate that the transport of $\mathrm{O}_{3}$ at $\mathrm{SC}$ to the SCR surface involve transport above the nocturnal and marine boundary layers and subsequent entrainment into the daytime boundary layer. The transport most 
$\lambda \mathrm{O}_{3}$ previous DT mean, all levels integrated

(a)

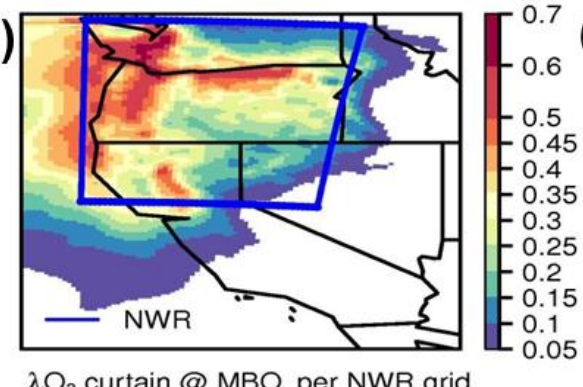

$\lambda \mathrm{O}_{3}$ curtain @MBO,per NWR grid
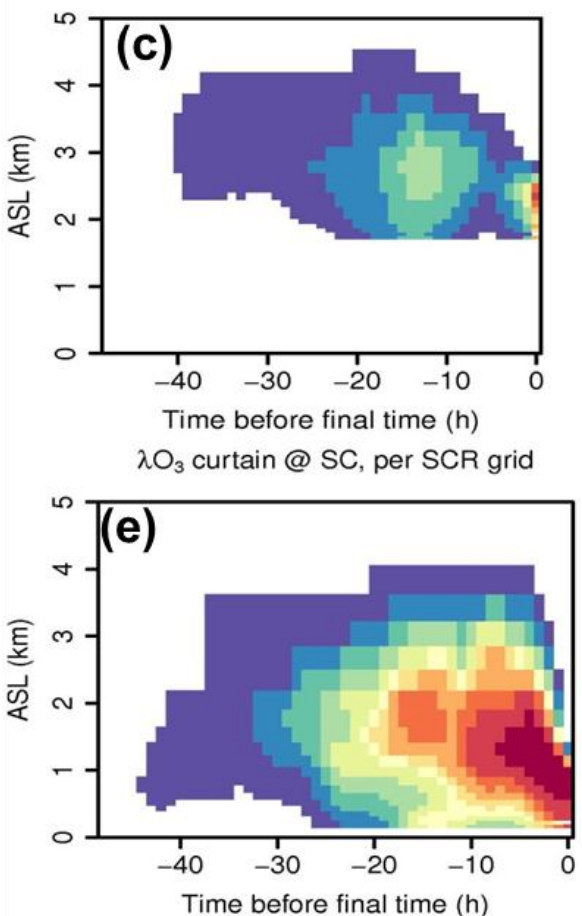

$\lambda \mathrm{O}_{3}$ previous $\mathrm{DT}$ mean, all levels integrated

(b)
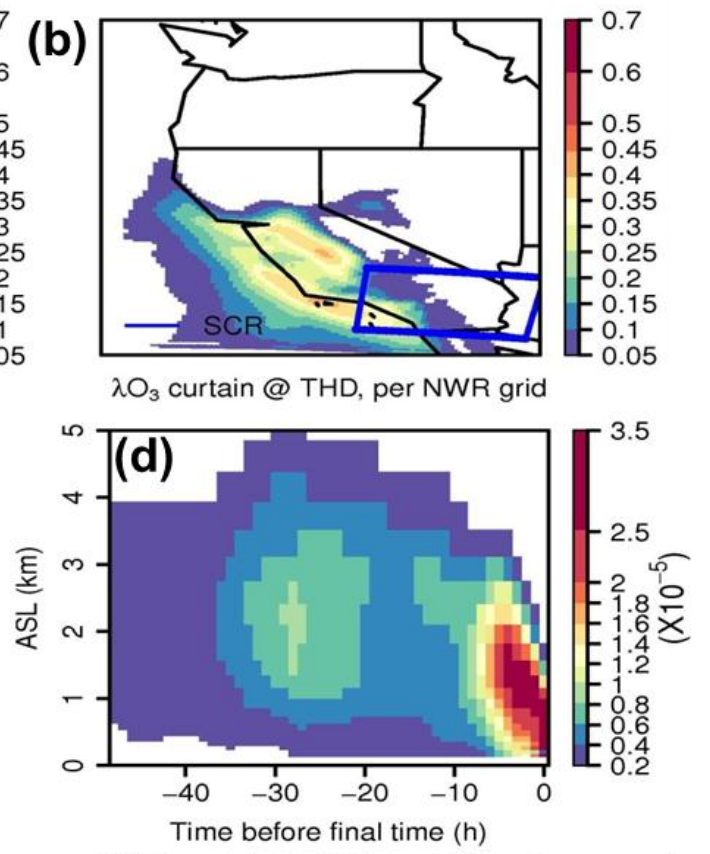

$5 \mathrm{X \lambda O}_{3}$ curtain @ THD, per SCR grid

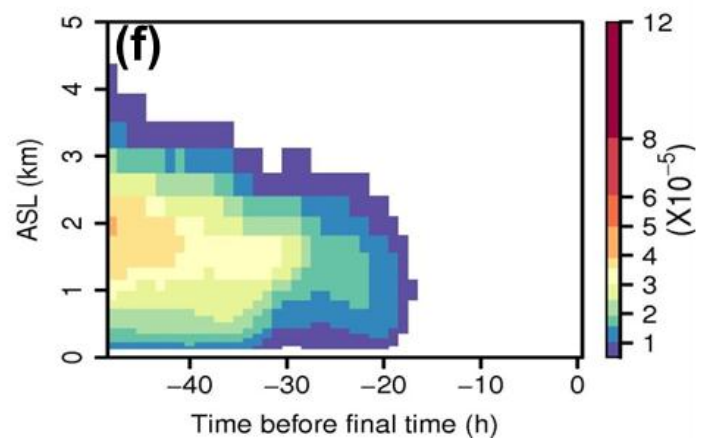

Fig. 9. Previous daytime-mean $\mathrm{O}_{3}$ adjoint sensitivities $\left(\lambda\left[\mathrm{O}_{3}\right]\right)$ in (a) NWR case and (b) SCR case, all levels integrated. Areas within the blue lines indicate the receptor regions. (c) $\lambda\left[\mathrm{O}_{3}\right]$ time-height curtain at MBO, NWR case; (d) $\lambda\left[\mathrm{O}_{3}\right]$ time-height curtain at THD, NWR case; (e) $\lambda\left[\mathrm{O}_{3}\right]$ time-height curtain at $\mathrm{SC}$, SCR case; (f) $\lambda\left[\mathrm{O}_{3}\right]$ time-height curtain at THD, SCR case. (c-e) were normalized by receptor grid numbers, note the different color scales for NWR and SCR cases.

strongly affects $\mathrm{O}_{3}$ over downwind areas in the next 1-2 days. Ozone in the free troposphere over THD also influences the surface $\mathrm{O}_{3}$ levels at SCR (Fig. 9f) with a much weaker intensity (the scale $\times 5$ ). The maximum sensitivities are found $30-40 \mathrm{~h}$ backward in time at $1-2 \mathrm{~km}$ a.s.l., the height at which the plumes enter northern CA, move through the Central Valley, and reach the surface SCR. Again these results are consistent with the trajectory analysis.

Adjoint sensitivities in the $60 \mathrm{~km} / 18$ layer grid cannot represent these processes as clearly as in the $12 \mathrm{~km}$ grid (Fig. S5).

\subsection{Case study: DA during a LRT episode}

Results from Sects. 3.1-3.3 show that elevated pollution levels over the eastern Pacific can be transported inland and entrained into the PBL in summer. Therefore, improving modeled $\mathrm{O}_{3}$ concentrations over the eastern Pacific can reduce uncertainties in modeled surface pollution levels over the western US. In this section, we explore how well existing $\mathrm{O}_{3}$ observations can constrain modeled surface $\mathrm{O}_{3}$ concentrations using DA and reduce these uncertainties in the estimated TBG contributions. Since model resolution is critical for reflecting the subsidence processes (Sects. 3.2.2 and 3.3.3), all DA cases were performed in the $12 \mathrm{~km} / 32$ layer grid. 
(a) $\mathrm{MBO}(2.7 \mathrm{~km})$ and THD (2.5km) back-traj on 0706 18UTC, overlaid log. fire emis.on 0701 00UTC

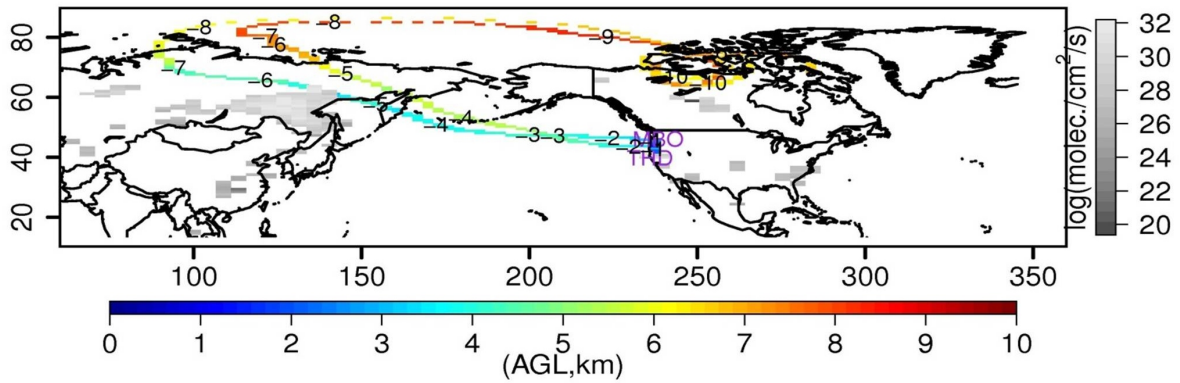

(b) TES CO $(06 / 30-07 / 01)$

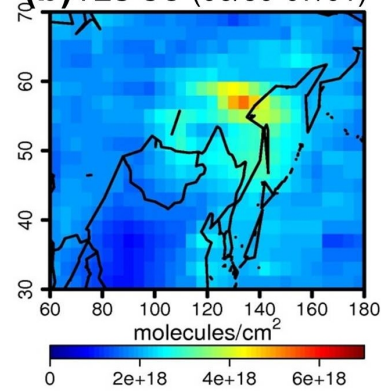

(c) TES O $3(07 / 02-07 / 05)$

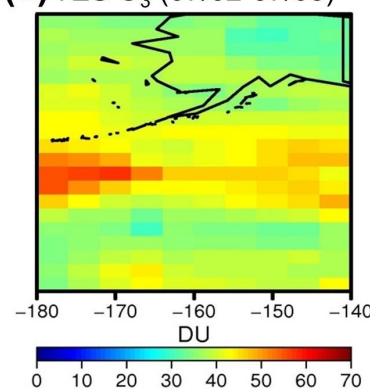

(e) $12 \mathrm{~km}$ WRF Winds $(\mathrm{m} / \mathrm{s})$ ot $\sim 2500 \mathrm{~m} \mathrm{AGL}$

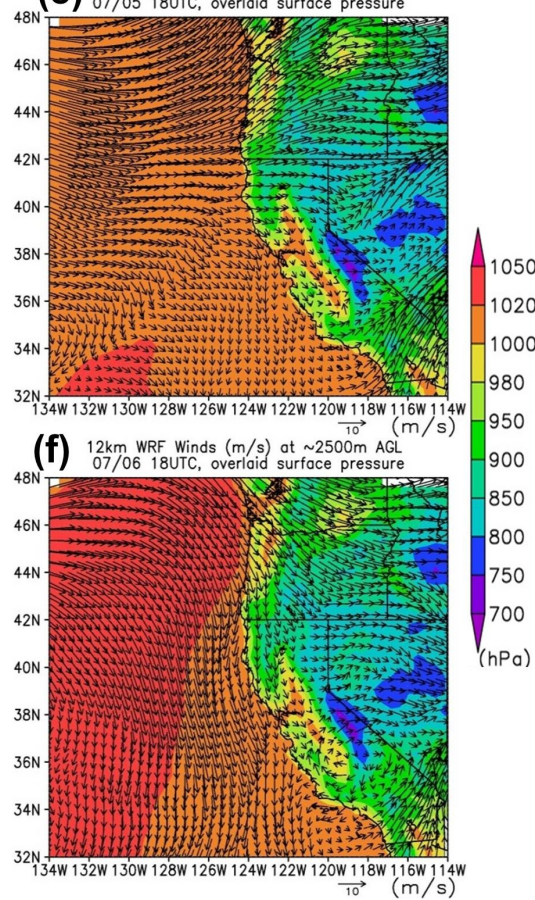

Fig. 10. (a) MBO and THD back-trajectories ending at 18:00 UTC on 6 July, colored by the travelling heights (in km, a.g.l.), based on the $60 \mathrm{~km}$ WRF-simulated wind fields. Negative numbers along the trajectories indicate days back from the ending time. RAQMS fire emissions $\left(\log \left(\right.\right.$ molecules $\left.\left.\mathrm{cm}^{-2} / \mathrm{s}\right)\right)$ at 00:00 UTC, 1 July are overlaid with grey color scale. TES Level 3 nadir (b) total CO columns on 30 June-1 July and tropospheric $\mathrm{O}_{3}$ columns on (c) 2-5 July and (d) 4-7 July. $12 \mathrm{~km}$ WRF-simulated wind fields ( $\sim 2.5 \mathrm{~km}$ a.g.l.) overlaid on the surface level pressure (SLP, hPa) at 18:00 UTC on (e) 5 July and (f) 6 July.

We selected 5-7 July as a representative LRT episode for a case study, during which time the northwestern US began to be impacted by extra-regional emissions. As indicated in Fig. 7-8, the transported plumes started to influence $\mathrm{O}_{3}$ levels at THD $2.5 \mathrm{~km}$ and MBO $2.7 \mathrm{~km}$ on 5-6 July. Twelve-day back-trajectories (Fig. 10a) based on the $60 \mathrm{~km}$ WRF meteorology from these two locations at 18:00 UTC on 6 July are colored by travelling heights (in kma.g.l.), and they show similar transport pathways. About eleven days before the airmasses were over the Arctic $\left(80^{\circ} \mathrm{N}\right.$ over Canada) at 9-10 km. Then they were transported over Siberia (where the wildfires occurred as indicated by the overlaid RAQMS fire emissions in grey color scale at 00:00 UTC on 1 July) in the upper troposphere, descended into the mid-troposphere over northeast Asia and across the Pacific, while continuing to descend, and finally reached the western US.

The transport of pollutants during this period was observed by TES. In Fig. 10b-d, we matched the TES total CO and tropospheric $\mathrm{O}_{3}$ columns during this period. Strongly enhanced CO columns (up to $5-6 \times 10^{18}$ molecules $\mathrm{cm}^{-2}$ ) were observed on 30 June-1 July near the fire sources in northeastern Asia. Enhanced $\mathrm{O}_{3}$ tropospheric columns (up to 60-70 DU) were seen during 2-5 July in the middle of the Pacific at 40$50^{\circ} \mathrm{N}$. After $\sim 5-7$ days of transport from the Russian fire events (4-7 July), enhanced $\mathrm{O}_{3}$ columns were seen over the western US (up to 60-70 DU).

To discuss the impacts of this event on inland air quality, Fig. 10e-f show the $12 \mathrm{~km}$ WRF-predicted flow fields (overlaid on WRF-predicted color-shaded surface level pressure (SLP)) on 5 July and 6 July, 18:00 UTC at $\sim 2.5-3 \mathrm{~km}$ a.g.l. On 5 July, winds were mostly westerly, directly bringing the offshore pollution inland. On the following day, the winds shifted towards the south and the on-shore winds affected northern CA.

\subsubsection{Discrepancies between the model a priori and OMI/TES retrievals}

At $\sim 22: 00$ UTC on 5 July, Aura overpassed the eastern Pacific when the TES special observations and OMI measurements were made (Fig. 11a). The model a priori (without assimilation) at this time is compared with the selected (criteria of selecting TES and OMI data for DA is described in Table 3) satellite retrievals in the DA domain (a subset of the $12 \mathrm{~km} / 32$ layer grid covering WA, OR and northern CA, Fig. 11a). The a priori agrees fairly well with the satellite retrievals, and is overall underpredicted compared to OMI, over a wide area of the eastern Pacific north of $42^{\circ} \mathrm{N}$. Compared to TES, the a priori overpredicts $\mathrm{O}_{3}$ in the upper troposphere 

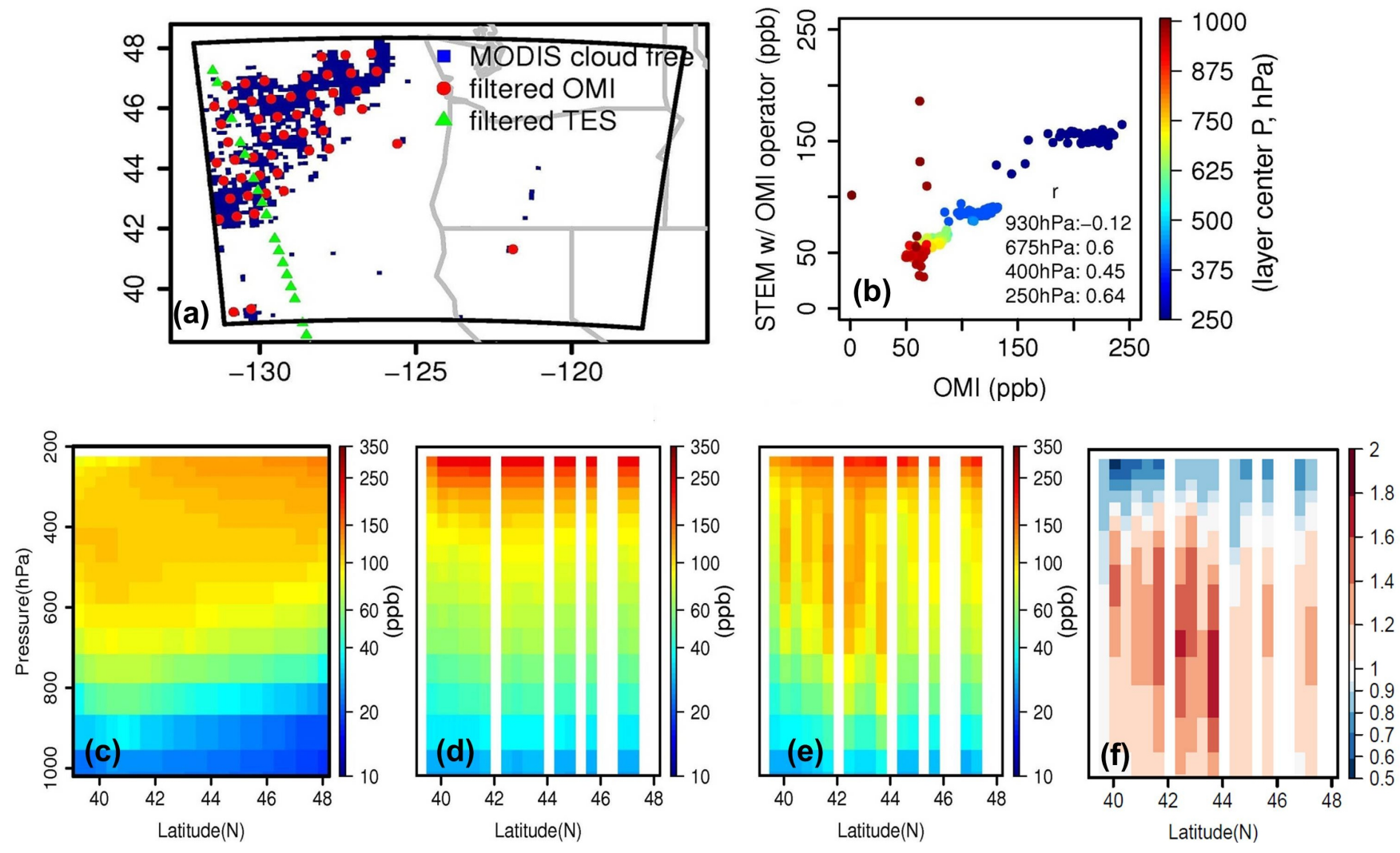

Fig. 11. (a) The data assimilation domain in $12 \mathrm{~km} / 32$ layer grid and the locations where the selected (based on the criteria described in Table 3) TES and OMI measurements were made. (b) Scatter plot of STEM a priori (with OMI observation operator) vs. OMI retrieval, colored by pressure at OMI layer centers (hPa). (c) STEM a priori (raw data) along the TES orbit at the overpass time, interpolated into the TES pressure levels; (d) STEM a priori (with TES observation operator) along the TES orbit; (e) TES $\mathrm{O}_{3}$ nadir retrieval; (f) the ratios of (e) $/(\mathbf{d})$.

Table 5. The "IP" metric for three locations, at all local day times during 16 June-14 July 2008.

\begin{tabular}{|c|c|c|c|c|c|c|c|c|c|c|c|c|c|c|}
\hline \multicolumn{2}{|c|}{ Pacific Daylight Times } & \multirow{2}{*}{$\begin{array}{r}08: 00 \\
0.13\end{array}$} & \multirow{2}{*}{$\begin{array}{r}09: 00 \\
0.17\end{array}$} & \multirow{2}{*}{$\begin{array}{r}10: 00 \\
0.22\end{array}$} & \multirow{2}{*}{$\begin{array}{r}11: 00 \\
0.39\end{array}$} & \multirow{2}{*}{$\begin{array}{r}12: 00 \\
0.54\end{array}$} & \multirow{2}{*}{$\begin{array}{r}13: 00 \\
0.61\end{array}$} & \multirow{2}{*}{$\begin{array}{r}14: 00 \\
0.65\end{array}$} & \multirow{2}{*}{$\begin{array}{r}15: 00 \\
0.66\end{array}$} & \multirow{2}{*}{$\begin{array}{r}16: 00 \\
0.67\end{array}$} & \multirow{2}{*}{$\begin{array}{r}17: 00 \\
0.65\end{array}$} & \multirow{2}{*}{$\begin{array}{r}18: 00 \\
0.60\end{array}$} & \multirow{2}{*}{$\begin{array}{r}19: 00 \\
0.50\end{array}$} & \multirow{2}{*}{$\begin{array}{r}20: 00 \\
0.20\end{array}$} \\
\hline Trajectory & MBO $2.7 \mathrm{~km}$ & & & & & & & & & & & & & \\
\hline starting & THD $2.5 \mathrm{~km}$ & 0.12 & 0.15 & 0.21 & 0.26 & 0.29 & 0.33 & 0.34 & 0.34 & 0.33 & 0.32 & 0.27 & 0.21 & 0.10 \\
\hline locations & $\mathrm{SC} 1.5 \mathrm{~km}$ & 0.47 & 0.57 & 0.59 & 0.58 & 0.58 & 0.55 & 0.52 & 0.54 & 0.51 & 0.49 & 0.48 & 0.40 & 0.26 \\
\hline
\end{tabular}

and underpredicts in the lower/mid-troposphere. The highest negative biases occur at $500-900 \mathrm{hPa}(\sim 1-5 \mathrm{~km})$ south of $44^{\circ} \mathrm{N}$. Note that the discrepancies between satellite and model are determined by both model performance and the retrieval method/quality.

To discuss how the model biases (with respect to the satellite retrievals) over the eastern Pacific might impact surface $\mathrm{O}_{3}$ over the NWR region (defined in Sect. 3.3.3), we plot the adjoint sensitivities $\lambda\left[\mathrm{O}_{3}\right]$ along the TES and OMI sampling locations at the Aura overpass time (Fig. 12a;c). These sensitivities show that surface $\mathrm{O}_{3}$ over the NWR $\sim 30 \mathrm{~h}$ after the Aura overpass time (00:00 UTC, 7 July) was most sensitive to the $\mathrm{O}_{3}$ concentrations at $\sim 2-4 \mathrm{~km}$ at TES and OMI sampling locations. The magnitudes of $\lambda\left[\mathrm{O}_{3}\right]$ at the OMI sampling locations are overall higher than those at TES, possibly due to the wider horizontal coverage of samples and the wind fields on this day. These findings are different from the conclusions by Zoogman et al. (2011) over urban regions, where the local production dominates and the $\mathrm{O}_{3}$ production efficiency is most sensitive to PBL $\mathrm{O}_{3}$. The two-day forward trajectories originating at the Aura overpass time from TES sampling locations at $4 \mathrm{~km}$ (colored by traveling heights) demonstrate that airmasses originating south of $44^{\circ} \mathrm{N}$, where the highest discrepancies between the a priori and TES retrievals occur, rarely reached inland areas. In contrast, twoday forward trajectories originating at the same time from OMI sampling locations at $\sim 2 \mathrm{~km}$ impacted broad inland areas.

Similar analyses were conducted at THD (Fig. 12e-f), which indicates that airmasses at $\sim 2-5 \mathrm{~km}$ at the sonde 
(a) $\lambda \mathrm{O}_{3}$ along TES orbit (22UTC)

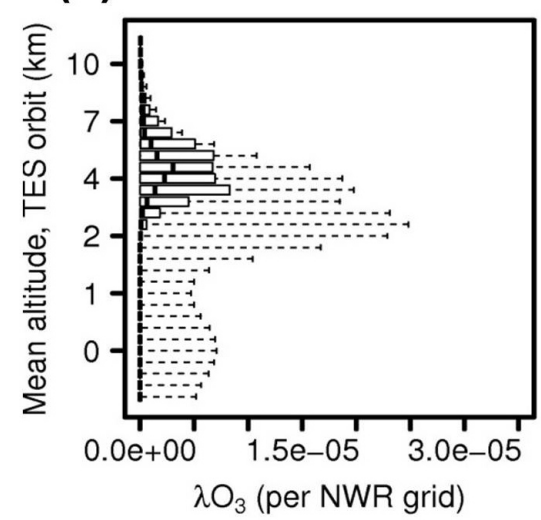

(c) $\lambda \mathrm{O}_{3}$ along $\mathrm{OMI}$ orbit (22UTC)

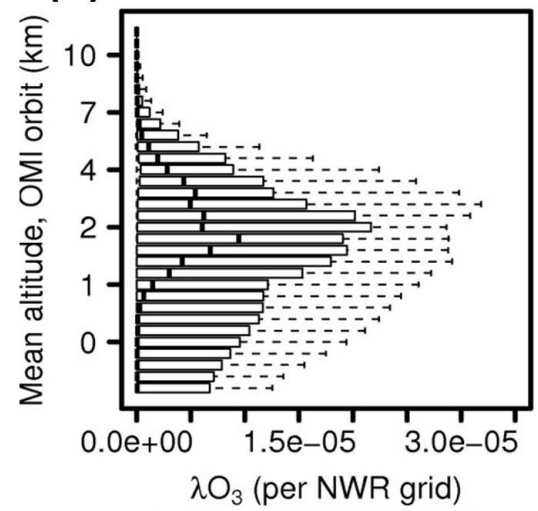

(e) $\lambda \mathrm{O}_{3}$ at THD (19UTC)

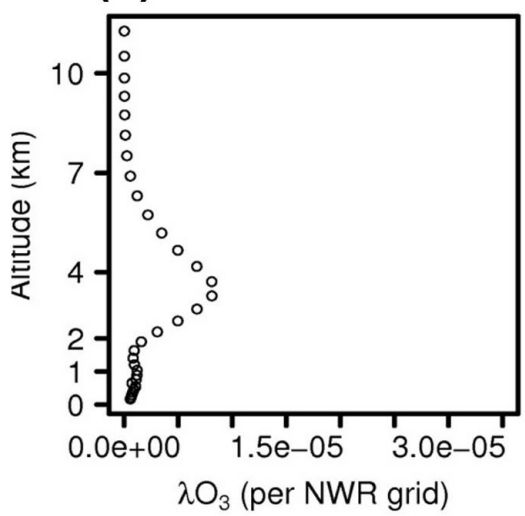

(b)Forw traj, TES orbit (22UTC,4km)

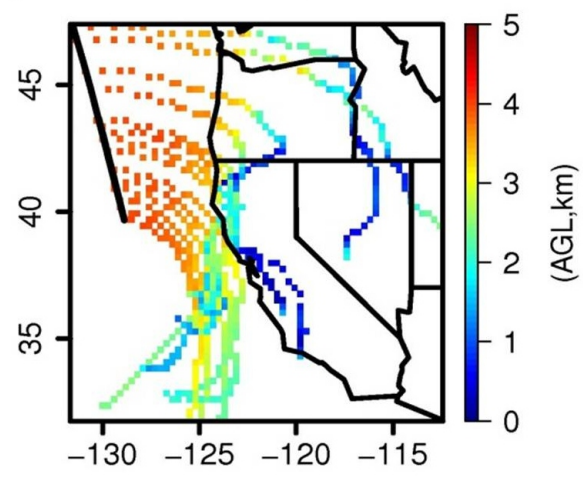

(d) Forw traj, OMI orbit (22UTC,2km)

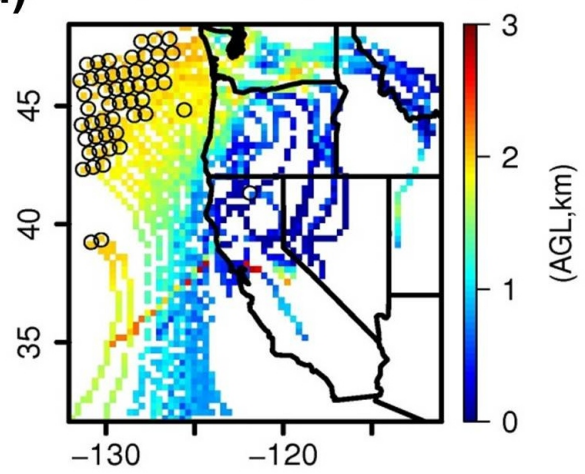

(f)Forw traj, THD (19UTC,2-5km)

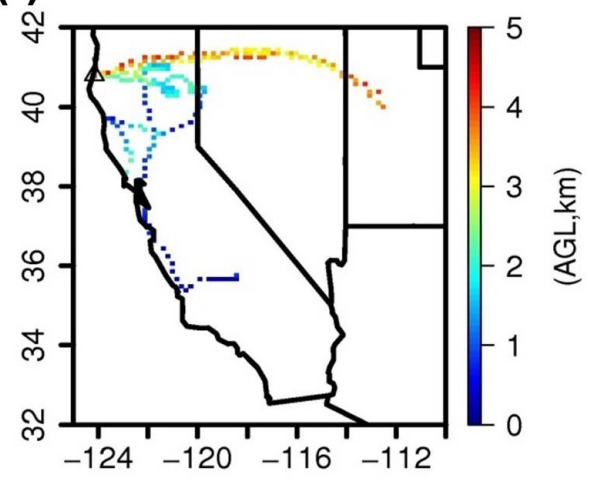

Fig. 12. Vertical profiles of adjoint $\lambda\left[\mathrm{O}_{3}\right]$ at 22:00 UTC on 5 July at the selected (a) TES and (c) OMI sampling locations; and (e) at THD at 19:00 UTC on July 5, shown as boxplots (minimum, 1st Quantile, median, 3rd Quantile and extreme). Receptor/final time is NWR/00:00 UTC on 7 July. Forward trajectories originating at the selected (b) TES ( $\sim 4 \mathrm{~km})$ and (d) OMI ( $2 \mathrm{~km})$ sampling locations at 22:00 UTC on 5 July; and (e) at THD $(2,3,4,5 \mathrm{~km})$ at 19:00 UTC on 5 July.

launch time ( $\sim$ 19:00 UTC on 5 July) had the strongest impacts on $\mathrm{O}_{3}$ over downwind areas in northern Central Valley on the following day, with the maximum $\lambda\left[\mathrm{O}_{3}\right]$ close to the magnitude of the monthly mean (Fig. 9d, the hot spot $\sim 30 \mathrm{~h}$ before the final time).

\subsubsection{Data assimilation results}

\section{Assimilation impacts at the surface}

Figure 13a-b show the modeled daytime-mean surface $\mathrm{O}_{3}$ during the 30-h assimilation window, before and after assimilating the available surface (AQS, CASTNET and MBO) 
observations (Case AS). A 54-h assimilation window (ending at 00:00 UTC on 8 July) was also tested but did not show significant differences for the first $30 \mathrm{~h}$ from Case AS. The AQS observations were assimilated from the model surface level, while CASTNET and MBO (located at higher altitudes) observations were assimilated from the model layer(s) that matched their actual altitudes. These observations are overlaid on the plots, most of which are located in northern CA. The a priori generally captures the observed $\mathrm{O}_{3}$ magnitudes over WA and OR, and underestimates $\mathrm{O}_{3}$ over most northern CA regions, where active biomass burning occurred during this time. In another case, we assimilated the available surface $\mathrm{AQS} \mathrm{NO}_{2}$ measurements and controlled $\mathrm{NO}_{\mathrm{x}}$ emissions by using a 24-h assimilation window (method details are described in Chai et al., 2009). Largest adjustment in $\mathrm{NO}_{\mathrm{x}}$ emissions occurred in northern CA (Fig. S6), reflecting the high uncertainties in biomass burning emissions that may lead to the $\mathrm{O}_{3}$ biases in the a priori. After assimilating surface observations, surface $\mathrm{O}_{3}$ over northern CA increases substantially (mostly by $5-10 \mathrm{ppb}$, but up to 10-20 ppb, Fig. 13c). Errors (error $=\mid$ modeled-observed $\mid$ ) at these observational sites are overall reduced after the assimilation (Table 6), with highest improvement over northern CA due to the largest discrepancies of the a priori and the dense number of observations.

Figure $13 \mathrm{~d}-\mathrm{f}$ show the differences of daytime-mean surface $\mathrm{O}_{3}$ before and after assimilating vertical profiles from TES (Case AT), OMI (Case AO) and THD sonde (Case $\mathrm{AD}$ ), respectively. The effects of assimilating vertical profiles modified daytime-mean surface $\mathrm{O}_{3}$ by $< \pm 0.5 \mathrm{ppb}$, with the major differences over WA and OR as well as near the sampling locations. The errors for daytime-mean $\mathrm{O}_{3}$ at the available surface sites were overall slightly reduced $(<0.2 \mathrm{ppb}$, Table 6). The limited changes in surface $\mathrm{O}_{3}$ compared to those in Case AS reflect the lack of spatiotemporal resolution for the assimilated vertical profiles.

We also assimilated surface observations and vertical profiles together (Cases AST, ASO and ASD for adding TES, OMI, and THD sonde, respectively). The differences of daytime-mean surface $\mathrm{O}_{3}$ between these cases and Case AS reflect the effects of adding $\mathrm{O}_{3}$ vertical profiles into the assimilation (Fig. 13g-i). Daytime-mean surface $\mathrm{O}_{3}$ over WA and OR increase slightly due to the underestimated $\mathrm{O}_{3}$ in mid-altitude offshore, and drop by up to $2-3 \mathrm{ppb}$ in northern CA, different from the features shown in Fig. 13d-f. The changes in errors for these cases are within $\sim \pm 2 \mathrm{ppb}$ and are overall positive (Table 6), indicating the competing/conflicting effects of assimilating the observations taken from different platforms/regions that may be due to retrieval uncertainties and model vertical structure (details in a following section of "Estimation of the uncertainties in satellite retrievals").

\section{Assimilation impacts in the vertical}

To demonstrate how the assimilation cases modified the $\mathrm{O}_{3}$ vertical distributions, we plotted the $\mathrm{O}_{3}$ changes (assimilation case-the a priori) at the TES (Fig. 14), OMI (Fig. 15a-d) sampling locations and at THD (Fig. 15e-f) for Cases AS, $\mathrm{AT}, \mathrm{AO}$, and $\mathrm{AD}$. These compare the consistency in the information provided by these observations.

At the TES sampling locations (Fig. 14a,c,e,g, raw data: before applying the observation operator), assimilations of all types of observations result in modification of $\mathrm{O}_{3}$ in the similar location in the mid troposphere (i.e., $\sim 500-700 \mathrm{hPa}$ ), mostly south of $44^{\circ} \mathrm{N}$, where the highest biases in the a priori occur. Cases AT, AS and AD result in similar spatial distributions of the $\mathrm{O}_{3}$ changes, and Case AT shows the biggest changes ( -20 to $>40 \mathrm{ppb}$ ), while Case AO results in approximately the opposite changes. After applying the TES observation operator (Fig. 14b,d,f,h), the changes between all four cases and the a priori were smoothed (showing decreased magnitudes and extended affected regions as high as to the upper troposphere).

At the OMI sampling locations, assimilating different types of observations all modify the $\mathrm{O}_{3}$ raw data (Fig. 15a-d black dots) at most altitudes, and Case $\mathrm{AO}$ shows the biggest changes ( -20 to $50 \mathrm{ppb}$ ), followed by Case AS ( -10 to $40 \mathrm{ppb}$ ). Cases AS, AT and AD result in overall negative changes while Case AO caused positive changes. Together with Fig. 14, these indicate a possible high positive bias in OMI measurements. After applying the OMI observation operator (Fig. 15a-d red dots), again the changes between all cases and a priori were smoothed.

Figure 15e-f compare the $\mathrm{O}_{3}$ vertical profiles at THD from sonde, the a priori and the assimilation cases. The a priori overestimates $\mathrm{O}_{3}$ at $<2 \mathrm{~km}$ and $>10 \mathrm{~km}$, and underestimates $\mathrm{O}_{3}$ at $2-3 \mathrm{~km}$. Case AD generates best results, especially the variability at $\sim 2-3 \mathrm{~km}$ and $>10 \mathrm{~km}$ (Fig. 15e). Assimilating surface measurements modifies $\mathrm{O}_{3}$ structure at $<2 \mathrm{~km}$, and $\mathrm{O}_{3}$ increases at $\sim 2-4 \mathrm{~km}$ by up to $15 \mathrm{ppb}$, but fails to capture the sharp variability. The changes made by assimilating TES and OMI measurements at THD are much smaller ( $<1 \mathrm{ppb}$ ), mainly occurring at $\sim 2-4 \mathrm{~km}$ and $6-10 \mathrm{~km}$ for TES and OMI, respectively.

\section{Assimilation impacts on the estimated contributions from TBG and local emissions}

The 4D-Var approach can provide further insights into the contributions from BCs and local emissions. The assimilation of surface observations (Case AS) changed $\mathrm{O}_{3}$ along the TES orbit by $+(1-6) \mathrm{ppb}(\sim 3 \mathrm{ppb})$ at $40-42^{\circ} \mathrm{N}$ (Fig. 14a). This indicates that the inflow over the eastern Pacific for this specific case was underestimated by $\sim 3 \mathrm{ppb}$. If we assume the addition of changes in offshore FT to surface $\mathrm{O}_{3}$ is close to linear everywhere, then this implies that the TBG contribution to surface $\mathrm{O}_{3}$ after assimilation rises by $\sim 3 \mathrm{ppb}$. The 
Table 6. Changes of daytime-mean surface $\mathrm{O}_{3}$ errors between different cases, where error $=\mid$ modeled-observed $\mid$.

\begin{tabular}{lrrrrrr}
\hline Cases & Min. & 1st Qu. & Median & Mean & 3rd Qu. & Max. \\
\hline AS-a priori & -16.59 & -9.15 & -4.02 & -5.01 & -0.21 & 4.38 \\
AT-a priori & $-6.60 \mathrm{E}-02$ & $-7.00 \mathrm{E}-03$ & $-2.00 \mathrm{E}-03$ & $-4.00 \mathrm{E}-03$ & $1.00 \mathrm{E}-03$ & $1.50 \mathrm{E}-02$ \\
AO-a priori & $-8.10 \mathrm{E}-02$ & $-2.00 \mathrm{E}-03$ & $\sim 0$ & $8.00 \mathrm{E}-03$ & $2.40 \mathrm{E}-02$ & $1.10 \mathrm{E}-01$ \\
AD-a priori & $-1.84 \mathrm{E}-01$ & $-1.30 \mathrm{E}-02$ & $-3.00 \mathrm{E}-03$ & $-1.30 \mathrm{E}-02$ & $\sim 0$ & $1.60 \mathrm{E}-02$ \\
AST-AS & -1.15 & -0.10 & 0.13 & 0.18 & 0.50 & 1.01 \\
ASO-AS & -0.80 & -0.15 & 0.23 & 0.22 & 0.50 & 1.30 \\
ASD-AS & -0.71 & -0.12 & 0.37 & 0.35 & 0.70 & 1.54 \\
\hline
\end{tabular}
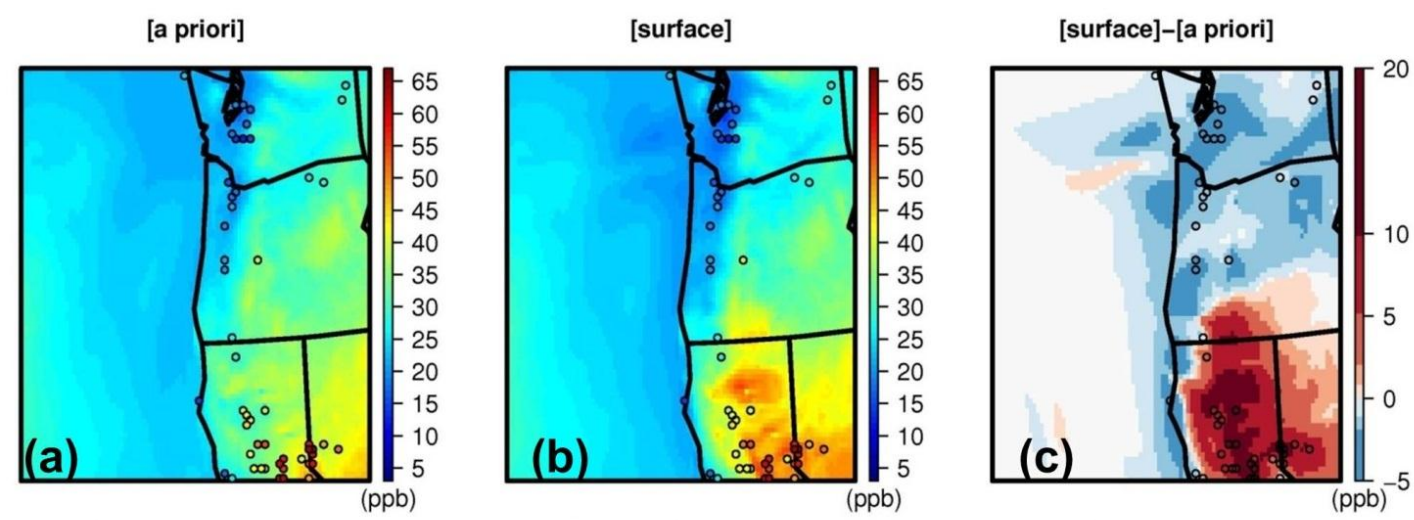

[TES only]-[a priori]

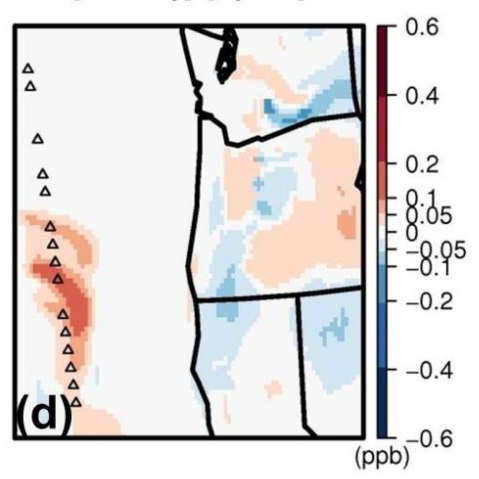

[OMI only]-[a priori]

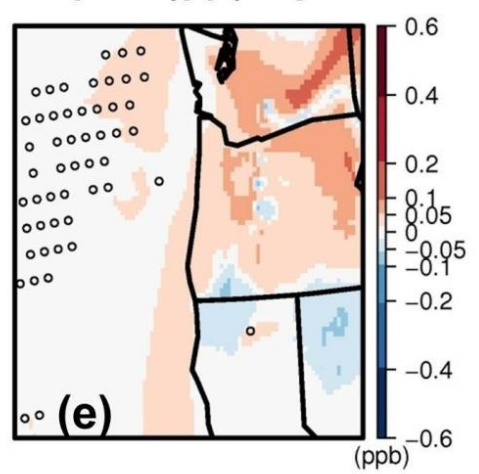

[sonde only]-[a priori]

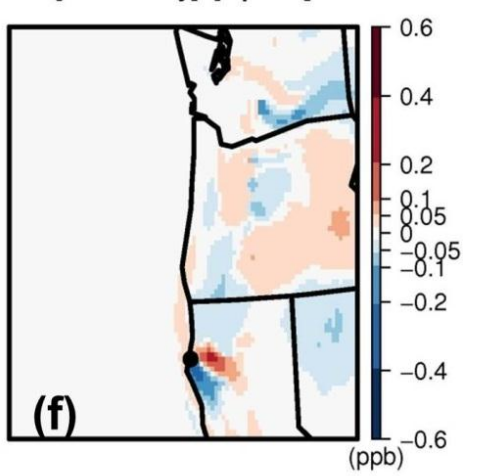

[TES+surface]-[surface]
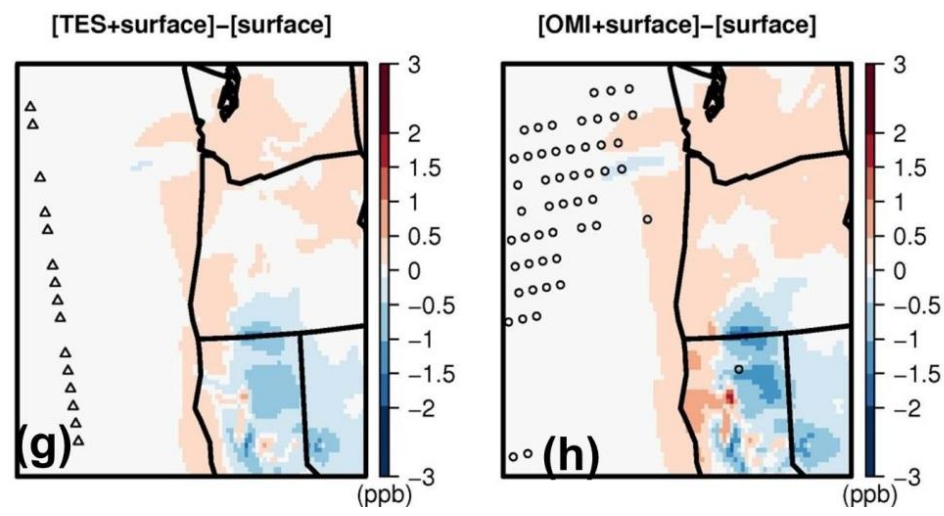

[sonde+surface]-[surface]

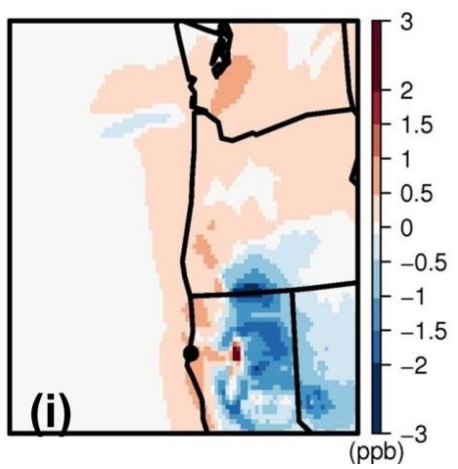

Fig. 13. Impacts of DA at the surface. Daytime-mean surface $\mathrm{O}_{3}$ from (a) STEM a priori; and (b) Case AS. The site measurements were overlaid (only those sites that had all daytime measurements are shown in the plots). (c) Differences of (b)-(a). Daytime-mean surface $\mathrm{O}_{3}$ differences: (d) Case AT-STEM a priori; (e) Case AO-STEM a priori; (f) Case AD-STEM a priori. Daytime-mean surface $\mathrm{O}_{3}$ differences: (g) Case AST-Case AS; (h) Case ASO-Case AS; (i) Case ASD-Case AS. See text and Table 3 for definition of the various cases. 

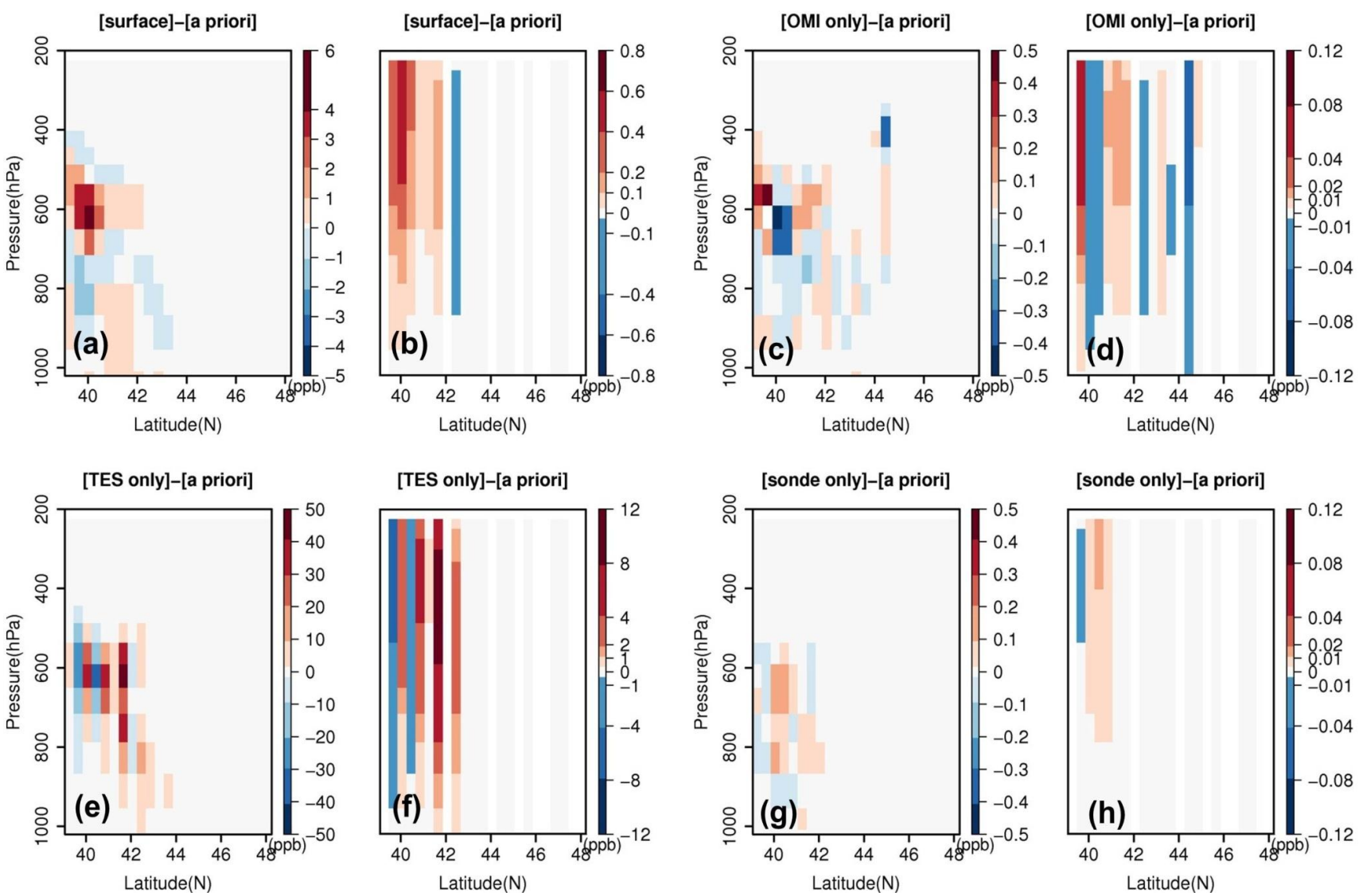

Fig. 14. Impacts of DA in the vertical. $\mathrm{O}_{3}$ differences at the selected TES sampling locations: (a-b) Case AS-STEM a priori; (c-d) Case AO-STEM a priori; (e-f) Case AT-STEM a priori; (g-h) Case AD-STEM a priori. (a,c,e,g) compare the raw data in TES pressure grids and (b,d,f,h) compare the results after applying the TES observation operator.

gross changes in surface $\mathrm{O}_{3}$ after assimilation were $+(5-$ $15) \mathrm{ppb}(\sim+10 \mathrm{ppb})$ over northern $\mathrm{CA}$ and $-(1-3) \mathrm{ppb}(\sim-$ $2 \mathrm{ppb}$ ) over Region 10. If the rest of errors are assumed to be solely due to local emissions, then the local emissions would need to be adjusted in a manner that would change the surface $\mathrm{O}_{3}$ over Regions 9 and 10 by $\sim 7 \mathrm{ppb}$ and $\sim-5 \mathrm{ppb}$, respectively.

Additional DA methods to improve the estimates of TBG/extra-regional contributions in future include: (1) To improve the chemical fields in global models that are used as regional model BCs; and (2) To improve the emissions (e.g., $\mathrm{NO}_{\mathrm{x}}$ ) in extra-regions, and then use the improved emissions to calculate the contributions from extra regions through sensitivity analysis or tagging methods.

\section{Estimation of the uncertainties in satellite retrievals}

We determine the upper limits of satellite retrievals from the discrepancies between retrievals and the assimilated fields of Case AS (Fig. 15g). This estimate is based on the assumption that assimilated fields in this case provide the "best" $\mathrm{O}_{3}$ distributions in the lower/mid-troposphere over the domain.
TES shows $5-20 \%$ positive biases at $500-900 \mathrm{hPa}$ (the region that surface layer $\mathrm{O}_{3}$ is sensitive to at the overpass time), and OMI has a 5-10\% higher bias than TES. This estimation is consistent with conclusions in previous validation studies, but this method needs to be further tested for extended regions and periods.

Discrepancies between THD sonde and assimilated $\mathrm{O}_{3}$ at THD in Case AS are varied, due to much higher vertical resolution and accuracy of the sonde. Case AS is not able to correct the detailed vertical variability due to the coarser model vertical structure.

\section{Conclusions and suggestions on future work}

In summer 2008, the model-estimated TBG contributions to MDA8 were $\sim 30-35 \mathrm{ppb}$ for EPA Regions 9 and 10 . The modeled TBG contributions to W126 were $\sim 10-17 \mathrm{ppm}-\mathrm{h}$ for Region 9 and $\sim 3-4 \mathrm{ppm}-\mathrm{h}$ for Region 10 . The strongest TBG impacts on W126 occurred over the grass/shrubcovered regions. Among the TBG pollutants, $\mathrm{O}_{3}$ is the major contributor to surface $\mathrm{O}_{3}$, while PAN is the most important 
(a) [surface]-[a priori]

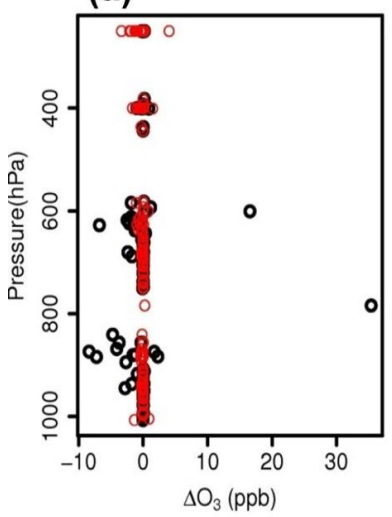

(b) [OMI only]-[a priori]

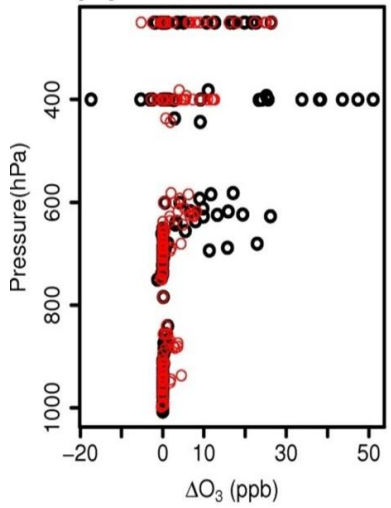

(c) $)^{\text {[TES only]-[a priori] }}$

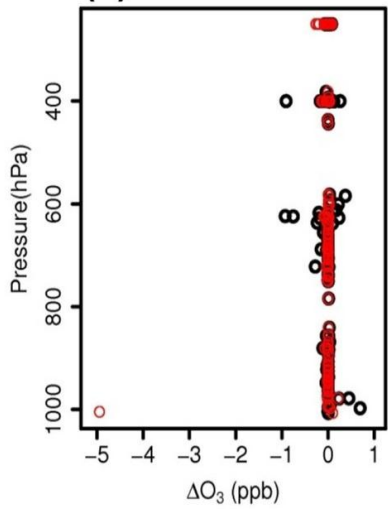

(d) [sonde only]-[a priori]

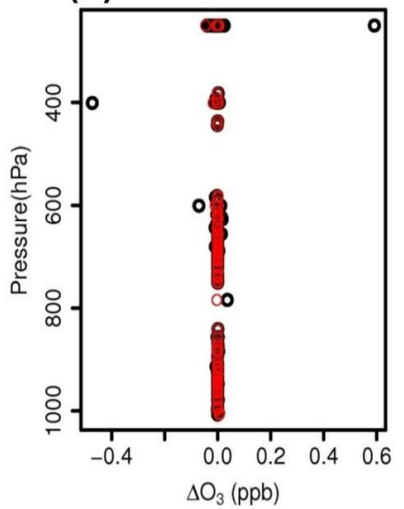

(e) ${ }^{\mathrm{THD} \mathrm{O}_{3} \text { sonde, July } 5}$

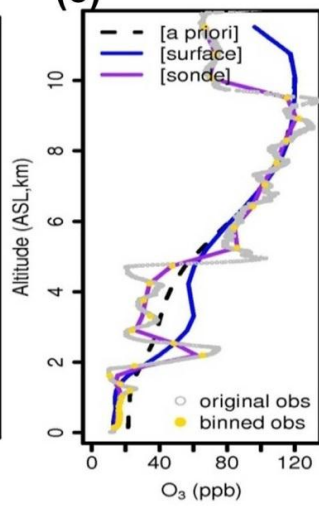

(f) [satellite only]-[a priori]

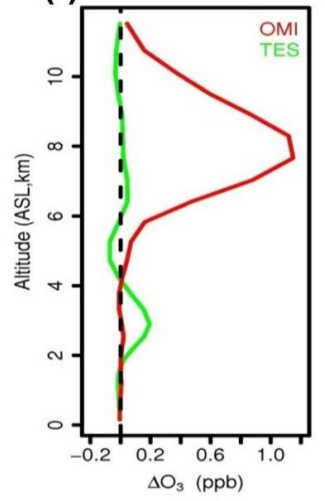

(g)

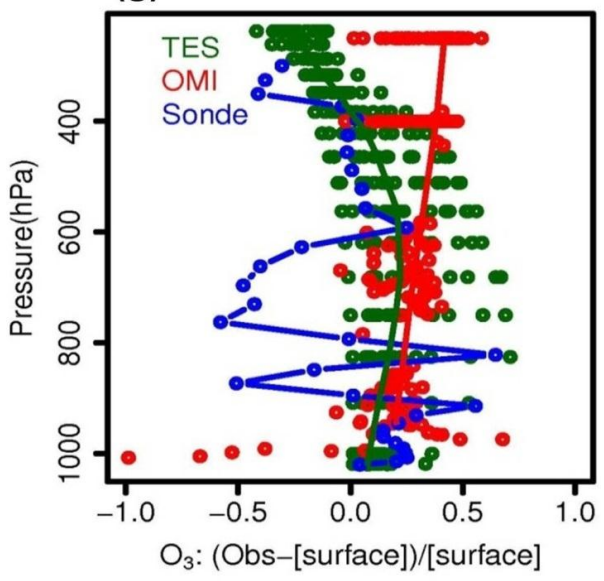

Fig. 15. Impacts of DA in the vertical. $\mathrm{O}_{3}$ differences at selected OMI sampling locations: (a) Case AS-STEM a priori; (b) Case AO-STEM a priori; (c) Case AT-STEM a priori; (d) Case AD-STEM a priori. In (a-d), black dots compare the raw data in OMI pressure grids and red dots compare the results after applying the OMI observation operator. (e) $\mathrm{O}_{3}$ vertical profiles at THD on 5 July from sondes, STEM a priori, Cases AS and AD; (f) $\mathrm{O}_{3}$ differences between Cases AT and AO and STEM a priori; (g) Comparison between measurements and the assimilated $\mathrm{O}_{3}$ in Case $\mathrm{AS}$, at corresponding measurement locations. This is used to quantify the upper limits of satellite uncertainties, with the assumption that Case AS provides the "best" $\mathrm{O}_{3}$ distributions over the model domain.

$\mathrm{O}_{3}$ precursor species. W126 showed larger responses than MDA8 to TBG perturbations and stronger non-linearity to the magnitude of perturbations. The TBG impacts on both metrics overall negatively correlate to model vertical resolution and positively correlate to the horizontal resolution.

Ozone at MBO and THD was significantly affected by TBG pollutants and occasionally affected by local emissions, while $\mathrm{SC} \mathrm{O}_{3}$ was strongly affected by local emissions. The importance of airmasses over the eastern Pacific being transported inland and entrained into the PBL to impact surface $\mathrm{O}_{3}$ was demonstrated by the IP metric and adjoint sensitivities. The IP metric showed that the probabilities of airmasses originating from MBO $(2.7 \mathrm{~km})$ and THD $(2.5 \mathrm{~km})$ impacting downwind surface air quality reached daily maxima of $66 \%$ and $34 \%$ at $\sim 03: 00$ p.m. PDT, respectively, and the IP metric for SC $(1.5 \mathrm{~km})$ stayed above $50 \%$ during 09:00 a.m.04:00 p.m. PDT. Receptor-based adjoint sensitivity analysis further highlighted the transport/subsidence processes that link airmasses aloft with the surface, showing that $\mathrm{O}_{3}$ at $1-$ $4 \mathrm{~km}$ had the biggest impact on inland surface $\mathrm{O}_{3} 1-2$ days later.

A case study demonstrated that assimilating surface in-situ observations was successful in constraining modeled $\mathrm{O}_{3}$ spatial distributions in regions where these measurements are dense. Assimilation of the surface in-situ measurements significantly reduced ( $\sim 5 \mathrm{ppb}$ on average and up to $\sim 17 \mathrm{ppb}$ ) the modeled surface $\mathrm{O}_{3}$ errors during a LRT episode, and increased the estimated TBG by $\sim 3 \mathrm{ppb}$. However, in this case assimilation of existing $\mathrm{O}_{3}$ vertical profiles from satellites and sondes did not efficiently improve the modeled $\mathrm{O}_{3}$ except near the sampling locations.

Suggestions on future work include:

1. A quantitative source attribution requires the use of global models, but the improvement in model predictability and the investigation of the export/import budgets can benefit from nesting with high resolution 
regional models at the sources/receptors, as well as a better understanding of the distributions of $\mathrm{O}_{3}$ and its precursors at the regional model boundary. Data assimilation in both global (used as regional model BCs) and regional models is useful for improving the modelestimated TBG contributions and total $\mathrm{O}_{3}$ concentrations.

2. Due to the non-linear function used in calculating W126 and the resulting differences from MDA8, continuous efforts on analyzing various contributors to W126 by multiple methods (e.g., tagging, perturbations and adjoint sensitivity analysis) and additional observations over different vegetation types would be helpful for determining the secondary standard and assessing $\mathrm{O}_{3}$ impacts on ecosystems.

3. To better understand model-based transport/subsidence processes and improve DA efficiency, and to further explore the relationship between meteorological conditions and air pollution, it is important to make denser and routine measurements of key meteorological variables such as PBLH - The WRF-modeled PBLH over complex terrain can vary significantly when different PBL schemes and WRF versions were applied (e.g., Fig. S5 and Saide et al., 2011), but current PBLH measurements are limited for evaluation. Efforts should also focus on measuring additional $\mathrm{O}_{3}$ vertical profiles (e.g., extended ozonesonde network and measurements on commercial airlines) and exploring the needs (e.g., appropriate resolution, retrieval quality) for future geostationary missions (such as TEMPO and GEO-CAPE over the US).

\section{Supplementary material related to this article is available online at: http://www.atmos-chem-phys.net/13/ 359/2013/acp-13-359-2013-supplement.pdf.}

Acknowledgements. This work was supported by NASA awards: NNX08AH56G, NNX08AL06G and NNX11AI52G. The authors would like to thank the ARCTAS science team, the people who made the AQS, CASTNET, OMI, TES, MODIS and MISR measurements, and CGRER members who contributed to building the STEM forecast modeling system for ARCTAS. We thank two anonymous referees and Thomas Peters, Charles Stanier and Vicki Grassian (U Iowa) for commenting on previous versions of the paper. We thank Daven Henze (CU-Boulder) for suggesting the W126 calculations. The revision was performed at Jet Propulsion Laboratory, California Institute of Technology, under a contract with NASA. We thank CGRER (U Iowa) and Pleiades (NASA Ames) computational resources and the technical support especially from Jeremie Moen and Johnny Chang. The views, opinions, and findings contained in this paper are those of the authors and should not be construed as an official NOAA or U.S. Government position, policy, or decision.
Edited by: T. Butler

\section{References}

Adhikary, B., Carmichael, G. R., Kulkarni, S., Wei, C., Tang, Y., D’Allura, A., Mena-Carrasco, M., Streets, D. G., Zhang, Q., Pierce, R. B., Al-Saadi, J. A., Emmons, L. K., Pfister, G. G., Avery, M. A., Barrick, J. D., Blake, D. R., Brune, W. H., Cohen, R. C., Dibb, J. E., Fried, A., Heikes, B. G., Huey, L. G., O’Sullivan, D. W., Sachse, G. W., Shetter, R. E., Singh, H. B., Campos, T. L., Cantrell, C. A., Flocke, F. M., Dunlea, E. J., Jimenez, J. L., Weinheimer, A. J., Crounse, J. D., Wennberg, P. O., Schauer, J. J., Stone, E. A., Jaffe, D. A., and Reidmiller, D. R.: A regional scale modeling analysis of aerosol and trace gas distributions over the eastern Pacific during the INTEX-B field campaign, Atmos. Chem. Phys., 10, 2091-2115, doi:10.5194/acp-10-20912010, 2010.

Alvarado, M. J., Logan, J. A., Mao, J., Apel, E., Riemer, D., Blake, D., Cohen, R. C., Min, K.-E., Perring, A. E., Browne, E. C., Wooldridge, P. J., Diskin, G. S., Sachse, G. W., Fuelberg, H., Sessions, W. R., Harrigan, D. L., Huey, G., Liao, J., Case-Hanks, A., Jimenez, J. L., Cubison, M. J., Vay, S. A., Weinheimer, A. J., Knapp, D. J., Montzka, D. D., Flocke, F. M., Pollack, I. B., Wennberg, P. O., Kurten, A., Crounse, J., Clair, J. M. St., Wisthaler, A., Mikoviny, T., Yantosca, R. M., Carouge, C. C., and Le Sager, P.: Nitrogen oxides and PAN in plumes from boreal fires during ARCTAS-B and their impact on ozone: an integrated analysis of aircraft and satellite observations, Atmos. Chem. Phys., 10, 9739-9760, doi:10.5194/acp-10-9739-2010, 2010.

Ambrose, J., Reidmiller, D., and Jaffe, D.: Causes of high $\mathrm{O}_{3}$ in the lower free troposphere over the Pacific Northwest as seen at the Mt. Bachelor Observatory, Atmos. Environ., 45, 5302-5315, doi:10.1016/j.atmosenv.2011.06.056, 2011.

Beer, R.: TES on the Aura Mission: Scientific Objectives, Measurements, and Analysis Overview, IEEE Geosci. Remote S., 44, 1102-1105, doi:10.1109/TGRS.2005.863716, 2006.

Bertschi, I. B., Jaffe, D. A., Jaegle, L., Price, H. U., and Dennison, J. B.: PHOBEA/ITCT 2002 airborne observations of trans-Pacific transport of ozone, CO, VOCs and aerosols to the northeast Pacific: Impacts of Asian anthropogenic and Siberian Boreal fire emissions, J. Geophys. Res., 109, D23S12, doi:10.1029/2003JD004328, 2004.

Bouttier, F. and Courtier, P.: Data assimilation concepts and methods, http://www.ecmwf.int/newsevents/training/rcourse_notes/ DATA_ASSIMILATION/ASSIM_CONCEPTS/Assim_concepts. html, 1999.

Bowman, K. W., Rodgers, C. D., Kulawik, S. S., Worden, J., Sarkissian, E., Osterman, G., Steck, T., Ming Lou, Eldering, A., Shephard, M., Worden, H., Lampel, M., Clough, S., Brown, P., Rinsland, C., Gunson, M., and Beer, R., Tropospheric Emission Spectrometer: Retrieval method and error analysis, IEEE Trans Geosci Rem Sens., 4, 1297-1307, doi:10.1109/TGRS.2006.871234, 2006.

Boxe, C. S., Worden, J. R., Bowman, K. W., Kulawik, S. S., Neu, J. L., Ford, W. C., Osterman, G. B., Herman, R. L., Eldering, A., Tarasick, D. W., Thompson, A. M., Doughty, D. C., Hoffmann, M. R., and Oltmans, S. J.: Validation of northern latitude Tropospheric Emission Spectrometer stare ozone profiles with ARC-IONS sondes during ARCTAS: sensitivity, bias and error 
analysis, Atmos. Chem. Phys., 10, 9901-9914, doi:10.5194/acp10-9901-2010, 2010.

Boylan, J. W. and Russell, A. G.: PM and light extinction model performance metrics, goals, and criteria for threedimensional air quality models, Atmos. Environ., 40, 49464959, doi:10.1016/j.atmosenv.2005.09.087, 2006.

Carmichael, G. R., Tang, Y., Kurata, G., Uno, I., Streets, D. G., Thongboonchoo, N., Woo, J. H., Guttikunda, S., White, A., Wang, T., Blake, D. R., Atlas, E., Fried, A., Potter, B., Avery, M. A., Sachse, G. W., Sandholm, S. T., Kondo, Y., Talbot, R. W., Bandy, A., Thorton, D., and Clarke, A. D.: Evaluating regional emission estimates using the TRACE-P observations, J. Geophys. Res., 108, 8810, doi:10.1029/2002JD003116, 2003 a.

Carmichael, G. R., Tang, Y., Kurata, G., Uno, I., Streets, D., Woo, J. H., Huang, H., Yienger, J., Lefer, B., Shetter, R., Blake, D., Atlas, E., Fried, A., Apel, E., Eisele, F., Cantrell, C., Avery, M., Barrick, J., Sachse, G., Brune, W., Sandholm, S., Kondo, Y., Singh, H., Talbot, R., Bandy, A., Thorton, D., Clarke, A., and Heikes, B.: Regional-scale chemical transport modeling in support of the analysis of observations obtained during the TRACE-P experiment, J. Geophys. Res., 108, 8823, doi:10.1029/2002JD003117, 2003b.

Carmichael, G. R., Sandu, A., Chai, T., Daescu, D. N., Constantinescu, E. M., and Tang, Y.: Predicting air quality: Improvements through advanced methods to integrate models and measurements, J. Comput. Phys., 227, 3540-3571, doi:10.1016/j.jcp.2007.02.024, 2008.

Carter, W. P. L.: Documentation of the SAPRC-99 chemical mechanism for VOC Reactivity Assessment, final report to California Air Resources Board, Contract No. 92-329 and 95-308, 2000.

Chai, T., Carmichael, G. R., Sandu, A., Tang, Y., and Daescu, D.N.: Chemical data assimilation of Transport and Chemical Evolution over the Pacific (TRACE-P) aircraft measurements, J. Geophys. Res., 111, D02301, doi:10.1029/2005JD005883, 2006.

Chai, T., Carmichael, G. R., Tang, Y., Sandu, A., Hardesty, M., Pilewskie, P., Whitlow, S., Browell, E. V., Avery, M. A., Nedelec, P., Merrill, J. T., Thompson, A. M., and Williams, E.: Four Dimensional Data Assimilation Experiments with ICARTT (International Consortium for Atmospheric Research on Transport and Transformation) Ozone Measurements, J. Geophys. Res., 112, D12S15, doi:10.1029/2006JD007763, 2007.

Chai, T., Carmichael, G. R., Tang, Y., Sandu, A., Heckel, A., Richter, A., and Burrows, J. P.: Regional $\mathrm{NO}_{\mathrm{x}}$ emission inversion through a four-dimensional variational approach using SCIAMACHY tropospheric $\mathrm{NO}_{2}$ column observations, Atmos. Environ., 43, 5046-5055, 2009.

Committee on Earth Observation Satellites (CEOS): A Geostationary Satellite Constellation for Observing Global Air Quality: An International Path Forward, http://www.ceos.org/images/ ACC/AC_Geo_Position_Paper_v4.pdf, 2011.

Cooper, O. R., Trainer, M., Thompson, A.M., Oltmans, S. J., Tarasick, D.W., Witte, J.C., Stohl, A., Eckhardt, S., Lelieveld, J., Newchurch, M.J., Johnson, B. J., Portmann, R. W., Kalnajs, L., Dubey, M.K., Leblanc, T., McDermid, I.S., Forbes, G., Wolfe, D. E., Carey-Smith, T., Morris, G.A., Lefer, B., Rappenglück, B., Joseph, E., Schmidlin, F., Meagher, J. F., Fehsenfeld, F. C., Keating, T.J., Van Curen, R.A., and Minschwaner, K.: Evidence for a recurring eastern North America upper tropospheric ozone maximum during summer, J.
Geophys. Res., 112, D23304, doi:10.1029/2007JD008710, 2007. Cooper, O. R., Parrish, D. D., Stohl, A., Trainer, M., Nedelec, P., Thouret, V., Cammas, J. P., Oltmans, S. J., Johnson, B. J., Tarasick, D., Leblanc, T., McDermid, I. S., Jaffe, D., Gao, R., Stith, J., Ryerson, T., Aikin, K., and Campos, T., Weinheimer, A., and Avery, M. A.: Increasing springtime ozone mixing ratios in the free troposphere over western North America, Nature, 463, 344 348, doi:10.1038/nature08708, 2010

Cooper, O. R., Oltmans, S. J., Johnson, B. J., Brioude, J., Angevine, W., Trainer, M., Parrish, D. D., Ryerson, T. R., Pollack, I., Cullis, P. D., Ives, M. A., Tarasick, D. W., Al-Saadi, J., and Stajner, I.: Measurement of western U.S. baseline ozone from the surface to the tropopause and assessment of downwind impact regions, J. Geophys. Res., 116, D00V03, doi:10.1029/2011JD016095, 2011.

Cooper, O. R., Gao, R. S., Tarasick, D. W., Leblanc, T., and Sweeney, C.: Long-term ozone trends at rural ozone monitoring sites across the United States, 1990-2010, J. Geophys. Res., 117, D22307, doi:10.1029/2012JD018261, 2012.

Davies, D. K., Ilavajhala, S., Wong, M. M., and Justice, C. O.: Fire Information for Resource Management System: Archiving and Distributing MODIS Active Fire Data, IEEE Trans Geosci Rem Sens., 47, 72-79, 2009.

Fischer, E. V., Jaffe, D. A., Reidmiller, D. R., and Jaegle, L.: Meteorological controls on observed peroxyacetyl nitrate at Mount Bachelor during the spring of 2008, J. Geophys. Res., 115, D03302, doi:10.1029/2009JD012776, 2010.

Fischer, E. V., Jaffe, D. A., and Weatherhead, E. C.: Free tropospheric peroxyacetyl nitrate (PAN) and ozone at Mount Bachelor: potential causes of variability and timescale for trend detection, Atmos. Chem. Phys., 11, 5641-5654, doi:10.5194/acp-115641-2011, 2011.

Fiore, A. M., Dentener, F. J., Wild, O., Cuvelier, C., Schultz, M. G., Hess, P., Textor, C., Schulz, M., Doherty, R. M., Horowitz, L.W., MacKenzie, I. A., Sanderson, M. G., Shindell, D. T., Stevenson, D. S., Szopa, S., Van Dingenen, R., Zeng, G., Atherton, C., Bergmann, D., Bey, I., Carmichael, G., Collins, W. J., Duncan, B. N., Faluvegi, G., Folberth, G., Gauss, M., Gong, S., Hauglustaine, D., Holloway, T., Isaksen, I. S. A., Jacob, D. J., Jonson, J. E., Kaminski, J. W., Keating, T. J., Lupu, A., Marmer, E., Montanaro, V., Park, R. J., Pitari, G., Pringle, K. J., Pyle, J. A., Schroeder, S., Vivanco, M. G., Wind, P., Wojcik, G., Wu, S., and Zuber, A.: Multimodel estimates of intercontinental source receptor relationships for ozone pollution, J. Geophys. Res., 114, D04301, doi:10.1029/2008JD010816, 2009.

Freitas, S. R., Longo, K. M., Alonso, M. F., Pirre, M., Marecal, V., Grell, G., Stockler, R., Mello, R. F., and Sánchez Gácita, M.: PREP-CHEM-SRC - 1.0: a preprocessor of trace gas and aerosol emission fields for regional and global atmospheric chemistry models, Geosci. Model Dev., 4, 419-433, doi:10.5194/gmd-4419-2011, 2011.

Fu, D., Worden, J. R., Liu, X., Kulawik, S. S., Bowman, K. W., and Natraj, V.: Characterization of ozone profiles derived from Aura TES and OMI Radiances, Atmos. Chem. Phys. Discuss., 12, 27589-27636, doi:10.5194/acpd-12-27589-2012, 2012.

Fuelberg, H. E., Harrigan, D. L., and Sessions, W.: A meteorological overview of the ARCTAS 2008 mission, Atmos. Chem. Phys., 10, 817-842, doi:10.5194/acp-10-817-2010, 2010. 
Giglio, L., Descloitres, J., Justice, C. O., and Kaufman, Y. J.: An Enhanced Contextual Fire Detection Algorithm for MODIS, Remote Sens. Environ., 87, 273-282, 2003.

Hakami, A., Henze, D. K., Seinfeld, J. H., Chai, T., Tang, Y., Carmichael, G. R., and Sandu, A.: Adjoint Inverse Modeling of Black Carbon During ACE-Asia, J. Geophys. Res., 110, D14301, doi:10.1029/2004JD005671, 2005.

Hakami, A., Seinfeld, J. H., Chai, T. F., Tang, Y. H., Carmichael, G. R., and Sandu, A: Adjoint sensitivity analysis of ozone nonattainment over the continental United States, Environ. Sci. Technol., 40, 3855-3864, doi:10.1021/es052135g, 2006.

Henze, D. K., Seinfeld, J. H., and Shindell, D. T.: Inverse modeling and mapping US air quality influences of inorganic PM2.5 precursor emissions using the adjoint of GEOS-Chem, Atmos. Chem. Phys., 9, 5877-5903, doi:10.5194/acp-9-5877-2009, 2009.

Huang, M., Carmichael, G. R., Adhikary, B., Spak, S. N., Kulkarni, S., Cheng, Y. F., Wei, C., Tang, Y., Parrish, D. D., Oltmans, S. J., D’Allura, A., Kaduwela, A., Cai, C., Weinheimer, A. J., Wong, M., Pierce, R. B., Al-Saadi, J. A., Streets, D. G., and Zhang, Q.: Impacts of transported background ozone on California air quality during the ARCTAS-CARB period - a multi-scale modeling study, Atmos. Chem. Phys., 10, 6947-6968, doi:10.5194/acp-106947-2010, 2010a.

Huang, M., Carmichael, G. R., Spak, S., Adhikary, B., Kulkarni, S., Cheng, Y., Wei, C., Tang, Y., Parrish, D. D., Oltmans, S. J., D’Allura, A., Wennberg, P. O., Huey, L. G., Dibb, J. E., Jimenez, J. L., Weinheimer, A. J., Kaduwela, A., Cai, C., Wong, M., Pierce, R., Al-Saadi, J. A., Streets, D. G., and Zhang, Q.: Impacts of long-range transport and local emissions on California near-surface ozone and sulfur oxides during the ARCTAS period-A multi-scale modeling study, AGU fall meeting, San Francisco, CA, December, 2010b.

Huang, M., Carmichael, G. R., Spak, S. N., Adhikary, B., Kulkarni, S., Cheng, Y., Wei, C., Tang, Y., D’Allura, A., Wennberg, P. O., Huey, G. L., Dibb, J. E., Jimenez, J.L., Cubison, M. J., Weinheimer, A. J., Kaduwela, A., Cai, C., Wong, M., Bradley Pierce, R., Al-Saadi, J. A., Streets, D. G., and Zhang, Q.: Multi-scale modeling study of the source contributions to nearsurface ozone and sulfur oxides levels over California during the ARCTAS-CARB period, Atmos. Chem. Phys., 11, 3173-3194, doi:10.5194/acp-11-3173-2011, 2011.

Huang, M., Carmichael, G. R., Kulkarni, S., Streets, D. G., Lu, Z., Zhang, Q., Pierce, R. B., Kondo, Y., Jimenez, J. L., Cubison, M. J., Anderson, B., and Wisthaler, A.: Sectoral and geographical contributions to summertime continental United States (CONUS) black carbon spatial distributions, Atmos. Environ., 51, 165-174, doi:10.1016/j.atmosenv.2012.01.021, 2012.

Jacob, D. J., Crawford, J. H., Maring, H., Clarke, A. D., Dibb, J. E., Emmons, L. K., Ferrare, R. A., Hostetler, C. A., Russell, P. B., Singh, H. B., Thompson, A. M., Shaw, G. E., McCauley, E., Pederson, J. R., and Fisher, J. A.: The Arctic Research of the Composition of the Troposphere from Aircraft and Satellites (ARCTAS) mission: design, execution, and first results, Atmos. Chem. Phys., 10, 5191-5212, doi:10.5194/acp-10-5191-2010, 2010.

Jaffe, D., Bertschi, I., Jaegle, L., Novelli, P., Reid, J. S., Tanimoto, H., Vingarzan, R.., and Westphal, D. L.: Long-range transport of Siberian biomass burning emissions and impact on surface ozone in western North America, Geophys. Res. Lett., 31, L16106,
doi:10.1029/2004GL020093, 2004.

Kopacz, M., Mauzerall, D.L., Wang, J., Leibensperger, E. M., Henze, D. K., and Singh, K.: Origin and radiative forcing of black carbon transported to the Himalayas and Tibetan Plateau, Atmos. Chem. Phys., 11, 2837-2852, doi:10.5194/acp-11-28372011, 2011.

Kroon, M., de Haan, J. F., Veefkind, J. P., Froidevaux, L., Wang, R., Kivi, R., and Hakkarainen, J. J.: Validation of operational ozone profiles from the Ozone Monitoring Instrument, J. Geophys. Res., 116, D18305, doi:10.1029/2010JD015100, 2011.

Langford, A. O., Brioude, J., Cooper, O.R., Senff, C.J., Alvarez II, R.J., Hardesty, R.M., Johnson, B.J., and Oltmans, S.J.: Stratospheric influence on surface ozone in the Los Angeles area during late spring and early summer of 2010, J. Geophys. Res., 117, D00V06, doi:10.1029/2011JD016766, 2011.

Lathière, J., Hauglustaine, D. A., Friend, A. D., De NobletDucoudré, N., Viovy, N., and Folberth, G. A.: Impact of climate variability and land use changes on global biogenic volatile organic compound emissions, Atmos. Chem. Phys., 6, 2129-2146, doi:10.5194/acp-6-2129-2006, 2006.

Lin, M., Holloway, T., Carmichael, G. R., and Fiore, A. M.: Quantifying pollution inflow and outflow over East Asia in spring with regional and global models, Atmos. Chem. Phys., 10, 42214239, doi:10.5194/acp-10-4221-2010, 2010.

Lin, M., A. M. Fiore, L. W. Horowitz, O. R. Cooper, V. Naik, J. Holloway, B. J. Johnson, A. Middlebrook, S. J. Oltmans, I. B. Pollack, T. B. Ryerson, J. X. Warner, C. Wiedinmyer, J. Wilson, B. Wyman: Transport of Asian ozone pollution into surface air over the western United States in spring, J. Geophys. Res., 117, D00V07, doi:10.1029/2011JD016961, 2012a.

Lin, M., Fiore, A., Cooper, O. R. R., Horowitz, L. W., Langford, A. O. O., Levy II, H., Johnson, B. J., Naik, V., Oltmans, S. J., and Senff, C. J.: Springtime high surface ozone events over the western United States: Quantifying the role of stratospheric intrusions, J. Geophys. Res., 117, D00V22, doi:10.1029/2012JD018151, 2012b.

Liu, G., Tarasick, D. W., Fioletov, V. E., Sioris, C. E., and Rochon, Y. J.: Ozone correlation lengths and measurement uncertainties from analysis of historical ozonesonde data in North America and Europe, J. Geophys. Res., 114, D04112, doi:10.1029/2008JD010576, 2009.

Madronich, S., Flocke, S., Zeng, J., Petropavlovskikh, I., and LeeTaylor, J.: The Tropospheric Ultra-violet Visible (TUV) model Manual, http://www.acd.ucar.edu/, 2002.

McKeen, S., Grell, G., Peckham, S., Wilczak, J., Djalalova, I., Hsie, E.-Y., Frost, G., Peischl, J., Schwarz, J., Spackman, R., Holloway, J., de Gouw, J., Warneke, C., Gong, W., Bouchet, V., Gaudreault, S., Racine, J., McHenry, J., McQueen, J., Lee, P., Tang, Y., Carmichael, G. R., and Mathur, R.: An evaluation of real-time air quality forecasts and their urban emissions over eastern Texas during the summer of 2006 Second Texas Air Quality Study field study, J. Geophys. Res., 114, D00F11, doi:10.1029/2008JD011697, 2009.

Mena-Carrasco, M., Tang, Y., Carmichael, G.R., Chai, T., Thongbongchoo, N., Campbell, J.E., Kulkarni, S., Horowitz, L., Vukovich, J., Avery, M., Brune, W., Dibb, J.E., Emmons, L., Flocke, F., Sachse, G.W., Tan, D., Shetter, R., Talbot, R.W., Streets, D.G., Frost, G. J., and Blake, D.: Improving regional ozone modeling through systematic evaluation of errors using 
the aircraft observations during the International Consortium for Atmospheric Research on Transport and Transformation, J. Geophys. Res., 112, D12S19, doi:10.1029/2006JD007762, 2007.

Mesinger, F., DiMego, G., Kalnay, E., Mitchell, K., Shafran, P. C., Ebisuzaki, W., Jovic, D., Woollen, J., Rogers, E., Berbery, E. H., Ek, M. B., Fan, Y., Grumbine, R., Higgins, W., Li, H., Lin, Y., Manikin, G., Parrish, D. and Shi, W.: North American Regional Reanalysis, B. Am. Meteorol. Soc., 87, 343-360, doi:10.1175/BAMS-87-3-343, 2006.

Moody, J. L., Felker, S. R., Wimmers, A. J., Osterman, G., Bowman, K., Thompson, A. M., and Tarasick, D. W.: A multisensor upper tropospheric ozone product (MUTOP) based on TES ozone and GOES water vapor: validation with ozonesondes, Atmos. Chem. Phys., 12, 5661-5676, doi:10.5194/acp-12-56612012, 2012.

National Research Council (NRC), global sources of local pollution-An Assessment of Long-Range Transport of Key Air Pollutants to and from the United States, 35-66, http://books. nap.edu/openbook.php?record_id $\backslash$ protect $\backslash$ kern+.1667em $\backslash$ relax $=\backslash$ protect $\backslash$ kern+.1667em $\backslash$ relax 12743 $\{\backslash \&\}$ page=35, 2009.

Nassar, R., Logan, J. A., Worden, H. M., Megretskaia, I. A., Bowman, K. W., Osterman, G. B., Thompson, A. M., Tarasick, D. W., Austin, S., Claude, H., Dubey, M. K., Hocking, W. K., Johnson, B. J., Joseph, E., Merrill, J., Morris, G., Newchurch, M., Oltmans, S.J., Posny, F., Schmidlin, F. J., Vömel, H., Whiteman, D. N., and Witte, J. C.: Validation of Tropospheric Emission Spectrometer (TES) Nadir Ozone Profiles Using Ozonesonde Measurements, J. Geophys. Res., 113, D15S17, doi:10.1029/2007JD008819, 2008.

Newman, S., Jeong, S., Fischer, M. L., Xu, X., Haman, C. L., Lefer, B., Alvarez, S., Rappenglueck, B., Kort, E. A., Andrews, A. E., Peischl, J., Gurney, K. R., Miller, C. E., and Yung, Y. L.: Diurnal tracking of anthropogenic $\mathrm{CO} 2$ emissions in the Los Angeles basin megacity during spring, 2010, Atmos. Chem. Phys. Discuss., 12, 5771-5801, doi:10.5194/acpd-12-5771-2012, 2012.

Oltmans, S. J., Lefohn, A. S., Harris, J. M., and Shadwick, D. S.: Background ozone levels of air entering the west coast of the U.S. and assessment of longer-term changes, Atmos. Environ., 42, 6020-6038, doi:10.1016/j.atmosenv.2008.03.034, 2008.

Parrish, D. D., Millet, D. B., and Goldstein, A. H.: Increasing ozone in marine boundary layer inflow at the west coasts of North America and Europe, Atmos. Chem. Phys., 9, 1303-1323, doi:10.5194/acp-9-1303-2009, 2009.

Parrish, D. D., Aikin, K. C., Oltmans, S. J., Johnson, B. J., Ives, M., and Sweeny, C.: Impact of transported background ozone inflow on summertime air quality in a California ozone exceedance area, Atmos. Chem. Phys., 10, 10093-10109, doi:10.5194/acp10-10093-2010, 2010.

Pfister, G., Thompson, A. M., Emmons, L. K., Hess, P. G., Lamarque, J.-F., and Yorks, Y. E.: Analysis of the Summer 2004 Ozone Budget over the U.S. using IONS observations and MOZART-4 simulations, J. Geophys. Res., 113, D23306, doi:10.1029/2008JD010190, 2008.

Pfister, G. G., Parrish, D. D., Worden, H., Emmons, L. K., Edwards, D. P., Wiedinmyer, C., Diskin, G. S., Huey, G., Oltmans, S. J., Thouret, V., Weinheimer, A., and Wisthaler, A.: Characterizing summertime chemical boundary conditions for airmasses entering the US West Coast, Atmos. Chem. Phys., 11, 1769-1790, doi:10.5194/acp-11-1769-2011, 2011a.
Pfister, G. G., Avise, J., Wiedinmyer, C., Edwards, D. P., Emmons, L. K., Diskin, G. D., Podolske, J., and Wisthaler, A.: CO source contribution analysis for California during ARCTASCARB, Atmos. Chem. Phys., 11, 7515-7532, doi:10.5194/acp11-7515-2011, 2011b.

Pierce, R. B., Schaack, T., Al-Saadi, J. A., Fairlie, T. D., Kittaka, C., Lingenfelser, G., Natarajan, M., Olson, J., Soja, A., Zapotocny, T., Lenzen, A., Stobie, J., Johnson, D., Avery, M. A., Sachse, G. W., Thompson, A., Cohen, R., Dibb, J. E., Crawford, J., Rault, D., Martin, R., Szykman, J., and Fishman, J.: Chemical data assimilation estimates of continental U.S. ozone and nitrogen budgets during the Intercontinental Chemical Transport Experiment-North America, J. Geophys. Res., 112, D12S21, doi:10.1029/2006JD007722, 2007.

Platnick, S., King, M.D., Ackerman, S.A., Menzel, W.P., Baum, B.A., Riedi, J.C., Frey, R.A.: The MODIS cloud products: algorithms and examples from Terra, IEEE T. Geosci. Remote, 41, 459-473, doi:10.1109/TGRS.2002.808301, 2003.

Richards, N. A. D., Osterman, G. B., Browell, E. V., Hair, J. W., Avery, M., and Li, Q.: Validation of Tropospheric Emission Spectrometer ozone profiles with aircraft observations during the Intercontinental Chemical Transport Experiment-B, J. Geophys. Res., 113, D16S29, doi:10.1029/2007JD008815, 2008.

Rodgers, C. D.: Inverse Methods for Atmospheric Sounding: Theory and Practise, World Scientific, 2000.

Russell, A. R., Perring, A. E., Valin, L. C., Bucsela, E. J., Browne, E. C., Wooldridge, P. J., and Cohen, R. C.: A high spatial resolution retrieval of $\mathrm{NO}_{2}$ column densities from OMI: method and evaluation, Atmos. Chem. Phys., 11, 8543-8554, doi:10.5194/acp-118543-2011, 2011.

Saide, P. E., Carmichael, G. R., Spak, S. N., Gallardo, L., Osses, A. E., Mena-Carrasco, M. A., and Pagowski, M.: Forecasting urban PM10 and PM2.5 pollution episodes in very stable nocturnal conditions and complex terrain using WRFChem CO tracer model, Atmos. Environ., 45, 2769-2780, doi:10.1016/j.atmosenv.2011.02.001, 2011.

Sandu, A. and Chai, T.F.: Chemical Data Assimilation an Overview, Atmosphere, 2, 426-463, doi:10.3390/atmos2030426, 2011.

Sandu, A., Daescu, D. N., Carmichael, G. R., and Chai, T.: Adjoint sensitivity analysis of regional air quality models, J. Comput. Phys., 204, 222-252, 2005.

Shindell, D. T., Faluvegi, G., Stevenson, D. S., Krol, M. C., Emmons, L. K., Lamarque, J.-F., Petron, G., Dentener, F. J., Ellingsen, K., Schultz, M. G., Wild, O., Amann, M., Atherton, C. S., Bergmann, D. J., Bey, I., Butler, T., Cofala, J., Collins, W. J., Derwent, R. G., Doherty, R. M., Drevet, J., Eskes, H. J., Fiore, A. M., Gauss, M., Hauglustaine, D. A., Horowitz, L. W., Isaksen, I. S. A., Lawrence, M. G., Montanaro, V., Mueller, J.-F., Pitari, G., Prather, M. J., Pyle, J. A., Rast, S., Rodriguez, J. M., Sanderson, M. G., Savage, N. H., Strahan, S. E., Sudo, K., Szopa, S., Unger, N., van Noije, T. P. C., Zeng, G.: Multimodel simulations of carbon monoxide: Comparison with observations and projected near-future changes, J. Geophys. Res., 111, D19306, doi:10.1029/2006JD007100, 2006.

Singh, K., Sandu, A., Bowman, K. W., Parrington, M., Jones, D. B. A., and Lee, M.: Ozone data assimilation with GEOS-Chem: a comparison between 3-D-Var, 4-D-Var, and suboptimal Kalman filter approaches, Atmos. Chem. Phys. Discuss., 11, 22247 22300, doi:10.5194/acpd-11-22247-2011, 2011. 
Singh, H. B., Cai, C., Kaduwela, A., Weinheimer, A., and Wisthaler, A.: Interactions of fire emissions and urban pollution over California: Ozone formation and air quality simulations, Atmos. Environ., 56, 45-51, doi:10.1016/j.atmosenv.2012.03.046, 2012.

Skamarock, W. C., Klemp, J. B., Dudhia, J., Gill, D., Barker, D., M., Wang, W., and Powers, J. G.: A Description of the Advanced Research WRF Version 3, http://www.mmm.ucar.edu/wrf/users/ docs/arw_v3.pdf, 2008.

Stevenson, D. S., Dentener, F. J., Schultz, M. G., Ellingsen, K., Van Noije, T. P. C., Wild, O., Zeng, G., Amann, M., Atherton, C. S., Bell, N., Bergmann, D. J., Bey, I., Butler, T., Cofala, J., Collins, W. J., Derwent, R. G., Doherty, R. M., Drevet, J., Eskes, H. J., Fiore, A., Gauss, M. A., Hauglustaine, D. A., Horowitz, L. W., Isaksen, I. S. A., Krol, M. C., Lamarque, J. F., Lawrence, M. G., Montanero, V., Müller, J. F., Pitari, G., Prather, M. J., Pyle, J. A., Rast, S., Rodriguez, J. M., Sanderson, M. G., Savage, N. H., Shindell, D. T., Strahan, S. E., Sudo, K., and Szopa, S.: Multi-model ensemble simulations of present-day and near-future tropospheric ozone, J. Geophys. Res., 111, D08301, doi:10.1029/2005JD006338, 2006.

Stith, J. L., Ramanathan, V., Cooper, W. A., Roberts, G. C., DeMott, P. J., Carmichael, G. R., Hatch, C. D., Adhikary, B., Twohy, C. H., Rogers, D. C., Baumgardner, D., Prenni, A. J., Campos, T., Gao, R., Anderson, J., and Feng, Y.: An overview of aircraft observations from the Pacific dust experiment campaign, J. Geophys. Res., 114, D05207, doi:10.1029/2008JD010924, 2009.

Tang, Y. H., Carmichael, G. R., Woo, J. H., Thongboonchoo, N., Kurata, G., Uno, I., Streets, D. G., Blake, D. R., Weber, R. J., Talbot, R. W., Kondo, Y., Singh, H. B., and Wang, T.: Influences of biomass burning during the Transport and Chemical Evolution Over the Pacific (TRACE-P) experiment identified by the regional chemical transport model, J. Geophys. Res., 108, 8824, doi:10.1029/2002JD003110, 2003.

Tang, Y., Carmichael, G., Horowitz, L., Uno, I., Woo, J.-H., Streets, D., Dabdub, D., Kurata, G., Sandu, A., Allan, J., Atlas, E., Flocke, F., Huey, L., Jakoubek, R., Millet, D., Quinn, P., Roberts, J., Worsnop, D., Goldstein, A., Donnelly, S., Schauffler, S., Stroud, V., Johnson, K., Avery, M., Singh, H., Apel, E.: Multiscale simulations of tropospheric chemistry in the eastern Pacific and on the U.S. West Coast during spring 2002, J. Geophys. Res., 109, D23S11, doi:10.1029/2004JD004513, 2004.

Tang, Y. H., Carmichael, G. R., Thongboonchoo, N., Chai, T. F., Horowitz, L. W., Pierce, R. B., Al-Saadi, J. A., Pfister, G., Vukovich, J. M., Avery, M. A., Sachse, G. W., Ryerson, T. B., Holloway, J. S., Atlas, E. L., Flocke, F. M., Weber, R. J., Huey, L. G., Dibb, J. E., Streets, D. G., and Brune, W. H.: Influence of lateral and top boundary conditions on regional air quality prediction: a multiscale study coupling regional and global chemical transport models, J. Geophys. Res., 112, D10S18, doi:10.1029/2006JD007515, 2007.

Task Force on Hemispheric Transport of Air Pollution (TF HTAP), 2010 Final Assessment report, Part A: Ozone and particulate matter, http://htap.org/publications/assessment_reports.htm, 2010.

TES L2 data user's guide, Version 5.0, http://eosweb.larc.nasa.gov/ PRODOCS/tes/UsersGuide/TES_L2_Data_Users_Guide.pdf, 2011.

The White House Office of the Press Secretary: Statement by the President on the Ozone National Ambient Air Quality Stan- dards, http://www.whitehouse.gov/the-press-office/2011/09/02/ statement-president-ozone-national-ambient-air-quality-standards, Sep. 2, 2011.

Thompson, A. M., Oltmans, S. J., Tarasick, D. W., von der Gathen, P., Smit, H. G., and Witte, J. C.: Strategic ozone sounding networks: Review of design and accomplishments, Atmos. Environ., 45, 2145-2163, doi:10.1016/j.atmosenv.2010.05.002, 2011.

US Environmental Protection Agency (US EPA): Fact Sheet: Proposal to revise the national ambient air quality standards for ozone, http://www.epa.gov/air/ozonepollution/pdfs/ fs20100106std.pdf, 2010

Veefkind, J. P.: Validation Status of the OMI Ozone Profile Product OMO3PR, Issue 1.5, June 2009.

Walker, T. W., Martin, R. V., van Donkelaar, A., Leaitch, W. R., MacDonald, A. M., Anlauf, K. G., Cohen, R. C., Bertram, T. H., Huey, L. G., Avery, M. A., Weinheimer, A. J., Flocke, F. M., Tarasick, D. W., Thompson, A. M., Streets, D. G., and Liu, X.: TransPacific transport of reactive nitrogen and ozone to Canada during spring, Atmos. Chem. Phys., 10, 8353-8372, doi:10.5194/acp10-8353-2010, 2010.

Wang, L., Newchurch, M. J., Biazar, A., Liu, X., Kuang, S., Khan, M., Chance, K.: Evaluating AURA/OMI ozone profiles using ozonesonde data and EPA surface measurements for August 2006, Atmos. Environ., 45, 5523-5530, doi:10.1016/j.atmosenv.2011.06.012, 2011.

Weiss-Penzias, P., Jaffe, D. A., Swartzendruber, P., Hafner, W., Chand, D., and Prestbo, E.: Quantifying Asian biomass burning sources of mercury using the $\mathrm{Hg} / \mathrm{CO}$ ratio in pollution plumes observed at the Mount Bachelor Observatory, Atmos. Environ., 41, 4366-4379, doi:10.1016/j.atmosenv.2007.01.058, 2007.

Wigder, N. L., Jaffe, D. A., Herron-Thorpe, F. L., and Vaughan, J. K.: Influence of Daily Variations in Baseline Ozone on Urban Air Quality in the United States Pacific Northwest, J. Geophys. Res., doi:10.1029/2012JD018738, in press, 2012.

Wild, O. and Prather, M. J.: Global tropospheric ozone modelling: Quantifying errors due to grid resolution, J. Geophys. Res., 111, D11305, doi:10.1029/2005JD006605, 2006.

Wild, O., Fiore, A. M., Shindell, D. T., Doherty, R. M., Collins, W. J., Dentener, F. J., Schultz, M. G., Gong, S., MacKenzie, I. A., Zeng, G., Hess, P., Duncan, B. N., Bergmann, D. J., Szopa, S., Jonson, J. E., Keating, T. J., and Zuber, A.: Modelling future changes in surface ozone: a parameterized approach, Atmos. Chem. Phys., 12, 2037-2054, doi:10.5194/acp-12-20372012, 2012.

Worden, J., Liu, X., Bowman, K., Chance, K., Beer, R., Eldering, A., Gunson, M., and Worden, H.: Improved tropospheric ozone profile retrievals using OMI and TES radiances, Geophys. Res. Lett., 34, L01809, doi:10.1029/2006GL027806, 2007.

Wu, L., Mallet, V., Bocquet, M., and Sportisse, B.: A comparison study of data assimilation algorithms for ozone forecasts, J. Geophys. Res., 113, D20310, doi:10.1029/2008JD009991, 2008.

Zhang, L., Jacob, D. J., Boersma, K. F., Jaffe, D. A., Olson, J. R., Bowman, K. W., Worden, J. R., Thompson, A. M., Avery, M. A., Cohen, R. C., Dibb, J. E., Flock, F. M., Fuelberg, H. E., Huey, L. G., McMillan, W. W., Singh, H. B., and Weinheimer, A. J.: Transpacific transport of ozone pollution and the effect of recent Asian emission increases on air quality in North America: an integrated analysis using satellite, aircraft, ozonesonde, and surface observations, Atmos. Chem. Phys., 8, 6117-6136, 
doi:10.5194/acp-8-6117-2008, 2008.

Zhang, L., Jacob, D. J., Kopacz, M., Henze, D. K., Singh, K., and Jaffe, D. A.: Intercontinental source attribution of ozone pollution at western U.S. sites using an adjoint method, Geophys. Res. Lett., 36, L11810, doi:10.1029/2009GL037950, 2009.

Zhang, L., Jacob, D. J., Downey, N. V., Wood, D. A., D. Blewitt, Carouge, C. C., van Donkelaar, A., Jones, D.B.A., Murray, L. T., Wang, Y.: Improved estimate of the policyrelevant background ozone in the United States using the GEOS-Chem global model with $1 / 2^{\circ} \times 2 / 3^{\circ}$ horizontal resolution over North America, Atmos. Environ., 45, 6769-6776, doi:10.1016/j.atmosenv.2011.07.054, 2011.
Zhu, C., Byrd, R. H., Lu, P., and Nocedal, J.: L-BFGS-B-fortran routines for large scale bound constrained optimization, ACM T. Math. Software, 23, 550-560, doi:10.1145/279232.279236, 1997.

Zoogman, P., Jacob, D.J., Chance, K., Zhang, L., Le Sager, P., Fiore, A.M., Eldering, A., Liu, X., Natraj, V., and Kulawik, S.S.: Ozone Air Quality Measurement Requirements for a Geostationary Satellite Mission, Atmos. Environ., 45, 7143-7150, doi:10.1016/j.atmosenv.2011.05.058, 2011. 